\title{
INTEGRATED POWER GENERATION SYSTEMS FOR COAL MINE WASTE METHANE UTILIZATION
}

\author{
PHASE III FINAL REPORT
}

APRIL 25，2001 - OCTOBER 4, 2004

Peet M. Sööt

Dale R. Jesse

Michael E. Smith

August, 2005

Contract No. DE-FC26-01NT40980

\author{
For: \\ U.S. Department of Energy \\ National Energy Technology laboratory \\ Morgantown, West Virginia
}

By:

Northwest Fuel Development, Inc. 4064 Orchard Drive

Lake Oswego, OR 97035 


\section{DISCLAIMER}

This report was prepared as an account of work sponsored by an agency of the United States Government. Neither the United States Government nor any agency thereof, nor any of their employees, makes any warranty, express or implied, or assumes any legal liability or responsibility for the accuracy, completeness, or usefulness of any information, apparatus, product, or process disclosed, or represents that its use would not infringe privately owned rights. Reference herein to any specific commercial product, process, or service by trade name, trademark, manufacturer, or otherwise does not necessarily constitute or imply its endorsement, recommendation, or favoring by the United States Government or any agency thereof. The views and opinions of authors expressed herein do not necessarily state or reflect those of the United States Government or any agency thereof.

Available to the public from the National Technical Information Service, U.S. Department of Commerce, 5285 port Royal Road, Springfield, VA 22161; phone orders accepted at (703) 487-4650. 


\section{ABSTRACT}

An integrated system to utilize the waste coal mine methane (CMM) at the Federal No. 2 Coal Mine in West Virginia was designed and built. The system includes power generation, using internal combustion engines, along with gas processing equipment to upgrade sub-quality waste methane to pipeline quality standards. The power generation has a nominal capacity of $1,200 \mathrm{kw}$ and the gas processing system can treat about 1 million cubic feet per day (1 MMCFD) of gas. The gas processing is based on the Northwest Fuel Development, Inc. (NW Fuel) proprietary continuous pressure swing adsorption (CPSA) process that can remove nitrogen from CMM streams.

The two major components of the integrated system are synergistic. The byproduct gas stream from the gas processing equipment can be used as fuel for the power generating equipment. In return, the power generating equipment provides the nominal power requirements of the gas processing equipment.

This Phase III effort followed Phase I, which was comprised of a feasibility study for the project, and Phase II, where the final design for the commercial-scale demonstration was completed. The fact that NW Fuel is desirous of continuing to operate the equipment on a commercial basis provides the validation for having advanced the project through all of these phases.

The limitation experienced by the project during Phase III was that the CMM available to operate the CPSA system on a commercial basis was not of sufficiently high quality. NW Fuel's CPSA process is limited in its applicability, requiring a relatively high quality of gas as the feed to the process. The CPSA process was demonstrated during Phase III for a limited time, during which the processing capabilities met the expected results, but the process was never capable of providing pipeline quality gas from the available low quality CMM. The NW Fuel CPSA process is a low-cost "polishing unit" capable of removing a few percent nitrogen. It was never intended to process CMM streams containing high levels of nitrogen, as is now the case at the Federal No.2 Mine.

Even lacking the CPSA pipeline delivery demonstration, the project was successful in laying the groundwork for future commercial applications of the integrated system. This operation can still provide a guide for other coal mines which need options for utilization of their methane resources. The designed system can be used as a complete template, or individual components of the system can be segregated and utilized separately at other mines.

The use of the CMM not only provides an energy fuel from an otherwise wasted resource, but it also yields an environmental benefit by reducing greenhouse gas emissions. The methane has twenty times the greenhouse effect as compared to carbon dioxide, which the combustion of the methane generates. The net greenhouse gas emission mitigation is substantial. 
Title Page

i

Disclaimer

i i

Abstract

iii

Table of Contents

$i v$

List of Exhibits

vi

I. EXECUTIVE SUMMARY 1

II. INTRODUCTION 2

A. Site Information 2

B. Mining Overview 5

C. Methane Drainage and Utilization $r$

D. Coal Characteristics 5

III. RESULTS AND DISCUSSION 7

A. Federal No. 2 Mine Gas Availability 7

1. Historical Methane Emissions 7

a. Air Shaft Emissions 7

b. Gob Vent Holes 7

2. Project Methane Emissions 9

a. Air Shaft Emissions 9

b. Gob Gas Vent Holes 9

(1). Gob Vent Blower Tests - $1996 \quad 15$

(2). Gob Vent Blower Tests - $1998 \quad 17$

B. Federal No. 2 Methane Resource/Reserve 21

1. Coal Seam Gas Resources 21

2. Oil and Gas Well Contribution 23

3. Other Potential Sources 24

4. Methane Resource Estimate from Mine Emissions 28

5. Resource Conclusions 30

6. Phase III Results 30

C. Technology Application $\quad 31$

1. Comprehensive Plan 31

2. Development Strategy 34

3. Fuel Supply 35

4. Generating Equipment 41

a. Siting Logistics/Site Development 41

b. Internal Combustion Engine Prime Movers 41

c. Electrical 43

d. Exhaust 49

e. Air Shaft Emissions for Combustion Air 49

5. Gas Processing 53

a. Nitrogen Rejection Units (NRU) 53

(1). Pressure Swing Adsorption (PSA) 53

(2). Continuous PSA (CPSA) 54

b. Carbon Dioxide Removal 54

c. Dehydration $\quad 55$ 


\section{TABLE OF CONTENTS}

(Continued)

D. Phase II Operating Results $\quad 55$

1. Power Generation $\quad 55$

2. Nitrogen Rejection - CPSA 58

E. Economic Analysis $\quad 60$

1. Federal No. 2 Mine Electricity Rates 60

2. Power Generation Equipment Capital Costs 61

3. Power Generating $O \&$ M Costs 61

4. Gas Processing Capital Costs 61

5. Gas Processing Operating and Maintenance Costs 61

6. Discounted Cash Flow Analysis 61

F. Permitting 63

1. Federal Energy Regulatory Commission (FERC) 63

2. Air Emissions Permits 63

3. Gas Well Permits 63

4. Land Ownership Review 64

IV. CONCLUSIONS $\quad 64$

V. REFERENCES

VI. LIST OF ACRONYMS AND ABBREVIATIONS 68

\section{APPENDICES}

A. Pittsburgh Coal Seam Geology 69

B. Gob Vent Blower Tests - $1998 \quad 84$

C. Power Generation Capital Cost Detail 87

D. Source Emission Tests: $\mathrm{NO}_{\mathrm{x}}$ and $\mathrm{CO} 94$ 


\section{LIST OF EXHIBITS}

\begin{tabular}{|c|c|c|}
\hline & & Page \\
\hline EXHIBIT & 1. Project Site - Federal No. 2 Mine & 3 \\
\hline EXHIBIT & 2. Mines in the Pittsburgh Coal seam & 4 \\
\hline EXHIBIT & 3. Federal No. 2 Mine Coal Production & 6 \\
\hline EXHIBIT & 4. Federal No. 2 Mine Air Shaft Methane Emissions & 8 \\
\hline EXHIBIT & 5. Gob Gas Vent Data - Federal No. 2 Mine 1990/91 & 10 \\
\hline EXHIBIT & 6. Federal No. 2 mine Air shaft Methane Liberations & 11 \\
\hline EXHIBIT & 7. Project Primary Area & 12 \\
\hline EXHIBIT & 8. Gob Vent Hole Locations & 13 \\
\hline EXHIBIT & 9. Gob Gas Vent Data Federal No. 2 Mine 1995 & 14 \\
\hline EXHIBIT & 10. Gob Vent Blower Test Results - (9/96) & 16 \\
\hline EXHIBIT & 11. Vent \#29 Pressure Recovery - A & 18 \\
\hline EXHIBIT & 12. Vent \#29 Pressure Recovery - B & 19 \\
\hline EXHIBIT & 13. Vent \#29 Flow Potential & 20 \\
\hline EXHIBIT & 14. Coal and Gas Resources - Federal No. 2 Mine & 22 \\
\hline EXHIBIT & 15. Federal No. 2 Mine - Northeast Quadrant & 25 \\
\hline EXHIBIT & 16. Methane Flow Rate: & \\
\hline & Left Air Course, Northeast Quadrant & 26 \\
\hline EXHIBIT & 17. Methane Flow Rate: & \\
\hline & Right Air Course, Northeast Quadrant & 27 \\
\hline EXHIBIT & 18. Predicted Mine Methane Emissions & 29 \\
\hline EXHIBIT & 19. Waste Methane Utilization Systems Schematic & 32 \\
\hline EXHIBIT & 20. Gob Gas Gathering system - Surface Routing & 36 \\
\hline EXHIBIT & 21. Pipeline Schematic - Pressure Profile & 37 \\
\hline EXHIBIT & 22. Vent \#29 Wellhead Configuration & 38 \\
\hline EXHIBIT & 23. Vent \#30 Wellhead Configuration & 39 \\
\hline EXHIBIT & 24. On Site Fuel Supply System & 40 \\
\hline EXHIBIT & 25. Generator Site Layout & 42 \\
\hline EXHIBIT & 26. Engine/Genset Layout & 44 \\
\hline EXHIBIT & 27. Engine Control System & 45 \\
\hline EXHIBIT & 28. Protective Relay One-Line Diagram & 46 \\
\hline EXHIBIT & 29. Layout for Estimating Wire Requirements & 47 \\
\hline EXHIBIT & 30. Generator Electrical Controls & 48 \\
\hline EXHIBIT & 31. Exhaust Stack Design & 50 \\
\hline EXHIBIT & 32. Exhaust Gathering Line Design & 51 \\
\hline EXHIBIT & 33. Piping/Equipment for Combustion Air & 52 \\
\hline EXHIBIT & 34. PSA Process Diagram & 54 \\
\hline EXHIBIT & 35. CPSA Process Diagram & 56 \\
\hline EXHIBIT & 36. Phase III Power Generation & 57 \\
\hline EXHIBIT & 37. CPSA Test Results & 59 \\
\hline EXHIBIT & 38. Power Generation Capital Costs & 62 \\
\hline
\end{tabular}




\section{EXECUTIVE SUMMARY}

Northwest Fuel Development, Inc. (NW Fuel) confirmed the technical and economic viability for utilizing coal mine methane (CMM) at the Federal No. 2 Mine during Phases I and II of this project. This Mine in northern West Virginia already had a program to capture pipeline quality gas and deliver it to a natural gas pipeline. The NW Fuel project used sub-quality CMM from the Mine. The project utilized the sub-quality gas directly in power generation and was to upgrade some gas that was nearly pipeline quality for delivery of that gas to a natural gas pipeline. The proposed project was to complement the existing activities and capture additional methane which would otherwise be emitted into the atmosphere. This was a logical project for this Mine. The Federal No. 2 Mine has a history of applying innovative methane drainage techniques to improve the safety and productivity of the mining operations.

The proposed project was to capture a significant amount of the non-pipeline quality methane which was being released from gob gas vent holes. The power generating component of the project utilized methane from gob vent holes in the southern part of the Mine - the Project Area. Two segments of the southern part of the Mine were sealed during the execution of Phase III of the Project. It was expected that this would enhance the potential fuel supply as the ventilation air would no longer be circulated in these areas. That was not the case in the first sealed area. The methane concentration in that area has not risen over $14 \%$ methane, even though it has been sealed for several years. Fortunately, the concentration of methane in the second sealed area exceeded $60 \%$ within months of the sealing.

The prior design effort showed that there are adequate gas resources in the Project Area. The Project Area contains over $4 \times 10^{5} \mathrm{~m}^{3}(20 \mathrm{BCF})$ of gas for future. This would be enough fuel to support an order of magnitude more electric power generation than was installed for the current one (1) MW project.

The equipment was all installed at the site of the formerly active Parrish Shaft. The generating units were located at this central location in order to expedite operation and maintenance of the facility. Gas was brought to the site from gob wells that were 0.25 to 1.2 miles away. This gas supplemented with an on site gas source. A substation for delivering the generated electricity had been originally placed at that location for operating the fan at the Parrish Shaft. Eastern Associated Coal Corp. (EACC) purchased all of the generated electricity from the equipment under a letter agreement with NW Fuel. The project only needed to install a transformer at the Parrish Shaft to raise the generated 480 volts to 4160 volts, so it could be delivered to EACC.

There was 5.6 million kWh of electricity generated during two years of the Phase III operation. More would have been generated, but the gob wells did not provide the amounts of gas that Phase II testing indicated they would. Only after the on-site grout vent pipe provided supplemental fuel were the generators able to produce more than a few hundred kilowatts (kW).

A new installation of this project may not be economically viable. This is due to the current low electric rates being paid by mine operators and the higherthan-expected operating costs. Once the local operators become more conversant with the equipment they will be able to manage the equipment without the expense of sending managers to the site for direct supervision. That will likely allow such an installation to provide a decent rate of return. 
The CPSA equipment would have allowed for the delivery of pipeline quality gas from this project, had the feed gas been available at the Phase II quality levels. This installation would have paid out an after-tax return of $20 \%$ to 35\%. The byproduct stream from the NRU was to be used to fuel the power generators. This would have allowed the best matching of gas stream quality to the utilization technology.

This was to be the first-of-a-kind waste methane project. Sub-quality gas would be upgraded for pipeline delivery. The byproduct stream from the gas processing was to be used for power generation, with supplemental fuel coming from lower quality gas from gob wells. Combustion air for the power generation was to come from the air shaft emissions from the Mine.

Even with the shortfalls in the total system integration, the techniques developed at this site are still applicable to the many other mines operating in the Pittsburgh coalbed and readily adaptable to mines in other coal seams throughout the US and foreign countries.

\section{INTRODUCTION}

\section{A. Site Information}

This coal mine methane project was developed at the Federal No. 2 Mine in northern West Virginia. The Mine is owned and operated by Eastern Associated Coal Corp. (EACC). EACC is a subsidiary of Peabody Holding Company, Inc. $(\mathrm{PHC})$. These Companies have shown a continual commitment to methane capture and utilization at this Mine. There was already one commercial operation which captured pipeline quality methane from gob vent holes at the Mine. That gas was delivered to a natural gas pipeline. This project is owned and operated by Dominion Exploration and Production, Inc. (DEPI). Since there were additional methane sources available for utilization, PHC initiated the current project in an attempt to capture that methane and put it to commercial use. Northwest Fuel Development, Inc. (NW Fuel) became a co-sponsor of the project with its experience in coal mine methane recovery and utilization.

The Mine location in northern West Virginia is depicted in Exhibit 1. This Mine formerly had an active shaft portal located at 39 40' $30^{\prime \prime} 1$ atitude, $80^{\circ}$ 19' 0" longitude. Mining operations are in the Pittsburgh Coal Seam, which is purported to be the largest single coal seam in the US. The Federal No. 2 Mine is surrounded on three sides by other mines which are active in the Pittsburgh Seam, as shown in Exhibit 2. The Pittsburgh seam dips towards the east in this area and there is still virgin coal on the west flank of the Mine.

Gas rights on various parcels within the Mine boundary are leased to a number of different companies, including EACC, Equitable, Carnegie, Hope, and Pennzoil. Not all oil and gas rights are leased, and NW Fuel acquired key gas leases, which were required for the project.

There are 5 pipelines which traverse the property. These lines were owned by Hope $\left(15 \mathrm{~cm}\right.$ and $25 \mathrm{~cm} / 6 "$ and $\left.10^{\prime \prime}\right)$, Carnegie $\left(30 \mathrm{~cm} / 12^{\prime \prime}\right)$ and Equitable $(30 \mathrm{~cm}$ and $40 \mathrm{~cm} / 12 "$ and 16") (TRW). The Hope Natural Gas pipelines have been sold to Eastern States Oil and Gas. One of those lines is within a hundred yards of the Parrish Shaft. That would have made the proposed natural gas sales quite easy. 
EXHIBIT 1. Project Site - Federal No. 2

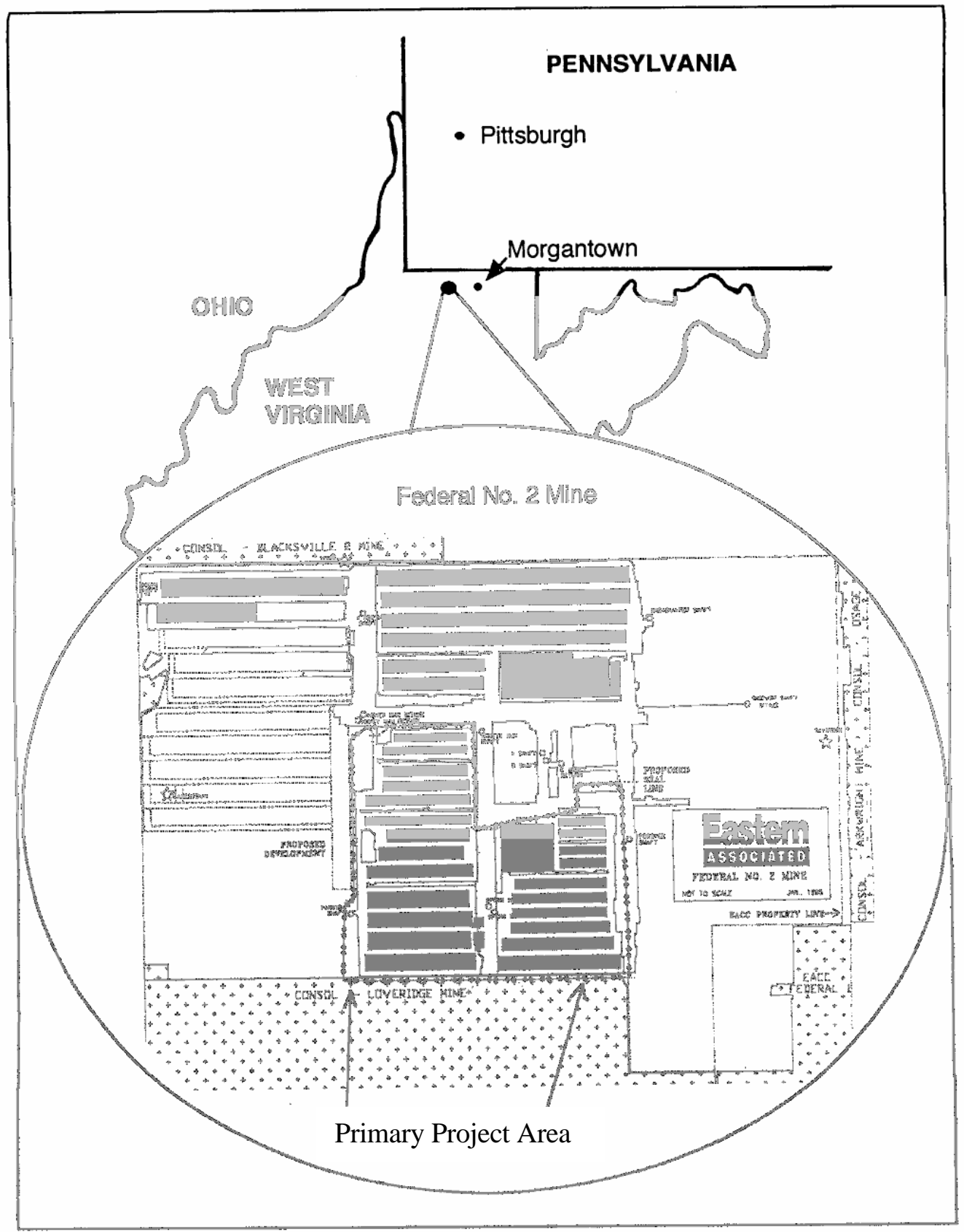


EXHIBIT 2. Mines in the Pittsburgh Coal Seam

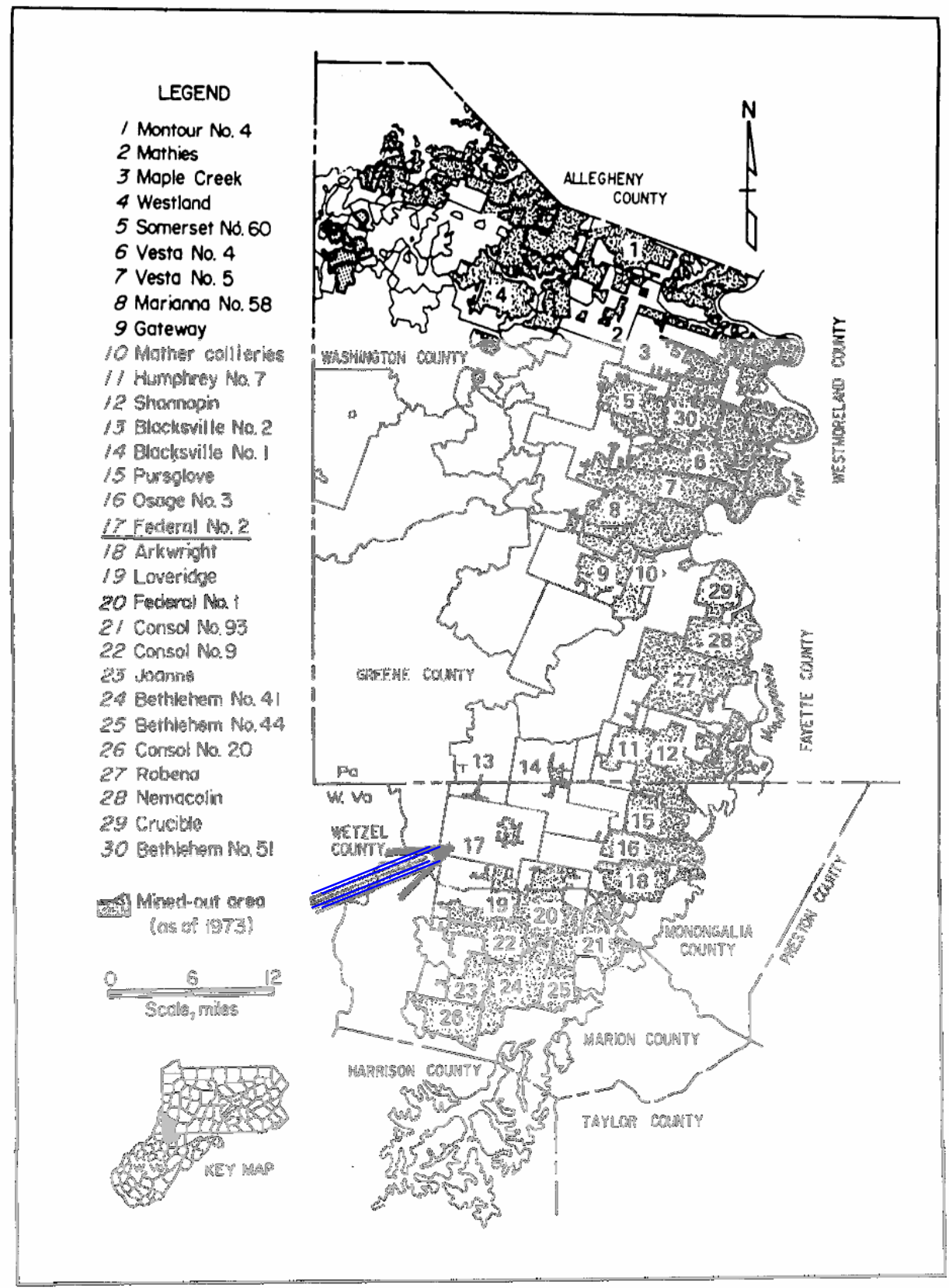




\section{B. Mining Overview}

The Federal No. 2 Mine began production in 1967, originally using continuous mining techniques and later developing longwalls (Ulery and Molinda). Early entries were driven by a tunnel boring machine but most now are driven by continuous-mining machines. The longwall operation is now producing from "super" longwall panels. The Mine is operating at a depth of $240 \mathrm{~m}$ (800 feet) in the Pittsburgh Coalbed.

Yearly coal production has generally risen quite consistently. It was producing about one million metric tons per year (MMmtpy) in the early 70's and was yielding over 4 MMmtpy at the beginning of the current project (see Exhibit 3). Nearly $60 \mathrm{MM}$ metric tons of coal have been removed from the Mine during its 28 years of active mining.

\section{Methane Drainage and Utilization}

The current DEPI commercial project is not the first attempt at methane capture at the Federal No. 2 Mine. There were even commercial sales of coalbed methane from this Mine in the 1970's. The Federal No. 2 Mine has an extensive history of testing novel techniques for coal degasification and gas utilization: (a) virgin coal has been degassed at two sites using horizontal boreholes, (b) small vertical boreholes have been tested for advance degas of coals, and (c) directional drilling has been performed for advanced degasification. Additionally, isolation techniques have been used to degas coal panels prior to mining.

\section{Coal Characteristics}

In developing the proposed project, it was important to understand the coals which occur in the area of the Mine. In addition the Pittsburgh Seam, which is being mined, there are overlying and underlying seams which contribute gas to the mine ventilation system. A general study of the coal characteristics was made in Phase I of this project. This included a review of published

literature relating to West Virginia coals in general and the Monongalia County coals in particular. A synopsis of this background study is presented in Appendix A. It includes sections on Pittsburgh coal characteristics, local geology (stratigraphy and structure), in-situ coalbed pressures, and coal permeability.

An important element of this study confirmed the gas migration characteristics of the Pittsburgh seam coal. The blocky nature of this coal results in extremely long gas adsorption and desorption times. Complete desorption can take 60 to 600 days according to Hunt and Steele. Hence, the Pittsburgh coal that is left behind during mining would desorb methane for years after the adjacent coal is removed. That has been confirmed through observations of the gob wells which were targeted for use in the proposed project. 
EXHIBIT 3. Federal No. 2 Mine Coal Production

\begin{tabular}{lcc} 
& Milions of Tons Per Year \\
\cline { 2 - 3 } Year & $\begin{array}{c}\text { (metric) } \\
\text { MMmtpy } \\
1980\end{array}$ & $\begin{array}{c}\text { (short) } \\
\text { MMTPY }\end{array}$ \\
1985 & 2.35 & 1.514 \\
1990 & 3.82 & 2.588 \\
1991 & 3.99 & 4.198 \\
1992 & 3.92 & 4.391 \\
1993 & 1.19 & 4.317 \\
1994 & 3.70 & 1.311 \\
1995 & 3.91 & 4.067 \\
1996 & 4.18 & 4.30
\end{tabular}


III. RESULTS AND DISCUSSION

\section{A. Federal No. 2 Mine Gas Availability}

\section{Historical Methane Emissions}

Considerable data are available regarding the historical methane emissions at the Federal No. 2 Mine. These consist of measurements for both ventilation air methane and gob vent hole emissions. Some of the data have been published while others have been developed through private funding and are held as proprietary.

\section{a. Air Shaft Emissions}

The air shaft methane emissions for US coal mines have been surveyed and published for many years (Irani et al, Grau and LaScola, and Grau). The US Bureau of Mines compiled data from the Mine Safety and Health Administration (MSHA) in order to publish the surveys. In 1985, the Mine emitted $180 \mathrm{~m}^{3} / \mathrm{min}$ (9.2 MMCFD) of methane from its air shafts (Grau).

More recent data from MSHA are compiled by the US EPA. Those data show the Federal Mine emissions increased to over $270 \mathrm{~m}^{3} / \mathrm{min}$ (14 MMCFD) in 1995 and 1996.

It is useful to try and correlate the methane emissions from the Mine with the coal production rate. A number of authors have pointed out the possibility of such correlations (Irani and Kissell, Kissell et al, and TRW). As can be seen in Exhibit 4, the Federal No. 2 Mine generally produces between 40 to $60 \mathrm{~m}^{3} / \mathrm{mt}$ (1000 and $2000 \mathrm{CF} / \mathrm{ton}$ ) coal that is mined. This ratio is considerably higher only in years of low coal production. Other mines in the Pittsburgh Seam have comparable methane emission ratios (Irani et al, Grau and LaScola, and Grau).

Since the Pittsburgh Seam only contains about $8 \mathrm{~m}^{3} / \mathrm{mt}(200$ cubic feet of methane per ton), there must be other sources of methane that contribute to the methane loading in the air ventilation stream. Even if one doubles the Pittsburgh Seam methane content (to account for the $40 \%$ of coal which is left behind in the Mine and which can release methane into the ventilation air) there is still a major portion of the emitted methane whose source has not been identified. This methane comes from the overlying and underlying coal seams which are not mined. These coal seams may be fractured by the movement of surrounding strata as the Pittsburgh seam is mined and subsidence occurs. The additional methane could also come from other types of geologic strata, such as shales or sandstones, which could be sources or reservoirs of methane. Even gas and oil wells drilled to deeper strata could be the conduit for methane into the mining area. The methane emission ratio in Exhibit 4 accounts for all of these sources, including the gas from the Pittsburgh seam.

\section{b. Gob Vent Holes}

There is another source of methane emissions at the Federal No. 2 Mine that $s$ not included in the aforementioned emissions values. The gob vent holes, which are drilled in advance of longwall mining, produce methane after the longwall machine has passed under the vent hole. These are drilled through the overlying coal seams and do not penetrate into the Pittsburgh Seam. The gob vent hole emissions are considerably lower than the air shaft emissions, but they are significantly more concentrated. It was estimated that the gob vent holes at this Mine could have produced as much as $30 \mathrm{~m}^{3} / \mathrm{min}$ ( 1.5 MMCFD) of methane in 1987 (Sööt, 1990). This was based on analogies with other mines 
EXHIBIT 4. Federal No. 2 Mine Air Shaft Methane Emissions

\begin{tabular}{|c|c|c|c|c|c|c|}
\hline & & & $\operatorname{Pr}$ & ion, & $\begin{array}{r}\text { Me } \\
\text { Emiss }\end{array}$ & atio, \\
\hline & $\mathrm{m}^{3} / \mathrm{min}$ & MMCFD & MMTPY & MMmtpy & $\mathrm{SCF} / \mathrm{Ton}$ & $\mathrm{m}^{3} / \mathrm{mt}$ \\
\hline 1971 & 160 & 8.1 & 1.72 & 1.56 & 1720 & 54 \\
\hline 1973 & 130 & 6.7 & 0.74 & 0.67 & 3310 & 100 \\
\hline 1975 & 160 & 8.1 & 0.94 & 0.85 & 3150 & 99 \\
\hline 1980 & 150 & 7.6 & 1.51 & 1.37 & 1830 & 58 \\
\hline 1985 & 180 & 9.2 & 2.59 & 2.35 & 1300 & 40 \\
\hline 1996 & 280 & 14.3 & 4.60 & 4.18 & 1130 & 35 \\
\hline & & & & age & $1500 *$ & $47 *$ \\
\hline
\end{tabular}


operating in the Pittsburgh Seam. From actual data, which were acquired more recently, it has become evident that the gob vent holes produce less than 10 $\mathrm{m}^{3} / \mathrm{min}$ ( 1 MMCFD) .

The field data for historic gob gas emissions came from surveys of the vent holes by CNG Producing Company (CNGP) in 1990 and 1991. The results of these surveys are presented in Exhibit 5. The aggregate emissions from the 28 vent holes which were surveyed were about 500 MCFD of methane. As a result of these surveys, CNGP initiated the commercial project which now gathers pipeline quality gas from vent holes in the northern part of the Mine. (CNGP was sold to Dominion since the initiation of this project.) This gas is delivered into a nearby natural gas pipeline.

\section{Project Methane Emissions}

In order to provide the basis for the present project, more data were acquired regarding the methane emissions from the Federal No. 2 Mine.

\section{a. Air Shaft Emissions}

The Mine personnel provided methane emission data for all of the air shafts at the Mine. These are tabulated in Exhibit 6. The two shafts/Fans of greatest interest were the Parrish and Spens Fans. These were closest to the original area of interest, as shown in Exhibit 7. Of these two shafts, the Parrish Shaft is of more interest, since the methane concentration is higher. The 0.7\% at that shaft is considerably higher than the 0.17\% at the Spens Shaft. These results are consistent with data which NW Fuel obtained from MSHA in 1991 . At that time the spens Shaft emissions were at $0.14 \%$ and the Parrish Shaft was emitting air with $0.9 \%$ methane. These concentrations are important for the use of the air as combustion air in a gas turbine.

\section{b. Gob Gas Vent Holes}

The methane from the gob gas vent holes in the northern end of the Mine is all currently being captured by CNGP for delivery to a natural gas pipeline. The total deliveries by CNGP are $10 \mathrm{~m}^{3} / \mathrm{min}$ (500 MCFD). The production from those individual vent holes were not surveyed.

The remaining gob vent holes, which emit methane into the air, are in the southern part of the Mine. These are in the Primary Project Area outlined in Exhibit 1 (see page 3 ).

The locations of the individual vent holes in this Area are shown in Exhibit 8 . There were one to three vent holes drilled into each longwall panel. The results from the Phase I survey of these gob gas vent holes is presented in Exhibit 9. It is fortuitous that the best vent holes, \#21 and \#29, were close to the Parrish Shaft. These Vents provided the highest quality gas and the best flow rates. Vent \#30 was observed to also be producing significant amounts of methane. The pipe was cut down during Phase II and measurements taken. The aggregate methane production from the measured vent holes in the 1995 survey was about $4 \mathrm{~m}^{3} / \mathrm{min}$ (200 MCFD). This is enough to fire about $600 \mathrm{kw}$ of electrical generating capacity. There was little doubt that additional flow could be generated from the vents as was proved through blower tests which were performed during Phase II. 
EXHIBIT 5. Gob Gas Vent Data - Federal No. 2 Mine 1990/1991

\begin{tabular}{|c|c|c|c|c|c|c|c|c|c|c|c|c|}
\hline $\begin{array}{l}\text { GOB } \\
\text { GAS } \\
\text { VENT \# }\end{array}$ & DATE & $\begin{array}{l}\mathrm{CH} 4 \\
\mathrm{Vol} \%\end{array}$ & $\begin{array}{l}\mathrm{CO} 2 \\
\text { Vol \% } \\
\end{array}$ & $\begin{array}{l}\text { N2 } \\
\text { Vol \% }\end{array}$ & $\begin{array}{l}\mathrm{H} 2 \mathrm{~S} \\
\mathrm{ppm}\end{array}$ & $\frac{\text { Reported }}{\mathrm{m} 3 / \mathrm{hr}}$ & $\frac{\text { Flow }}{\text { MCFD }}$ & $\begin{array}{r}\text { USBM } \\
\text { Method } \\
\text { Factor } \\
\end{array}$ & $\begin{array}{r}\text { Gas } \\
\text { Flow, } \\
\text { m3/hr } \\
\end{array}$ & $\begin{array}{r}\text { Gas } \\
\text { Flow, } \\
\text { MCFD } \\
\end{array}$ & $\begin{array}{r}\mathrm{CH} 4 \\
\text { Flow, } \\
\text { m3/hr } \\
\end{array}$ & $\begin{array}{r}\mathrm{CH} 4 \\
\text { Flow, } \\
\text { MCFD } \\
\end{array}$ \\
\hline 5 & $\overline{5 / 24 / 90}$ & & & & & & 0 & & & & & \\
\hline 6 & $5 / 24 / 90$ & 93.6 & 1.9 & 3.4 & 0 & 7 & 6 & 0.69 & 5 & 34 & 5 & \\
\hline 7 & $5 / 24 / 90$ & \multicolumn{11}{|c|}{ Intake } \\
\hline 8 & $5 / 24 / 90$ & 94.8 & 1.5 & 3.4 & 0 & 77 & 65 & 0.73 & 60 & 4,174 & 57 & 3,957 \\
\hline 9 & $5 / 24 / 90$ & 97.3 & 1.3 & 1.1 & 1.7 & 136 & 115 & 0.73 & 106 & 13,065 & 103 & 12,712 \\
\hline 10 & $5 / 24 / 90$ & 90.2 & 1.6 & 7.7 & 0 & 28 & 24 & 0.69 & 21 & 538 & 19 & 485 \\
\hline 11 & $5 / 24 / 90$ & 92.7 & 1.2 & 2.2 & 0.6 & 66 & 56 & 0.71 & 50 & 3,013 & 47 & 2,793 \\
\hline 11 & $12 / 11 / 91$ & 91.9 & 1.6 & 5.2 & 0 & 34 & 29 & 0.71 & 26 & 808 & 24 & 743 \\
\hline 12 & $5 / 24 / 90$ & 94.5 & 1.6 & 3.4 & 0 & 39 & 33 & 0.71 & 30 & 1,046 & 28 & 989 \\
\hline 13 & $6 / 6 / 90$ & \multicolumn{11}{|c|}{ Intake } \\
\hline 14 & 6/6/90 & \multicolumn{11}{|c|}{ Intake } \\
\hline 15 & 6/6/90 & 42.2 & 0.8 & 56.2 & 0 & 47 & 40 & 0.72 & 36 & 1,559 & 15 & 658 \\
\hline 15 & $12 / 11 / 91$ & 70.7 & 1.1 & 27.9 & 0 & 19 & 16 & 0.72 & 15 & 249 & 10 & 17 \\
\hline $15 \mathrm{~A}$ & $6 / 6 / 90$ & \multicolumn{11}{|c|}{ Intake } \\
\hline 16 & 6/6/90 & \multicolumn{11}{|c|}{ Intake } \\
\hline 17 & $6 / 6 / 90$ & \multicolumn{11}{|c|}{ Intake } \\
\hline 18 & 6/6/90 & \multicolumn{11}{|c|}{ Intake } \\
\hline 19 & $6 / 6 / 90$ & \multicolumn{11}{|c|}{0} \\
\hline 20 & 6/6/90 & \multicolumn{11}{|c|}{$\begin{array}{r}0 \\
96\end{array}$} \\
\hline 21 & $6 / 6 / 90$ & 93.5 & 3.7 & 2.1 & 15 & 113 & 96 & 0.72 & 87 & 8,980 & 82 & 8,396 \\
\hline 21 & $2 / 26 / 91$ & 93 & 3.8 & 2.4 & 6 & 76 & 64 & 0.72 & 58 & 3,991 & 54 & 3,712 \\
\hline 21 & $12 / 11 / 91$ & 93 & 3.7 & 2.4 & 30 & 51 & 43 & 0.72 & 39 & 1,802 & 36 & 1,67 \\
\hline 22 & $6 / 6 / 90$ & \multicolumn{11}{|c|}{0} \\
\hline 23 & $6 / 6 / 90$ & \multicolumn{11}{|c|}{0} \\
\hline 24 & $6 / 6 / 90$ & 73.5 & 1.2 & 25 & 0 & 53 & 45 & 0.72 & 41 & 1,973 & 30 & 1,450 \\
\hline 24 & $12 / 11 / 91$ & 71.7 & 2 & 26 & 0 & 34 & 29 & 0.72 & 26 & 819 & 19 & 588 \\
\hline 25 & $6 / 6 / 90$ & 85.7 & 1.6 & 12.4 & 0 & 95 & 80 & 0.72 & 73 & 6,236 & 62 & 5,34 \\
\hline 25 & $12 / 11 / 91$ & 87.8 & 2.1 & 9.8 & 0 & 45 & 38 & 0.72 & 35 & 1,407 & 30 & 1,235 \\
\hline 26 & 6/6/90 & 96 & 0.9 & 1.8 & 0.4 & 30 & 25 & 0.72 & 23 & 609 & 22 & 58 \\
\hline 26 & $12 / 11 / 91$ & 97.7 & 0.8 & 0.7 & 0.2 & 18 & 15 & 0.72 & 14 & 219 & 13 & 21 \\
\hline 27 & 6/6/90 & \multicolumn{11}{|c|}{0} \\
\hline 27 & $12 / 11 / 91$ & \multicolumn{11}{|c|}{ Intake } \\
\hline 28 & $6 / 6 / 90$ & \multicolumn{11}{|c|}{ Intake } \\
\hline 29 & $6 / 6 / 90$ & 96.8 & 1 & 1.7 & 1.5 & 157 & 133 & 0.72 & 121 & 17,235 & 117 & 16,68 \\
\hline 29 & $2 / 26 / 91$ & 93.8 & 1.7 & 4 & 30 & 85 & 72 & 0.72 & 66 & 5,051 & 61 & 4,73 \\
\hline 29 & $12 / 11 / 91$ & 93.6 & 2.4 & 3.5 & 8 & 59 & 50 & 0.72 & 46 & 2,436 & 43 & 2,28 \\
\hline 30 & $6 / 6 / 90$ & \multirow{3}{*}{\multicolumn{11}{|c|}{$\begin{array}{l}\text { Producing } \\
\text { Intake } \\
\quad 0\end{array}$}} \\
\hline 30 & $2 / 26 / 91$ & & & & & & & & & & & \\
\hline 31 & $6 / 6 / 90$ & & & & & & & & & & & \\
\hline
\end{tabular}

FED/GOB Gas Vent 1990/91 
EXHIBIT 6. Federal No. Mine Methane Liberation

\begin{tabular}{lrrrrrr} 
& Quantity & Quantity & CH4 & \multicolumn{2}{c}{$\begin{array}{c}\text { Methane } \\
\text { Liberation }\end{array}$} \\
Fan & $\underline{\mathrm{cfm}}$ & $\underline{\mathrm{m} 3 / \mathrm{hr}}$ & $\underline{\mathrm{m}}$ & $\mathrm{m} / \mathrm{hr}$ & $\underline{\mathrm{MMCFD}}$ \\
Broadwater & 203,888 & 346,610 & $1.18 \%$ & 4,090 & $3,464,640$ \\
Scott's Run & 350,092 & 595,156 & $0.10 \%$ & 595 & 504,000 \\
C-Shaft & 433,350 & 736,695 & $0.13 \%$ & 958 & 810,720 \\
Fordyce & 352,980 & 600,066 & $0.10 \%$ & 600 & 508,320 \\
Spens & 233,200 & 396,440 & $0.17 \%$ & 674 & 570,240 \\
Shear & 235,625 & 400,563 & $0.95 \%$ & 3,805 & $3,222,720$ \\
Parrish & 282,895 & 480,922 & $0.70 \%$ & 3,366 & $2,851,200$ \\
4-North & 366,633 & 623,276 & $0.15 \%$ & 935 & 792,000 \\
Honey Run & 360,288 & 612,490 & $0.25 \%$ & 1,531 & $1,297,440$
\end{tabular}

FED/GOB Meth Liberation 
EXHIBIT 7. Primary Project Area

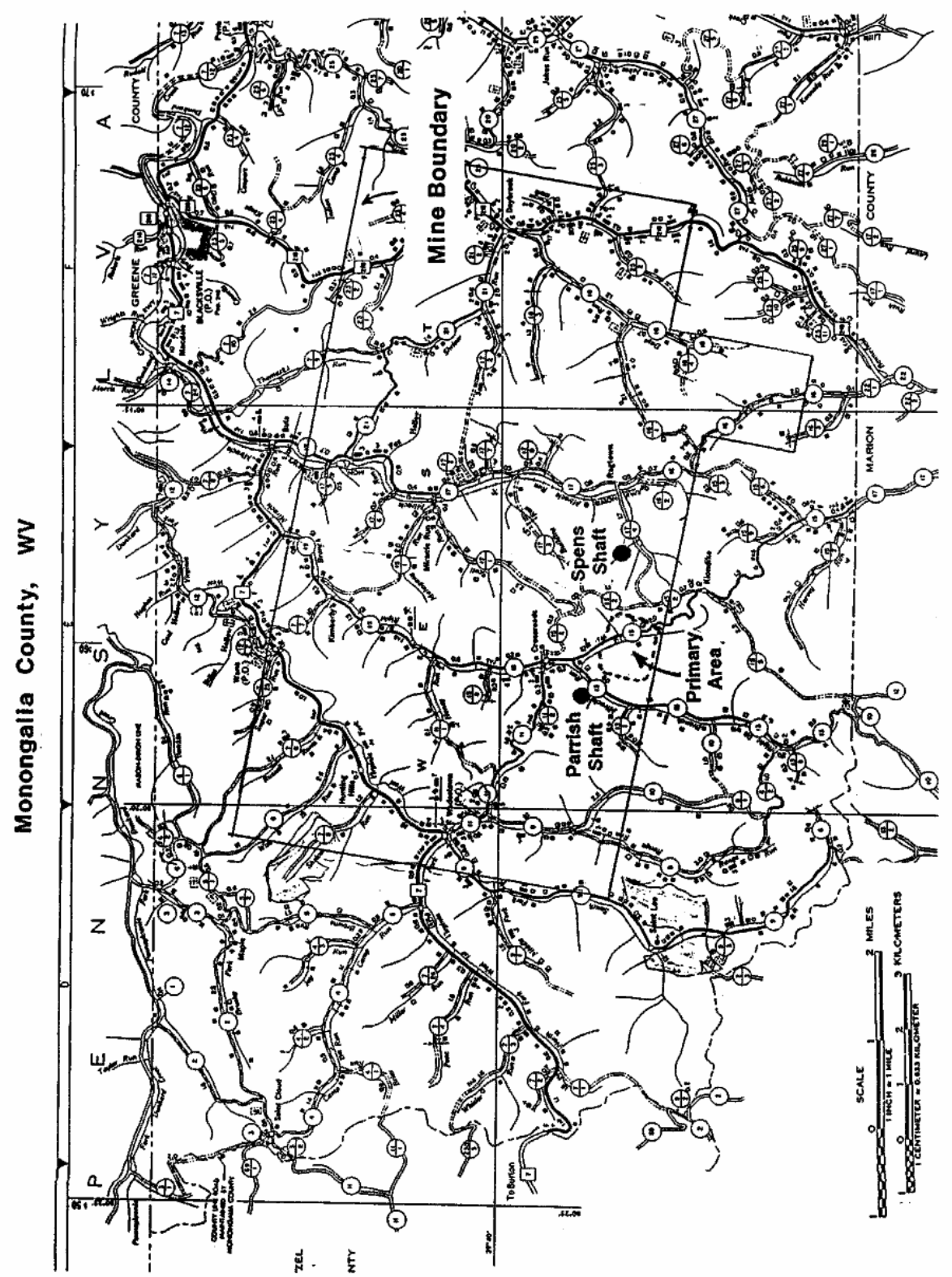


EXHIBIT 8. Gob Vent Hole Locations

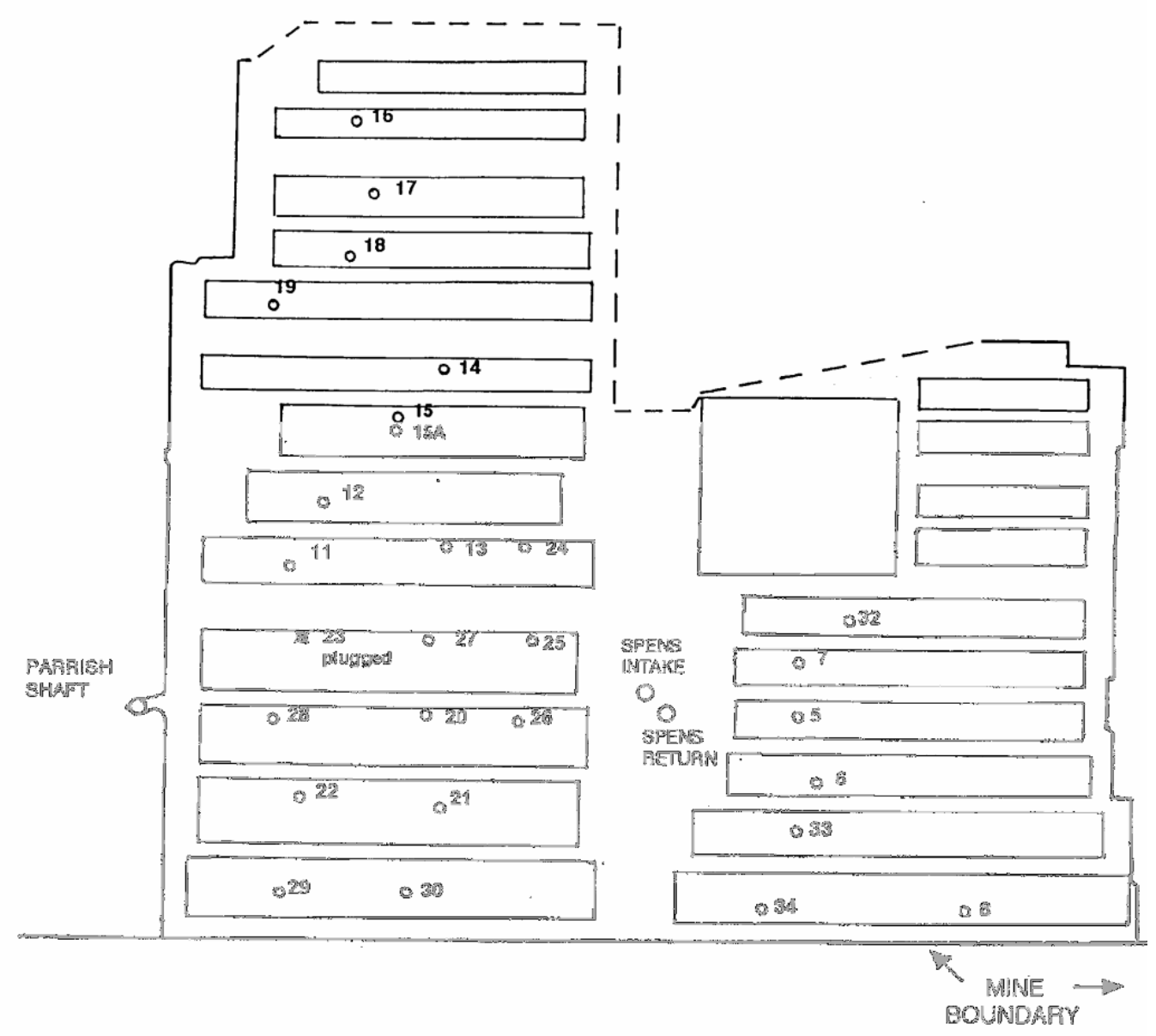


EXHIBIT 9. Gob Gas Vent Data Federal No. 2 Mine

1995

Gob Gas Gas $\quad \mathrm{CH} 4 \quad \mathrm{CH} 4$

Gas $\mathrm{CH} 4$ O2 CO2 Temp, Temp, Flow, Flow, Flow, Flow,

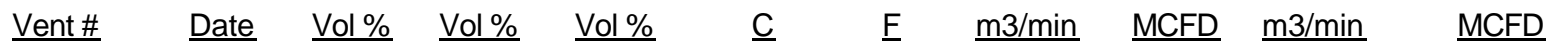

\begin{tabular}{|c|c|c|c|c|c|c|c|c|c|c|}
\hline 5 & 4/14/95 & & & & & & & & & \\
\hline 5 & 6/20/95 & & & & & & & & & \\
\hline 5 & 7/2/95 & & & & & & & & & \\
\hline 6 & 4/14/95 & & & & & & & & & \\
\hline 6 & 6/20/95 & & & & & & & & & \\
\hline 6 & 7/2/95 & 86 & & & 29 & 85 & 0 & 5 & 0 & 4 \\
\hline 7 & 7/2/95 & & & & & & 5 & 265 & & \\
\hline 8 & 4/14/95 & 89 & & & & & & & & \\
\hline 11 & 4/14/95 & 79 & & & & & & & & \\
\hline 11 & 6/18/95 & 76 & 1 & 1.5 & & & 1 & 37 & 1 & 28 \\
\hline 11 & 6/19/95 & 80 & 2.4 & 0.8 & 26 & 78 & 1 & 38 & 1 & 30 \\
\hline 11 & 7/1/95 & 74 & & & 22 & 72 & 0 & 20 & 0 & 15 \\
\hline 11 & 7/2/95 & 84 & & & 18 & 65 & 1 & 26 & 0 & 22 \\
\hline 12 & 6/19/95 & 57 & 6.3 & 0.8 & 26 & 78 & 1 & 33 & 0 & 19 \\
\hline 12 & 7/1/95 & 66 & & & 24 & 76 & 0 & 18 & 0 & 12 \\
\hline 13 & 6/19/95 & & & & & & & & & \\
\hline 13 & 7/1/95 & & & & & & 4 & 201 & & \\
\hline 15 & 7/1/95 & & & & & & 1 & 48 & & \\
\hline 20 & 7/1/95 & & & & & & & & & \\
\hline 21 & 6/20/95 & 90 & 1.6 & 2 & 16 & 61 & 1 & 41 & 1 & 37 \\
\hline 21 & 7/1/95 & 88 & & & 18 & 65 & 1 & 44 & 1 & 39 \\
\hline 22 & 4/14/95 & & & & & & & & & \\
\hline 22 & 6/20/95 & & & & & & & & & \\
\hline 22 & 7/1/95 & & & & & & 1 & 70 & & \\
\hline 24 & 6/18/95 & 44 & 9 & 4 & & & 1 & 41 & 0 & 18 \\
\hline 24 & 6/19/95 & 61 & 8 & 0 & 25 & 77 & 1 & 50 & 1 & 31 \\
\hline 24 & 7/1/95 & 61 & & & 24 & 75 & 1 & 41 & 0 & 25 \\
\hline 25 & 6/18/95 & & & & & & & & & \\
\hline 25 & 6/19/95 & & & & & & & & & \\
\hline 25 & 6/20/95 & & & & & & 1 & 38 & & \\
\hline 25 & 7/1/95 & & & & & & 1 & 51 & & \\
\hline 26 & 7/1/95 & 92 & & & 31 & 87 & 0 & 22 & 0 & 20 \\
\hline 27 & 6/19/95 & & & & & & & & & \\
\hline 27 & 7/1/95 & & & & & & & & & \\
\hline 28 & 7/1/95 & & & & & & 3 & 141 & & \\
\hline 29 & 6/20/95 & 93 & 1.9 & 0.5 & 22 & 72 & 1 & 41 & 1 & 38 \\
\hline 29 & 7/1/95 & 84 & & & 20 & 68 & 1 & 44 & 1 & 37 \\
\hline 32 & 7/2/95 & 79 & & & & & 0 & 9 & 0 & 7 \\
\hline
\end{tabular}


There are consistent differences between the 1995 survey of gob vent holes and the earlier $1990 / 91$ survey performed by CNGP. Some observations were made when comparing the results in Exhibit 5 (page 10) and Exhibit 9 (page 14). The methane concentration declined in virtually every vent from 1990/91 to 1995, but the total gas flow rate remained quite constant. In the case of Vent \#24, the methane concentration dropped, but the total gas flow rate actually increased to where methane flow rates were within $10 \%$ of each other.

There were more vents surveyed in $1990 / 91$ and the aggregate total methane flow was close to $10 \mathrm{~m}^{3} / \mathrm{min}$ (500 MCFD). There was a drop of $20-30 \%$ in the methane production from the vent holes which were surveyed in both time periods. That allowed one to make an estimation of total flow from all the vent holes in 1995, even though they were not all directly measured. This was accomplished by extrapolating the $1990 / 91$ results with a 20-30\% decrease in total methane flow. Based on this approach, there were 7 to $8 \mathrm{~m}^{3} / \mathrm{min}(350$ to 400 MCFD) of methane being vented from all of the gob vent holes in the Project Area. That was enough fuel to support at least $1000 \mathrm{kw}$ even without any attempts at flow enhancement.

\section{(1) Gob Vent Blower Tests (1996)}

Additional testing of gas production from a single gob well was performed during Phase II. Vent \#29 was selected due to its high gas quality and positive flows during all previous measurements. This Vent was selected as the primary fuel supply for this project.

Mine Gas flow from Vent 29 at the Federal No. 2 Mine was enhanced through the use of a portable $16 \mathrm{hp}$ blower unit. This blower was able to increase methane flow rates several fold from the natural convection rate of about $1 \mathrm{~m}^{3} / \mathrm{min}^{(50}$ MCFD). In one case the enhanced flow was $4 \mathrm{~m}^{3} / \mathrm{min}$ (200 MCFD). These higher flow rates were accompanied by moderate changes in the methane concentration of the vent gas. The gas was measured at 91\% CH4 before blower operation and this fluctuated between $84 \%$ and $89 \%$ during the blower trials.

Tests with the portable blower were carried out on two different occasions. On September 24-26, the blower was run for an extended period of time. Brief additional tests were performed on October 1, 1996. A summary of the September results are tabulated in Exhibit 10.

While fueled with the vent gas, the blower was able to impart a vacuum of 20 " $\mathrm{H}_{2} \mathrm{O}$ (water gauge). When gasoline was used as the fuel for the engine, the vacuum was able to be increased to $28 " \mathrm{H}_{2} \mathrm{O}$. The change in methane concentration was not directly proportional to the vacuum imparted on the Vent. The concentration appeared to recover even in the middle of an extended run.

Reservoir pressure recovery data were obtained at the end of the September tests. Graphs of these data are presented in Exhibits 11 and 12 . With the rapid recovery of reservoir pressure after blower shut down, these tests showed that this is a small-capacity fractured reservoir. The original reservoir pressure returns within an hour of blower shutdown. Most of the recovery occurs within the first 15 minutes.

The test on October 1 consisted of blower operation for about 1 hour and then data were recorded for reservoir recovery pressures. The methane concentration before the test was 90\%. It varied from 86-89\% while the blower was running. The reservoir pressure recovered to a positive value (from $29 " \mathrm{H}_{2} \mathrm{O}$ vacuum) in less than one minute. 
EXHIBIT 10. Gob Vent Blower Test Results (9/96)

9/24/96 19:00 hours - Vent under natural convection $\mathrm{CH}_{4}=91 \%$

Test

Time

(hrs): $\quad$ Observations:

0 Blower started on gasoline and switched to vent gas

$16 \mathrm{CH}_{4}=88 \%$; fuel switch to gasoline

18 Fuel switch to vent gas

$19.5 \quad \mathrm{CH}_{4}=84 \%$

$22.5 \quad \mathrm{CH}_{4}=89 \%$

$39 \mathrm{CH}_{4}=88 \%$

41

42.6

$\mathrm{CH}_{4}=84 \%$; fuel switch to gasoline

Blower shut off to measure reservoir pressure recovery

Recovery Test :

\begin{tabular}{c} 
Recovery \\
Time, min. \\
\hline 0 \\
1 \\
2 \\
8 \\
10 \\
12 \\
14 \\
16 \\
18 \\
20 \\
50
\end{tabular}

Vent

\begin{aligned} Pressure, $\quad \mathrm{H}_{2} \mathrm{O} \\$\hline-28 \\ -5 \\ -4.25 \\ -3.5 \\ -3.25 \\ -3.62 \\ -3.5 \\ -3.5 \\ +0.38 \\ +0.38 \\ +0.57\end{aligned}

43.4

44.2

Ran blower on gasoline

Blower shut off to measure reservoir pressure recovery

Recovery Test:

\begin{tabular}{cc} 
Recovery & Vent \\
Time, min. & Pressure, " $\mathrm{H}_{2} \mathrm{O}$ \\
\hline 0 & -28 \\
1.5 & -0.81 \\
2.5 & -0.31 \\
3.5 & -0.06 \\
5.5 & +0.19 \\
10.5 & +0.38 \\
15.5 & +0.5 \\
30.5 & +0.62
\end{tabular}


The gas production rates achieved with the blower during the september and october tests are presented in Exhibit 13. The highest flow rate in the September test was about 150 MCFD of $\mathrm{CH} 4$, whereas the October test was able to produce 200 MCFD of CH4. There is no current explanation for this difference of production rates since the vent pressure for both cases was comparable. The data show a definite proportional relationship between the vacuum imparted on the vent and the methane production rate. The data are somewhat scattered, but they were used for preliminary projections of flow from this Vent.

(Note: All of the recorded methane concentrations were measured with a MSA thermal conductivity methanometer. This portable instrument has been shown to be accurate within +/- 2.5\% of methane concentrations when compared to the results from a gas chromatograph.)

\section{(2) Gob Vent Blower Tests (1998)}

The enhanced flow tests performed during 1996 were limited due to the size of the blower which was employed. The 16 horsepower motor was not able to produce the gas flow levels which would be needed for the commercial facility. The early tests were valuable, since they allowed for the confirmation of higher flows than the natural convection. They also provided for an extrapolation of the flows. In order to make sure that some unforeseen problems would not arise with the fuel supply for the commercial facility, additional blower tests were performed during 1998. A much larger blower was used. A Tuthill positive displacement blower, driven by a 50 horsepower internal combustion engine, was used for these tests.

The details of the 1998 tests are provided in Appendix B. The pertinent results are as follows:

1) Vent 29 was tested for 5 days and found to be capable of producing over $4 \mathrm{~m}^{3} / \mathrm{min}$ (200 MCFD) of gas containing $90 \%$ methane.

2) Vent 30 was tested for 1 day and had a production capability in excess of $10 \mathrm{~m}^{3} / \mathrm{min}$ (500 MCFD) of gas containing $80 \%$ methane.

3) Vent 30 might have been capable of supplying the entire power generating fuel requirements.

4) Tests were run with wellhead vacuums which were less than the design conditions for the fuel supply system, hoping to make them conservative tests.

5) The reservoirs were well fractured, although the fractures around the wellbore are of limited size. After the blower was shut down, the reservoirs returned to ambient pressure in about one minute.

6) There appeared to be some sub-surface communication between the two Vents since pressures at one vent were affected by drawdowns at the second vent.

The conclusion from these tests was that these two Vents would be capable of providing the total fuel supply necessary for the power generating units to be installed at the Federal No. 2 Mine. Vent 30 might have even been capable of providing the total fuel supply. The other identified vents in the vicinity would provide insurance that there would be enough fuel for the plant in the long term. 
EXHIBIT 11. Vent 29 Pressure Recovery - A

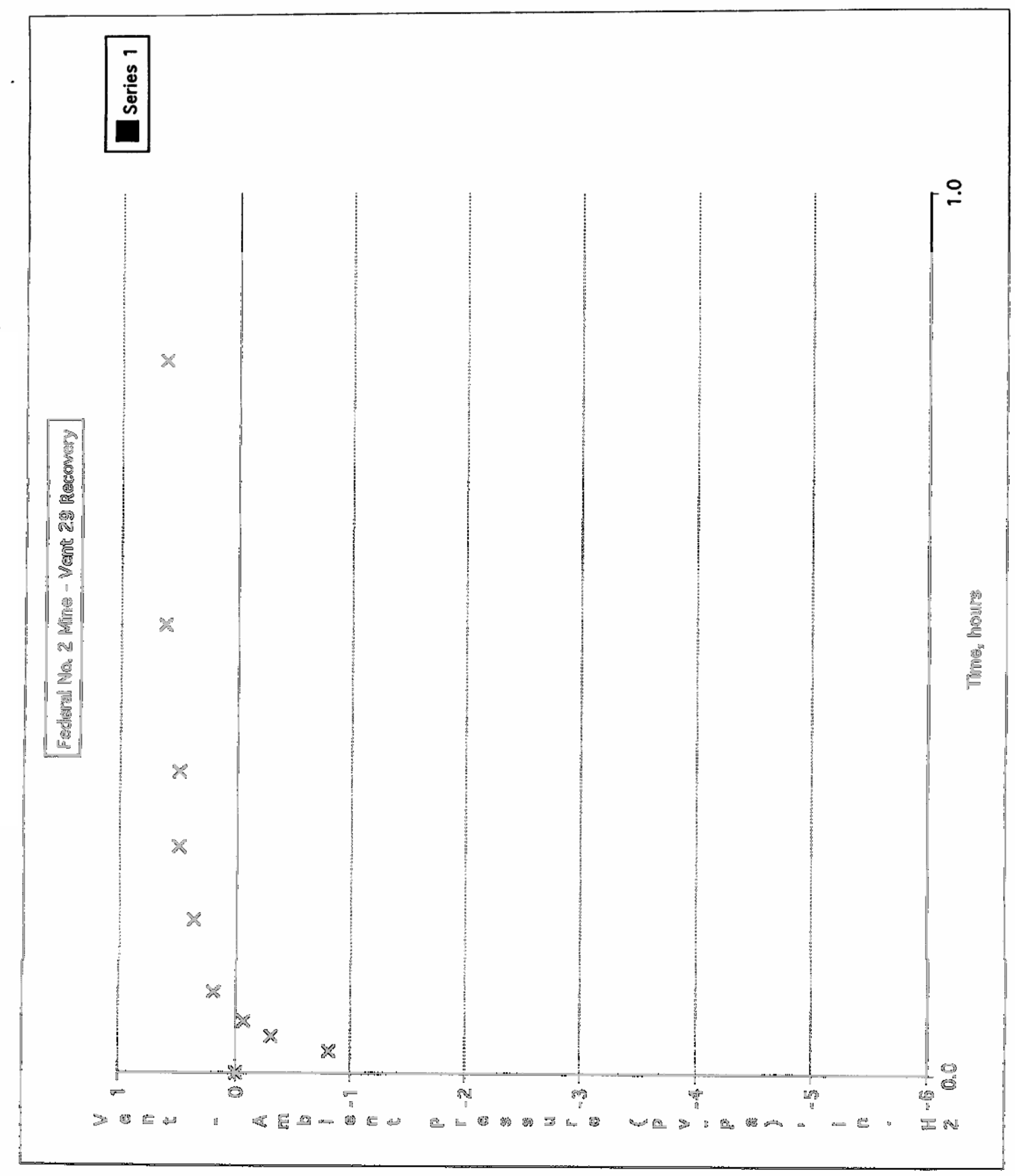


EXHIBIT 12. Vent 29 Pressure Recovery - B

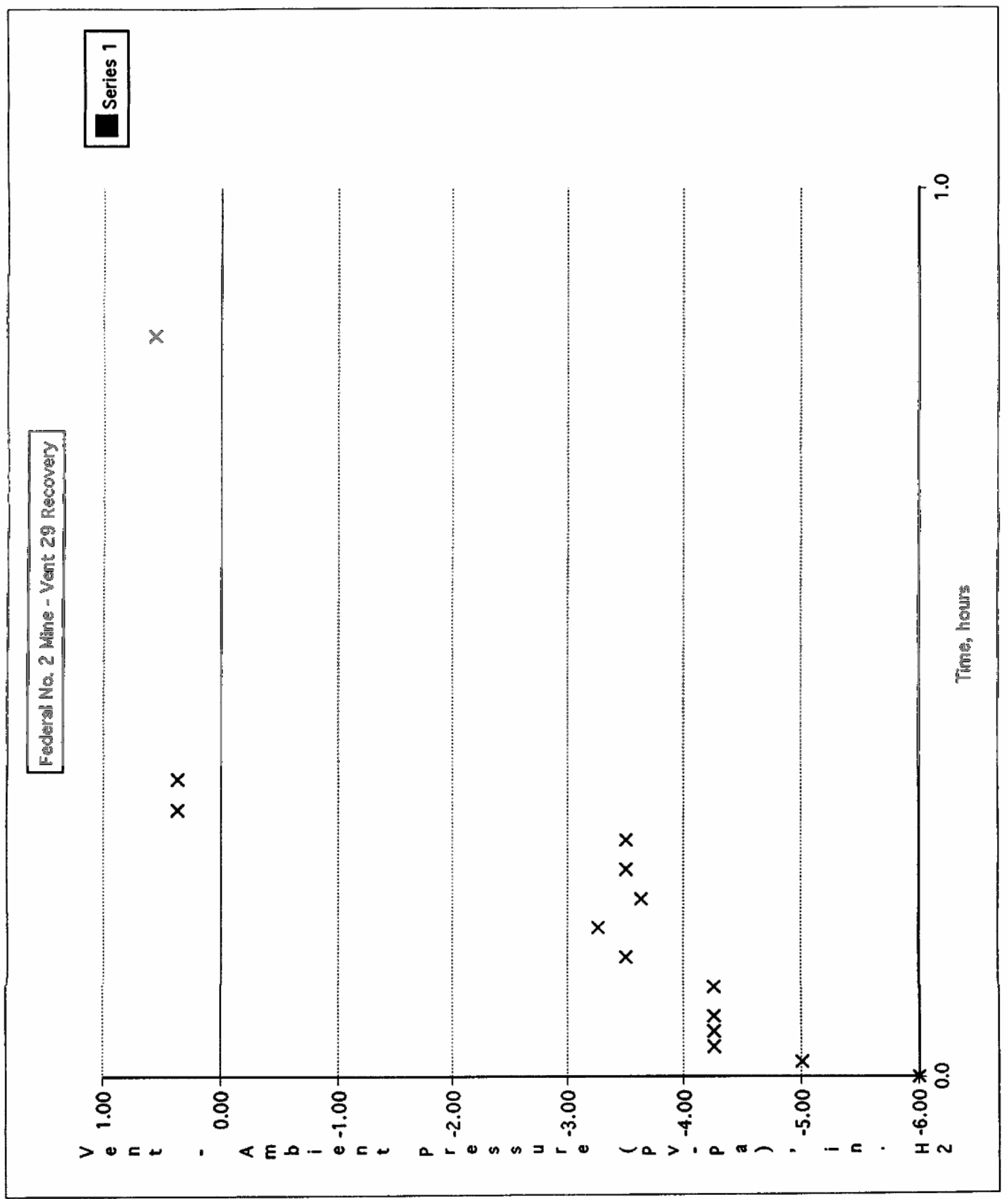


EXHIBIT 13. Vent \#29 Flow Potential

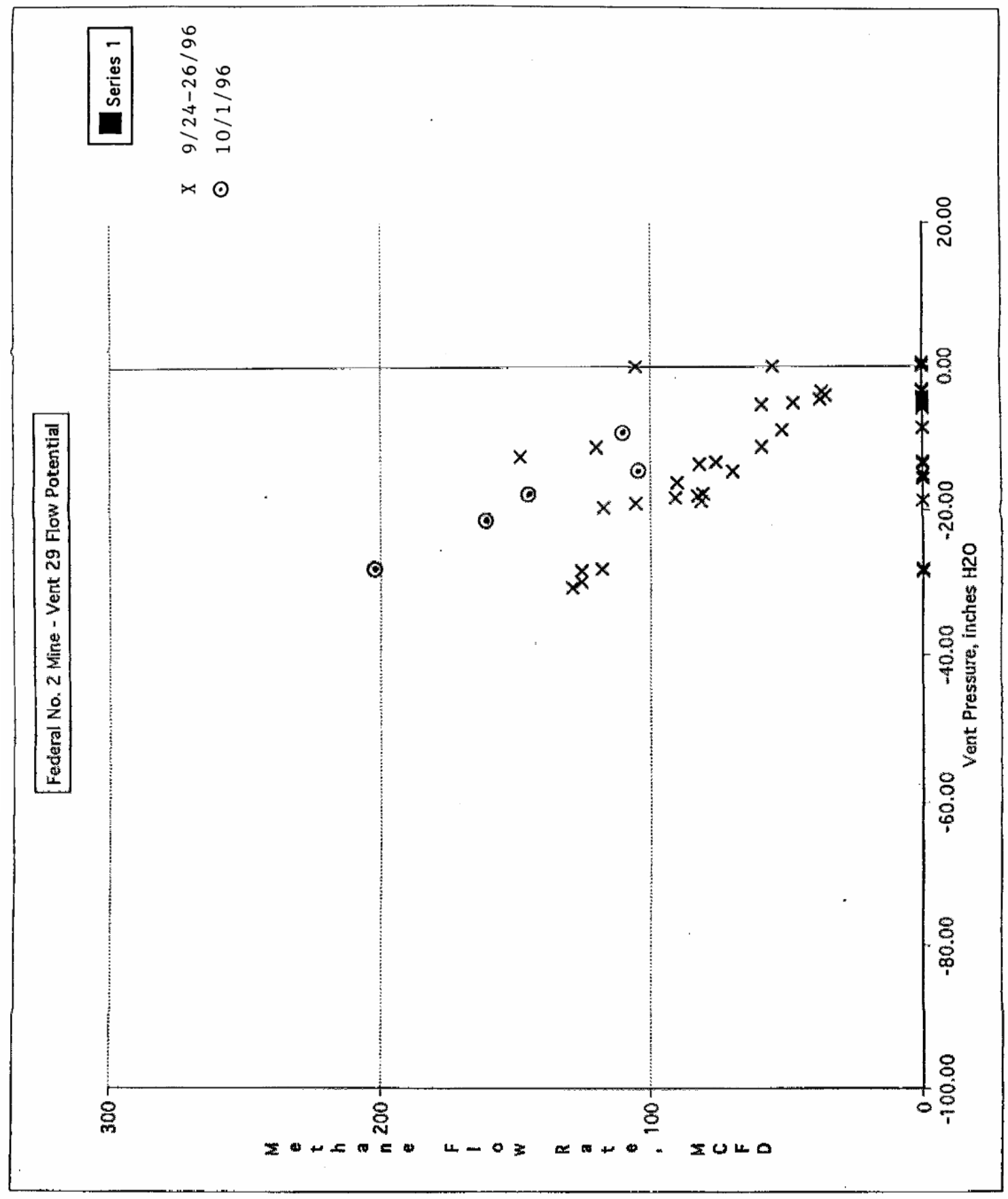




\section{B. Federal No. 2 Methane Resource/Reserve}

The coalbed methane resource in the Northern Appalachian Basin has been estimated to exceed $1.7 \times 10^{12} \mathrm{~m}^{3}$ (60 TCF) (Kelafant, et al). The Pittsburgh Seam alone is projected to contain $200 \times 10^{8} \mathrm{~m}^{3}$ ( $7 \mathrm{TCF}$ ) over a $15 \times 10^{9} \mathrm{~m}^{2}(6,000$ square mile) area. The Federal No. 2 Mine covers $85 \times 10^{6} \mathrm{~m}^{2}$ (33 square miles) in the heart of the Pittsburgh Seam region. Since the mining operation releases more than the gas in the seam being mined, it is important to understand the total gas resource in the Mine area. Estimates of methane resources which may be liberated during the mining operation are always very difficult to assess and a variety of factors will affect the actual emissions from a given mine.

There are numerous sources of gas which can emit methane into the mine workings. Coal seams above and below the mined Pittsburgh seam can be disturbed sufficiently to release methane into the mined-out area. Other geologic strata contain methane source rocks and methane reservoir rocks. Nearby oil and gas wells can emit methane into the Mine. It is virtually impossible to quantify these sources directly. The advantageous result in the present study was that more than one of the indirect methods provided results which were quite comparable. That provided some assurance that the individual methods provided reasonable estimates of methane gas resources at the Federal No. 2 Mine.

\section{Coal Seam Gas Resources}

One method for estimating in situ gas resources within a region is by determining the gas content of all coal seams in the stratigraphic column, defining the areal extent of the seams and specifying the seam thicknesses. The gas reserves of the entire Pittsburgh seam vary based on assumptions for bed thickness and gas content. The published estimates range from $17 \times 10^{9} \mathrm{~m}^{3}$ (600 BCF) by Deul (as referenced by Hunt and Steele), $45 \times 10^{9} \mathrm{~m}^{3}$ ( $1.5 \mathrm{TCF}$ ) by Diamond, et al, $110 \times 10^{9} \mathrm{~m}^{3}(4 \mathrm{TCF})$ by A. D. Little (as referenced by Hunt and Steele), and $200 \times 10^{9} \mathrm{~m}^{3}(7 \mathrm{TCF})$ by Kelafant, et al.

The aggregation of coal seams and gas contents was used to estimate the total gas in place within the coal seams at the Federal No. 2 Mine. It was assumed that all of the identified coals may release gas which could migrate into the mine workings, or into the gob vent holes. Such migration can occur over a considerable vertical and horizontal distance. To understand this, one need only consider the state of the subsurface before and after mining. Initially, the geological strata are nearly in a state of pressure equilibrium. In the geologic assessment in Appendix A, it was reported that the Pittsburgh Seam insitu pressure ranged from 1500 to $2200 \mathrm{kPa}(200$ to $300 \mathrm{psig})$. Once the Pittsburgh seam coal is removed, that means there is a significant pressure differential between the remaining unmined strata and the mine cavity. Such a pressure driving force can push gas for hundreds, if not thousands of meters. This is especially the case since the longwall mining procedure imparts significant fractures into the geologic formations near the mine workings.

Exhibit 14 presents the results of the coal seam gas content analysis for each known coal in the stratigraphic column at the Mine. The gas contents are from a compilation of data published by the US Bureau of Mines (Diamond, et al, 1986). The areal extent of the coals was assumed to be the entire $85 \times 10^{6} \mathrm{~m}^{2}$ $\left(20,800\right.$ acres) within the Mine boundary, with $1.3 \mathrm{~kg} / \mathrm{m}^{3}$ (1800 tons of coal per acre foot) of coal seam. Coal thicknesses were estimated from drill hole data within the Mine area. 
EXHIBIT 14. Coal and Gas Resources at the Federal No. 2 Mine

\begin{tabular}{|c|c|c|c|c|c|c|c|c|}
\hline \multirow[b]{2}{*}{ Coalbed } & \multicolumn{2}{|c|}{ Thickness } & \multicolumn{2}{|c|}{ Gas Content } & \multicolumn{2}{|c|}{ Coal Resources } & \multicolumn{2}{|c|}{ Gas Resources } \\
\hline & $\underline{\mathrm{cm}}$ & (in.) & $\underline{\mathrm{cc} / \mathrm{g}}$ & (CF/ton) & $\underline{\text { MM m.t. }}$ & (MM tons) & $\underline{10^{9} \mathrm{~m} 3}$ & $(\mathrm{BCF})$ \\
\hline Washington & 107 & 42 & 2 & 60 & 119 & 131 & 223 & 8 \\
\hline Waynesburg & 122 & 48 & 3 & 89 & 136 & 150 & 379 & 13 \\
\hline Uniontown & 61 & 24 & 3 & 100 & 65 & 72 & 204 & 7 \\
\hline Sewickley & 122 & 48 & 4 & 124 & 136 & 150 & 528 & 19 \\
\hline Fishpot & 15 & 6 & 2 & 72 & 17 & 19 & 39 & 1 \\
\hline Redstone & 28 & 11 & 4 & 128 & 31 & 34 & 123 & 4 \\
\hline $\begin{array}{l}\text { Pittsburg } \\
\text { Rider }\end{array}$ & 38 & 15 & 4 & 130 & 43 & 47 & 173 & 6 \\
\hline Pittsburgh & 229 & 90 & 7 & 225 & 238 & 262 & 1,672 & 59 \\
\hline Total for Bed & on & she & to & & 786 & 865 & 3,341 & 118 \\
\hline
\end{tabular}

FED/GOB Coal \& Gas Resources 
While most of the overlying coal seams are fairly shallow and contain small amounts of gas, the cumulative effect is significant. The gas content of the shallower coals nearly equals the amount of gas held by the Pittsburgh Coalbed. The Sewickley seam alone holds nearly $60 \times 10^{6} \mathrm{~m}^{3}(20 \mathrm{BCF})$.

An estimated total of over $3000 \times 10^{6} \mathrm{~m}^{3}(110 \mathrm{BCF})$ of methane is contained within the eight major seams. Several smaller, unnamed seams were also cut through during the drilling of the Multipurpose Borehole (MPB) (Fields, et al) at this Mine. The possible contribution of these seams was not quantified.

This estimate also does not include the possible contribution from underlying coal seams. There are insufficient data regarding the geographic extent of these seams within the Mine boundary. It is known that the deeper Freeport and Kittanning seams are not as continuous as the Pittsburgh seam. Suffice it to say that these seams could contribute a considerable amount of additional gas resources. The total coal seam gas resource could well be $4 \times 10^{9}$ to $6 \times 10^{9} \mathrm{~m}^{3}$ (140 to $200 \mathrm{BCF})$.

There are also non-coal strata, such as shales, which may have been sources of gas over geologic time. The sandstones in the area could provide possible reservoir sites for either the coal sourced gas, or other conventional natural gases. All of these elements could be disturbed sufficiently during the mining operation to release methane gas into the mine workings, either during the operation or much later. Some of these sources could supply gas into sealed mine areas for years - and even decades.

NW Fuel has developed gas resource estimates at other coal mines using the aforementioned seam gas content method. In every case, the actual methane emissions during mining operations from a specific area within a mine, have exceeded the values calculated for the gas in place. This work has included assessments of gas in-place within longwall panel areas. After calculating the gas in the individual longwall panel, the production from gob gas vent holes was monitored. The actual emissions from the vent holes generally exceeded the vent holes. It did not even consider the gas released from the gob area into the mine air ventilation system. The gob vent flows were only monitored for a fixed period of time. If the vent holes were left open for years, they would have produced even more methane. These results have been consistent in locations as far apart as Pennsylvania and Alabama. The conclusion from this consideration is that the gas which may eventually be produced from the Federal No. 2 Mine as a result of mining will likely exceed $6 \times 10^{9} \mathrm{~m}^{3}(200 \mathrm{BCF})$.

Using this methodology for the Project Area, one can estimate the total amount of gas which would eventually be emitted from this limited Area. The Project Area constitutes about $17 \%$ of the total Mine area. That indicates that there were $600 \times 10^{6} \mathrm{~m}^{3}(20 \mathrm{BCF})$ of defined gas resources in the virgin coals within this Area. Applying NW Fuel's empirical experience to this value indicates at least $900 \times 10^{6} \mathrm{~m}^{3}(32 \mathrm{BCF})$ of initial total gas resources in the Project Area.

\section{Oil and Gas Well Contribution}

Abandoned gas and oil wells are known to have a profound effect on methane emissions in coal mines. With the historic activity in oil and gas exploration in this area, this could be of significant impact. Monongalia County has had a long history of fossil fuel production, including oil production from 1892, coal production from 1836, and natural gas drilling which started during World 
War I. Drilling for oil stopped in 1910 and there has been little success with newly drilled gas wells since 1940 (Ulery and Molinda).

The potential impact of oil and gas wells on ventilation methane loading has been studied quite extensively at the Federal No. 2 Mine. A complete methane survey was performed within the Mine workings. Velocity, pressure, temperature, cross-sectional area, and methane concentration measurements were taken at strategic locations throughout the Mine while mining was active and also during idle times. Methane emissions were found to be generally higher along faces adjacent to virgin coal and higher when a return intersects the face cleat at right angles (Zabetakis, et al).

Due to variations in air/methane mixing, the raw figures varied markedly. A method of moving averages was used to smooth the data. The methane flow was plotted against distance along the East Mains and 2 South Mains (see Exhibits 15, 16, and 17 - from Zabetakis, et al). Differentiating this curve yields a measure of the amount of gas evolved per distance. Very pronounced peaks could be observed which correlated with communication with a gas or oil well. The positions of these peaks indicated that the methane passes more readily along the face cleat. A major peak occurred at a mine entry location where oil well 80 was nearly 150 meters (500 feet) away, along the strike of the face cleat. This same oil well made no measurable impression at $1 / 2$ this distance along the strike of the butt cleat.

Subtracting these peaks, an estimation of the "expected" methane emissions could be made. Without the contributions of the oil and gas wells, the rib emission rate was $0.045 \mathrm{~m}^{3} / \mathrm{hr}$ per meter of rib $(0.008 \mathrm{cfm} / \mathrm{foot})$ for paths $1-5$ and $0.28 \mathrm{~m}^{3} / \mathrm{hr}$ per meter of rib $(0.05 \mathrm{cfm} / \mathrm{foot})$ for $\mathrm{A}-\mathrm{F}$. The oil and gas wells were adding 58\% to the overall methane loading.

The mined area in the Federal No. 2 Mine has over 2,200 meters (7, 300 feet) of rib. Using the average rib emission data from above, oil and gas well effects would account for over $7,800 \mathrm{~m}^{3} / \mathrm{min}$ (400 MCFD) of methane in the ventilation air.

\section{Other Potential Gas Sources}

Abnormally high methane emissions were encountered in eastern sections of the Federal No. 2 Mine during the sinking of the Shrivers Run Shaft and the driving of East bleeders and the tunnel towards the Shrivers Run shaft. An investigation into the source of these emissions indicated a potential reserve of gas trapped in a sandstone channel with a north-south trend which communicates with the mine through a clay vein and associated fracture system. other wells have also indicated this reserve and several wells have been drilled into Pennsylvanian sands for the express purpose of gas production, achieving moderate amounts of success (Ulery and Molinda). This is rather unusual as sand channels are typically associated with low methane instabilities (Diamond, et al, 1988).

Clay veins have been associated with both high and low emission rates. They are thought to be forced into the bed after coalification. These veins can be vertically situated and pass through many layers of strata. They have been shown to isolate large volumes of gas under pressure (Diamond, et al, 1988). 
EXHIBIT 15. Federal No. 2 Mine - Northeast Quadrant

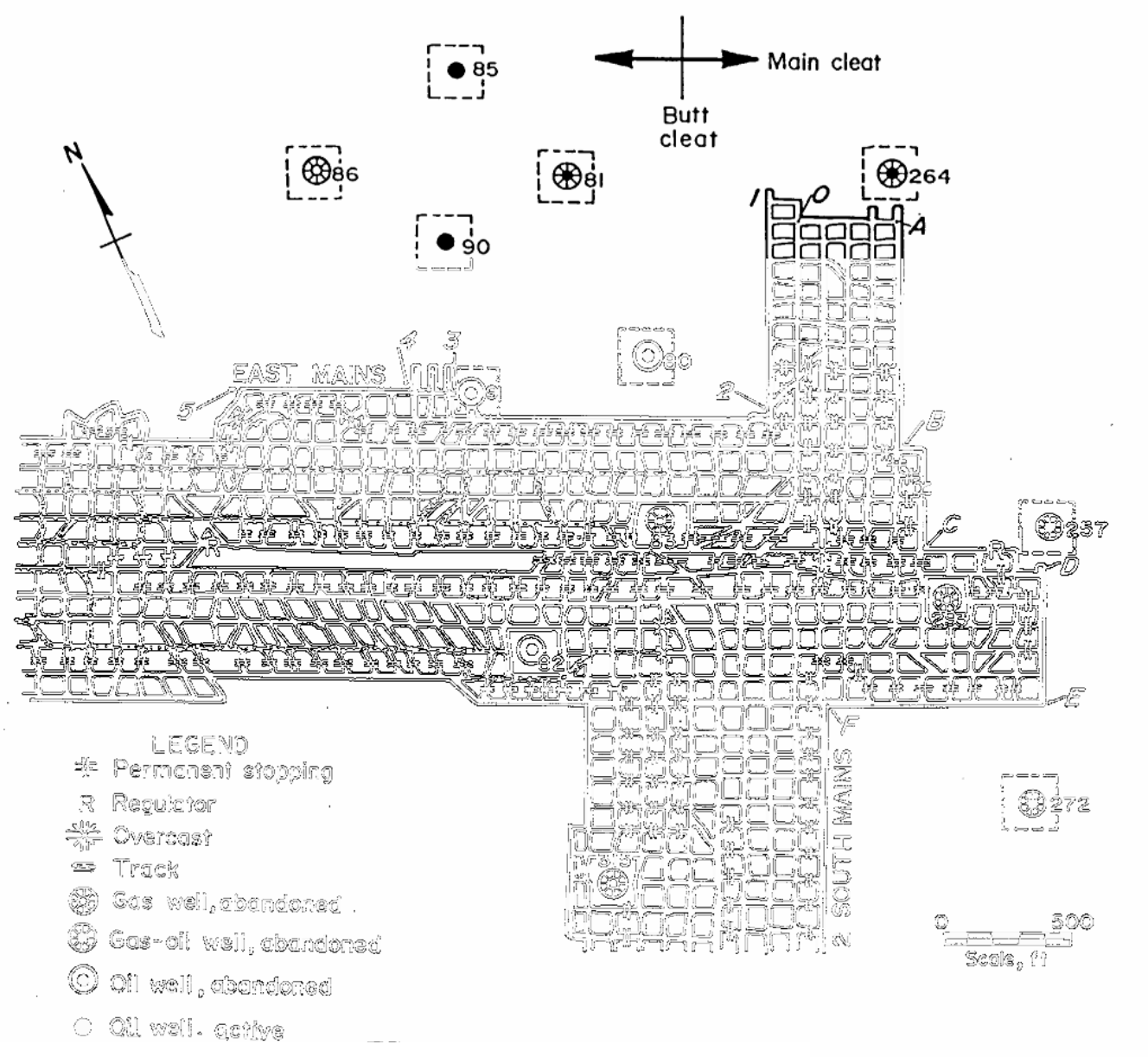


EXHIBIT 16. Methane Flow Rate: Left Air Course, NE Quadrant
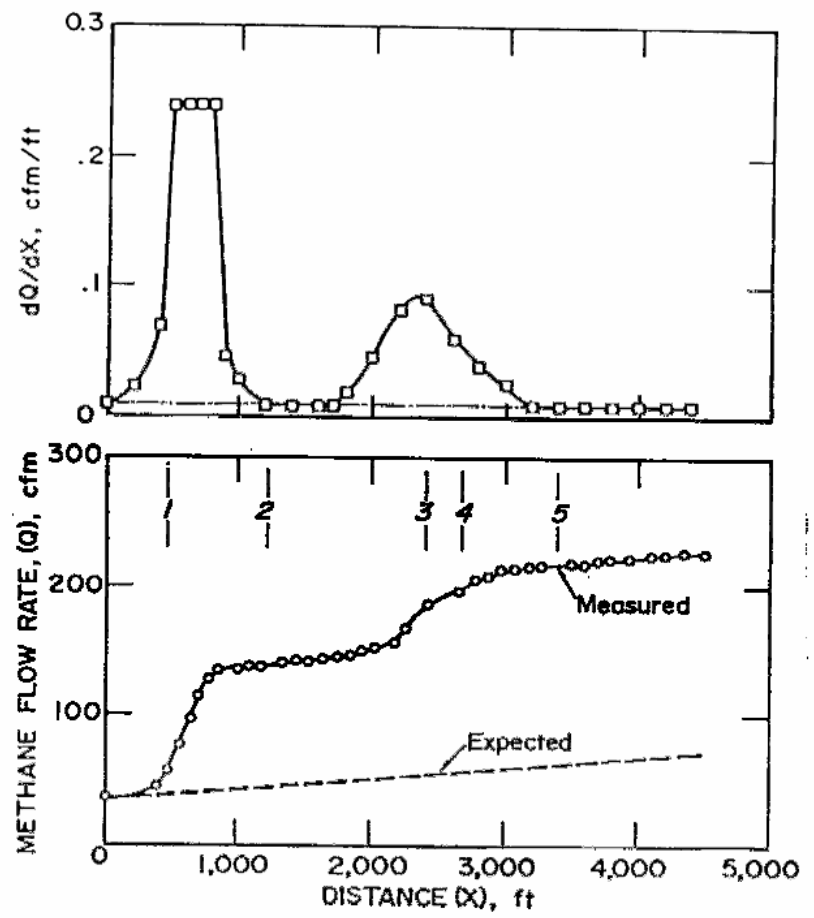
EXHIBIT 17. Methane Flow Rate: Right Air Course, NE Quadrant
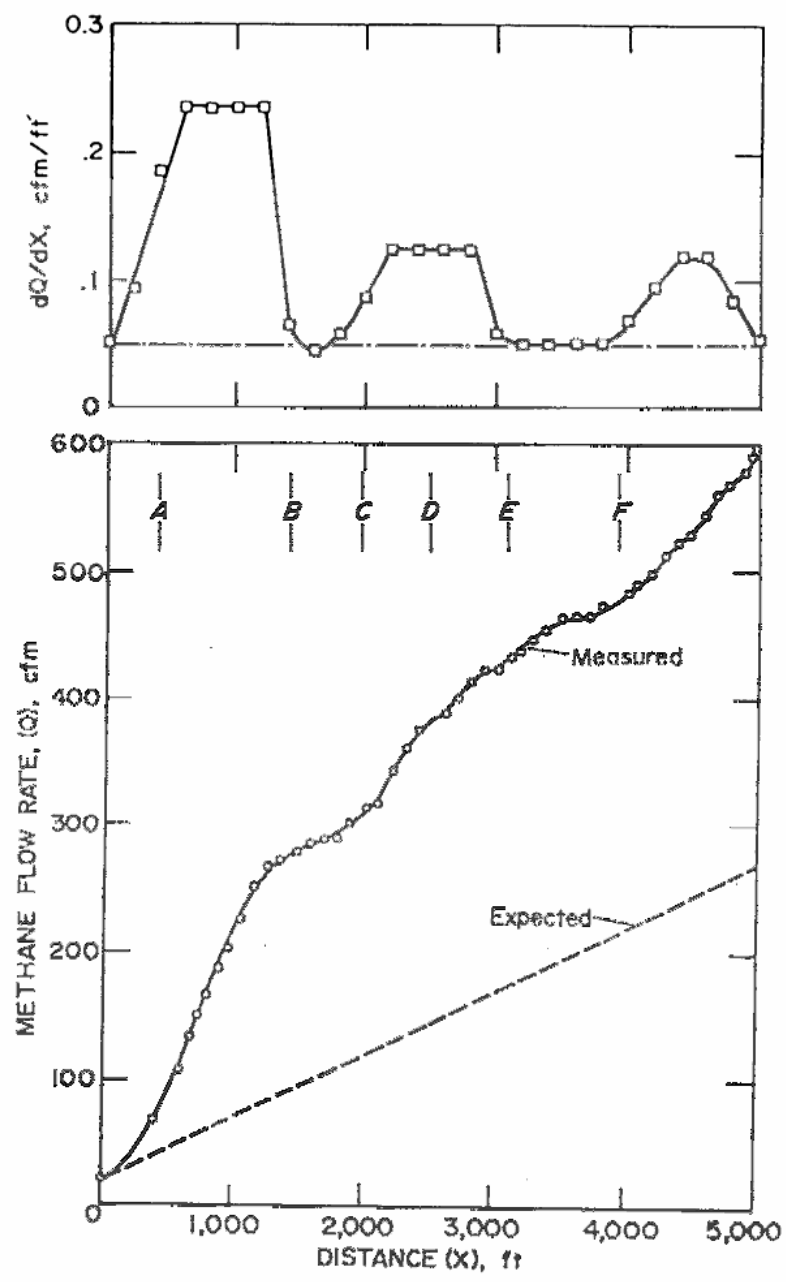


\section{Methane Resource Estimate from Mine Emissions}

Many authors have attempted to correlate the ventilation air methane emissions with the gas content of the coal being mined. This type of estimate is fraught with errors, based on the impact of all the other possible gas sources described above. These other gas sources can be correlated to the coal being mined. In a given mining region this method may provide some insights, but it should not be extrapolated globally.

Kissell has correlated the methane emitted from ventilation shafts with the amount of in situ gas in the coal being mined. He found that the methane vented during the mining process was 6 to 9 times the amount of gas which is contained within the seam being mined (TRW). This empirical value accounts for all methane sources, including gas from the coal which is left behind unmined. As was noted in the Mine Gas Availability section of this report, mines active in the Pittsburgh seam emit 30 to 60 CC of methane per gram (1000 to 2000 cubic feet of methane per ton) of coal mined. Using Kissell's factor in reverse on a moderate value of $45 \mathrm{cc} / \mathrm{g}$ (1500 ft3/ton), that would project that the Pittsburgh Seam contains 5 to $8 \mathrm{cc} / \mathrm{g}$ (170 to 250 cubic feet of methane per ton) of methane. That is a very accurate range for the Pittsburgh seam gas content, as verified by a variety of published sources.

Modifying this concept, one can develop another method for estimating the inplace gas resources which may be emitted during mining operations. If one measures and calculates the amount of methane emitted per ton of coal mined, this value can then be applied to the coal that is left behind as an indication of cumulative emissions which may occur in the future. It would somewhat overstate the future production, since this overall factor includes the contribution from a partial degassing of the unmined coal as the mined coal is being removed. That component is less than 30\% of the total, and more than likely less than $20 \%$ of the total.

The result of the emission resource estimate is presented in Exhibit 18 . The amount of coal and in situ gas within the Pittsburgh Coalbed within the Federal No. 2 Mine area was estimated from the seam thickness and total Mine area (see Exhibit 14). The original recoverable coal reserves were estimated to be 130 million metric tons (140 million short tons) based on the in-place resources of 240 million metric tons (260 million tons) and assuming a 55\% recovery factor. The remaining recoverable coal reserves were then projected to be approximately 70 million metric tons (80 million tons), by subtracting the estimated cumulative coal production since its opening in 1967 . This leaves a two decade coal reserve for the Mine at present production rates.

The original Pittsburgh Seam contained about $1.7 \times 10^{9} \mathrm{~m}^{3}$ ( 60 BCF) of methane gas. The recoverable Pittsburgh seam reserves contained about $930 \times 10^{6} \mathrm{~m}^{3}$ ( $33 \mathrm{BCF}$. Accounting for all possible sources of methane, there would have been about $6.8 \times 10^{9} \mathrm{~m}^{3}(240 \mathrm{BCF})$ of methane which would be emitted during the mining of 130 MM metric tons (140 MM tons) of the Pittsburgh Seam. This is based on the recoverable Pittsburgh seam 130 MM metric tons (140 MM )tons multiplied by an emission factor of $46 \mathrm{cc} / \mathrm{g}$ (1700 ft3/ton). This emission factor consists of two elements. The first part is the methane emissions from the ventilation system, $41 \mathrm{cc} / \mathrm{g}$ (1530 ft3/ton) of mined coal (see Exhibit 4). The second part accounts for the gob vent holes. Söot (1990) found that coal mines operating in the Pittsburgh Seam in southwestern Pennsylvania produced an average of 5 cc/g (164 ft3 per ton) of methane from gob vent holes from coal mined from the Pittsburgh Seam. Adding the two components provides an emission factor of 50 cc/g $(1,700$ ft3 of methane per ton) of Pittsburgh seam coal that is mined. 
EXHIBIT 18. Predicted Mine Methane Emissions

$\underline{\text { SI Units }}$

Original Resources

Pittsburgh Coal in Federal No. 2 Lease

In Situ Pittsburgh Coalbed Methane

Recoverable Reserves:

Recoverable Pittsburgh Coal

Methane in Recoverable Pittsburgh Coal

Total Mining Methane Emissions

Coal Production to Date:

Remaining Recoverable Reserves:

Remaining Recoverable Pittsburgh Coal

Methane in Remaining Pittsburgh Reserves

Total Future Mining Methane Emissions
$240 \mathrm{MM}$ metric tons

$1.7 \times 10^{9} \mathrm{~m}^{3}$

130 Million metric tons

$930 \times 10^{6} \mathrm{~m}^{3}$

$6.8 \times 10^{9} \mathrm{~m}^{3}$

$55 \mathrm{MM}$ metric tons

$75 \mathrm{MM}$ metric tons

$510 \times 10^{6} \mathrm{~m}^{3}$

$4 \times 10^{9} \mathrm{~m}^{3}$
American Units

$260 \mathrm{MM}$ Tons

$60 \mathrm{BCF}$

140 MM Tons

$33 \mathrm{BCF}$

$240 \mathrm{BCF}$

60 MM Tons

80 MM Tons

$18 \mathrm{BCF}$

$140 \mathrm{BCF}$

FED/Predicted Mine Meth Emissions 
Based on this same methodology, future emissions from the Mine during mining operations would be about $3 \times 10^{9} \mathrm{~m}^{3}(110 \mathrm{BCF})$ of methane.

The methane emission will not stop after mining is completed. All of the "other" methane sources will still be emitting methane into the old mine workings. That includes the remaining Pittsburgh seam coal, other overlying and underlying coal seams, the other gas bearing strata, and the nearby oil and gas wells. The only manner for predicting those types of reserves would be to associate the $50 \mathrm{cc} / \mathrm{g}(1,700 \mathrm{ft} 3 / \mathrm{ton})$ emission factor with the remaining Pittsburgh coal which was left behind after mining.

Based on the data in Exhibit 18, there will be about 110 MM metric tons (120 million tons) of Pittsburgh coal left in the abandoned mine. There would be up to 200 BCF of methane associated with that coal and "other" sources. Since a large part of the gas in the remaining coal was emitted during the active mining, and it does not have a counterpart "remaining" coal, this total should be reduced by some factor. It is hypothesized that the reduction factor would be $30 \%$ to $50 \%$. This reduction factor accounts for the prior degassing of the remaining Pittsburgh seam and also the partial degassing of the "other" methane sources. That means that the sealed mine could still produce over $3 \times 10^{9} \mathrm{~m}^{3}(100$ $\mathrm{BCF}$ ) of methane after the active mining is completed.

\section{Resource Conclusions}

Taking 17\% of this amount for the area which is now under consideration for power generation, that indicates the Project Area would have about $570 \times 10^{6} \mathrm{~m}^{3}$ (20 BCF) of recoverable methane left for the proposed project. This resource would be large enough to support 8 MW of power generation for 20 years.

The previous values should be used as guides and not as precise estimates of the gas resources at the Federal Mine. They are reasonable, based on NW Fuel's past experience with gas production from sealed mines. As an example, one gob well which NW Fuel is using to supply fuel to a power generating unit in ohio is producing $10 \mathrm{~m}^{3} / \mathrm{min}$ ( $500 \mathrm{MCFD}$ ) of high quality methane over 50 years after its section of the mine had been sealed.

\section{Phase III Results}

Even with all of the conservatism in making the resource and producibility estimates, the actual results in Phase III were considerably different than anticipated. A pipeline was constructed from Vent 29 to the Parrish Shaft. After its completion, and the installation of the power generating units, the gas production soon fell far short of the fuel requirements for the $1,200 \mathrm{~kW}$ of installed capacity. It became evident that another gob well would have to be connected to the pipeline.

Gob Well \#27 was tested and was connected to the pipeline. It also declined rapidly in production.

There was still no doubt that enough methane was available, the problem became one of accessing that gas and bringing it to the generating units. The final solution would have to be waiting for parts of the mine to be sealed. Unfortunately, when the area to the east of the Parrish shaft was sealed in 1998, there was no relief. A new vent was drilled into that section of the sealed mine from the Parrish Shaft site. For some unexplained reason, the methane concentration in that area has never risen over $14 \%$. That is not of sufficient quality to run the engine/generators. There must be a major source 
of air that continues to flow into that area in order to keep the methane concentration at such low levels.

When the area to the west of the Parrish Shaft was sealed, an adequate CMM fuel source finally became available. This area was sealed in January 2004 . By July, the methane concentration had risen to $60 \%$ and higher. It was also producible at sufficient quantities to fuel the entire installation of power generators. It was fortuitous that the mine had left behind a vent that could be used to bring the CMM to the surface right at the Parrish Shaft. This vent was originally drilled as a grout hole. The pipe was used to deliver grout to the mine. The grout was used to build the seals for the 1991 sealing of the area to the east of the Parrish shaft.

The Grout Pipe at the Parrish Shaft has been capable of producing nearly $1,000,000$ cubic feet per day (1 MMCFD) of CMM. This CMM contains about 60\% methane. The actual concentration varies with numerous parameters, including barometric pressure. This source could provide enough fuel to generate nearly 2 MW of electric power.

\section{Technology Application}

\section{Comprehensive Plan}

The coal mine methane utilization design for the Federal No. 2 Mine was envisioned as an integrated system. It would not only incorporate a power generation option with a gas processing system, it would even use several sources of coal mine methane. There were synergies between the power generation and the gas processing. The gas processing requires power and the power system could use the waste stream from the processing to fuel the generators. By using several sources of CMM one could make optimal use of the waste methane by matching the appropriate quality of methane to the best corresponding utilization process. Gas which was acceptable to a natural gas pipeline could be delivered to that market. Unacceptable, lower quality gas would be utilized for power generation. This low quality gas could even include the extremely dilute methane in the ventilation air shaft exhaust. By integrating this total system, NW Fuel could make optimal use of the available coal mine methane.

The total system is depicted in Exhibit 19. This shows the gas supply being gathered from a number of sources. It was to be delivered to the plant at the Parrish shaft site. The best quality gas woudl be processed through the PSA NRU with the product being delivered to a pipeline. The lower quality gas would be sent to the power generating units. The low quality gob gas is supplemented with the "waste" gas from the PSA NRU for power genset fuel.

\section{Technology Availability}

NW Fuel started this project with a plan to utilize power generating technology which the Company had developed at other coal mine sites. The pipeline delivery of gas would rely on yet another technology developed by NW Fuel: Pressure Swing Adsorption (PSA). This latter technology allows for the removal of excess nitrogen from the waste methane. Adding available commercial processes for gas compression, $\mathrm{CO}_{2}$ removal and dehydration, the project could deliver pipeline quality gas and generate power from a part of the Mine where there was no pipeline quality gas, and all of the sub-quality methane was being vented into the atmosphere. 
EXHIBIT 19. Waste Methane Utilization Systems Schematic

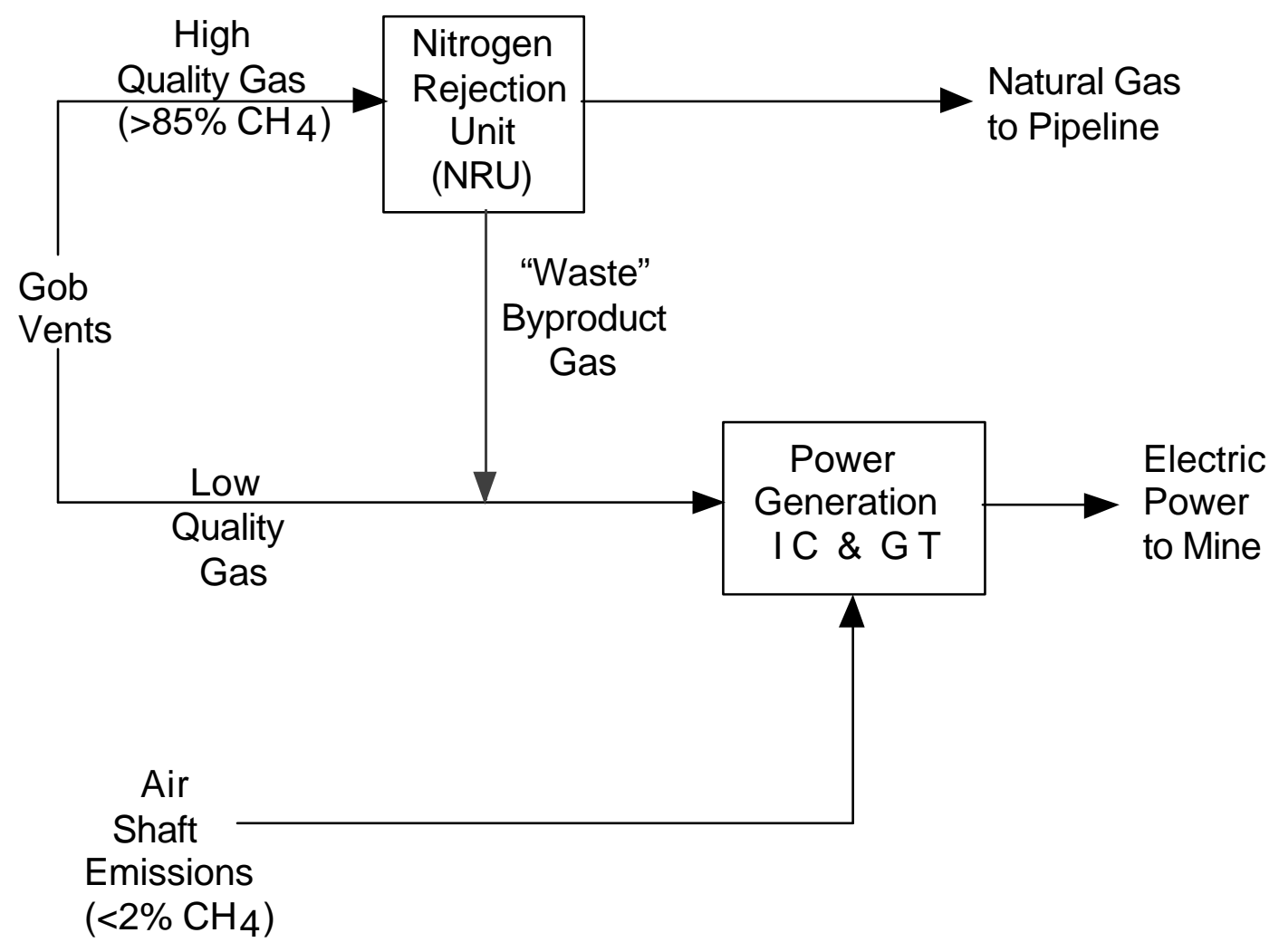


By developing such a comprehensive utilization package for coal mine methane, NW Fuel could provide a guide for other coal mines which need options for utilization of their methane resources. The total system could be used as a complete template, or individual components of the system could be segregated for use at other mines.

\section{Waste Methane Utilization Strategy}

None of the waste methane from the Project Area of the mine met natural gas pipeline specifications. It contained too much nitrogen, carbon dioxide and/or water. There were commercially available processes for removing the carbon dioxide and water, but no generally available processes for rejecting nitrogen from such a small source. Fortunately, NW Fuel had developed such processes. The PSA processes are able to remove some nitrogen from waste methane streams and be commercial on a small scale.

As indicated in the blower test data in Appendix B, the methane levels in the gas from Vents 29 and 30 were not of pipeline quality. The gas streams contained $2 \%$ to $10 \%$ nitrogen, along with nearly $2 \% \mathrm{CO}_{2}$. In order to meet pipeline specifications, the total inerts $\left(\mathrm{CO}_{2}+\mathrm{N}_{2}\right)$ need to stay below $4 \%$. The total blend of gas would not meet this maximum limit. In addition, some of the early blower tests indicated that the nitrogen concentration would rise once the gas is produced. That was definitely the case once they were put on continuous production. That would definitely require nitrogen rejection before the gas could be delivered to the pipeline.

Any gas which could be brought to pipeline quality standards, would be used in the power generation units. This would be supplemented with the waste gas from the Nitrogen Rejection Unit (NRU). In the process of removing the nitrogen the CPSA Unit has a "waste" stream. This waste stream provides gas which contains $50 \%$ to 70\% methane. The power generating sets are able to use that as a fuel so it is not really wasted. NW Fuel's power generating units have been run on gas as dilute as 25\% methane. That shows the broad applicability of these units.

\section{Power Generation with Internal Combustion Engines}

The power generating system was based on small generating units (in modules of $75 \mathrm{kw}$ each) which NW Fuel has developed in previous projects. The fundamental units include an internal combustion engine driving an electric generator. What this approach loses in economies of scale, it makes up in economies of mass production. The engines which are used are mass produced by General Motors as light truck engines. The capital cost per installed horsepower of prime mover is much lower than any other alternative.

\section{Mine Air Shaft Methane Utilization}

This project had originally considered use of the waste methane from the Parrish Shaft. This is an extremely dilute source. Mining regulations require that the methane concentration remain below 1\% methane. Since this will not combust on its own, it could have been used as the combustion air supply for the IC engines and the gas turbine. Unfortunately, the mine decided to use the Parrish Shaft as an inlet air shaft before the project started. That eliminated this as a supplemental source of methane fuel. Eventually the Parrish Shaft was closed permanently. It turned out that this was a benefit for the project since it allowed fuel gas to accumulate in the western part of the sealed area. This was subsequently used as fuel, being delivered from the Grout Pipe. 


\section{Development Strategy}

Even in the early stages of the Phase III development, there were some questions regarding the quality of fuel from individual gob vent holes and timing of mining developments in the Proposed Project Area. Fortunately, it was not necessary to immediately install the entire proposed system at once. It could be staged as some of the unknown variables were defined.

The gas quality issue related to the long term methane concentration from the various vents. Although the Phase II tests were run for up to 5 days on a vent, there was still the possibility that the methane concentration could change over a longer period of time. That was found to be the case as they were put in production.

The second issue related to the operations at the proposed site: the Parrish Air shaft. The fan at this shaft had been taken out of service temporarily. This was a planned operation. The air from this shaft is currently not needed for the mining operation. The entries into the shaft from the east were sealed in 1998. As the mining approached the shaft from the virgin coal to the west, the shaft was put back into service.

As a result of these issues, a strategy had been developed for the phased development of the methane gas resources at this site.

The phased development was to have the following steps:

1) Install a gathering line to Vents \#29 and \#30 plus a vacuum blower at the Parrish shaft.

2) Begin fabrication and installation of 5 internal combustion (IC) engine generators (375 kw aggregate capacity).

3) Monitor the Vent \#29 and \#30 gas quality and productivity as the gensets are being fabricated and installed. Proceed with step 6 if the fuel gas availability is confirmed.

4) Evaluate the productivity potential of other vent holes.

5) Fabricate and install a NRU for delivering pipeline quality gas. Use the "waste" stream from the NRU for genset fuel, supplemented by direct gob gas from vents.

6) Decide the configuration for additional generating capacity: IC engines or gas turbine.

7) Fabricate and install the additional generator(s) .

8) Install ducting to deliver Parrish Shaft exhaust air to the gensets as combustion air.

9) Continue the evaluation of additional vent holes and installation of added process or generating equipment.

Steps 1 and 5 were actually accomplished in parallel for a more rapid development program. The following sections of this report identify the stages of the proposed development in more detail. 


\section{Fuel Supply}

The availability of gas from the gob vent holes had been defined with the work accomplished during Phases I and II. The analysis showed that the free-flow gas production from the vent holes in the southern end of the Mine was limited. Rather than try and hook up enough vent holes to provide the fuel for an entire 1 MW of generating capacity from only natural convection, blower tests were performed that verified the deliverability of the gas with vacuum blowers imparting forced convection on the vents.

The Project took place at the Parrish Shaft. This shaft was chosen since it provided the best potential combustion air. The methane concentration at that Shaft was $>0.5 \%$. The alternative, spens Shaft (also within the Project Area), produced only $0.2 \%$ methane in the air. Each of these locations had the necessary electrical sub-station for delivery of the generated power.

The two vent holes targeted for initial development were \#29 and \#30. As was shown in Exhibit 8, these are some of the closest Vents to the Parrish Shaft. They were capable of producing more methane than the closer ones. Even with natural convection, Vent \#29 produced enough fuel to fire $150 \mathrm{kw}$ of generating capacity .

A gathering line was designed for bringing gas from Vents 29 and 30 to the Parrish Shaft. The design was based on the actual conditions at this site. Pipeline contractors were asked to provide cost estimates after viewing the terrain and site features. The pipeline cost listed in the capital costs was based on these estimates.

Exhibit 20 shows the routing for a gathering system from Vents \#29 and \#30 to the Parrish Shaft. This Exhibit also shows that Vents \#21 and \#22 could be readily added to the system. The main trunk line for the gathering system would follow the right-of-way already established by power lines in this region. The power lines are owned and maintained by EACC, as part of their mining operations. It was easier to obtain rights of way from surface land owners if the proposed pipelines were placed along an existing power line clear-cut area. The circuitous paths from the trunk line to the individual Vent locations follow the topographic conditions in the area. The routes were laid out in an effort to minimize pipeline installation costs.

Exhibit 21 presents a schematic design for the gathering system. This includes results of pressure drop calculations that provide the basis for sizing the vacuum blower which were installed at the Parrish shaft. The vacuum blower had a discharge pressure of $110 \mathrm{kPa}$ (16 psia), which is sufficient for fuel delivery to IC engines. The vacuums imparted on each Vent are identified in the Exhibit. Valves were placed at each vent so that the vacuum could be modified, as needed, in order to maintain the methane concentration at desired levels. The specific wellhead configuration for Vents \#29 and \#30 are provided in Exhibits 22 and 23, respectively. This shows the detail of design which was developed for this project.

The gas from the gob vents was drawn to the Parrish shaft site through the pipeline described above. Exhibit 24 shows the detail design for the system which received the gas at the shaft site, compressed it and delivered it to the generators. The positive displacement blower had a discharge recirculation loop for pressure control. The gas needed to be cooled off after compression. This was accomplished with underground piping which allows for heat dissipation to the earth. 
EXHIBIT 20. Gob Gas Gathering System Surface Routing

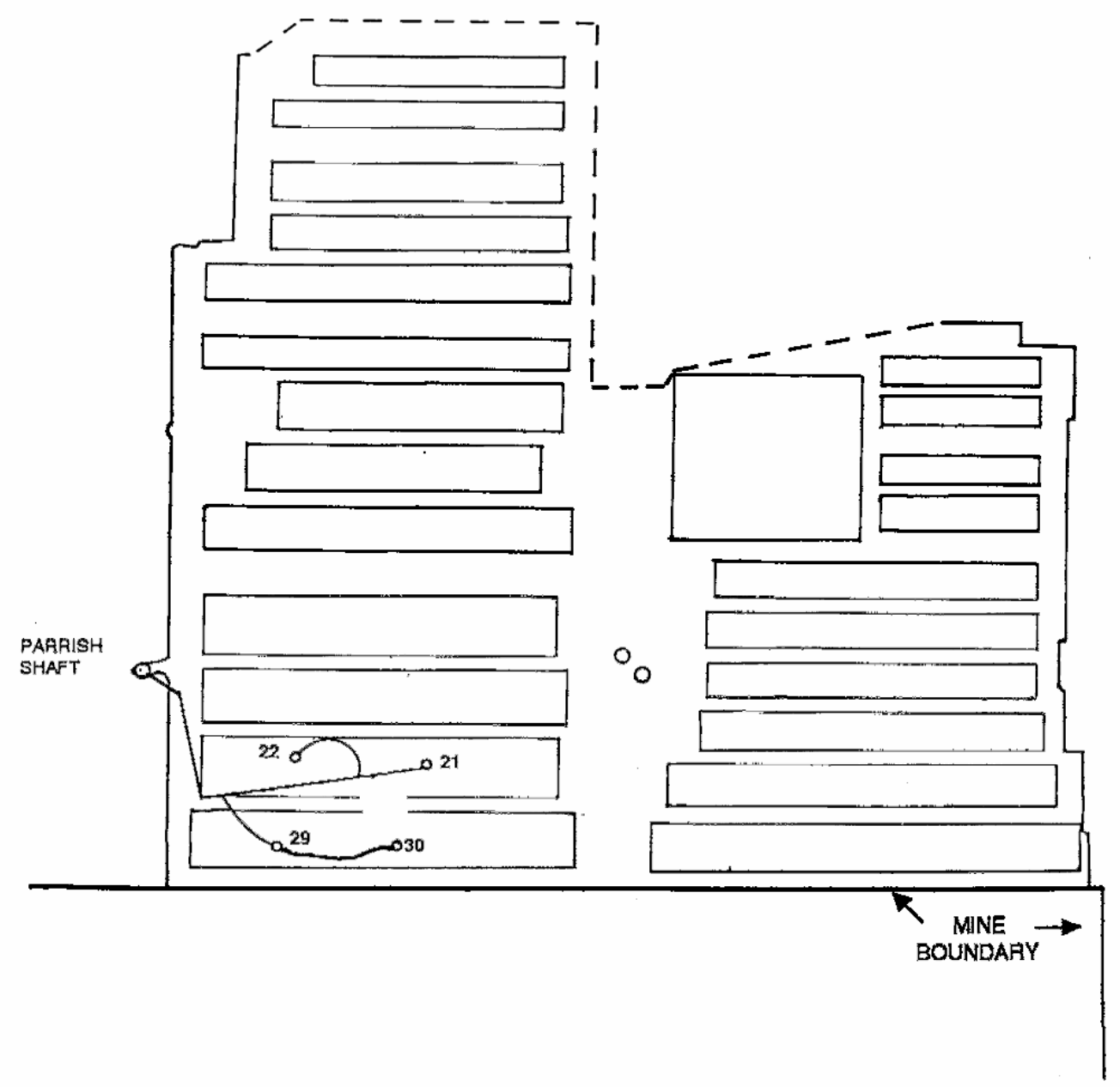


EXHIBIT 21. Pipeline Schematic Pressure Profile
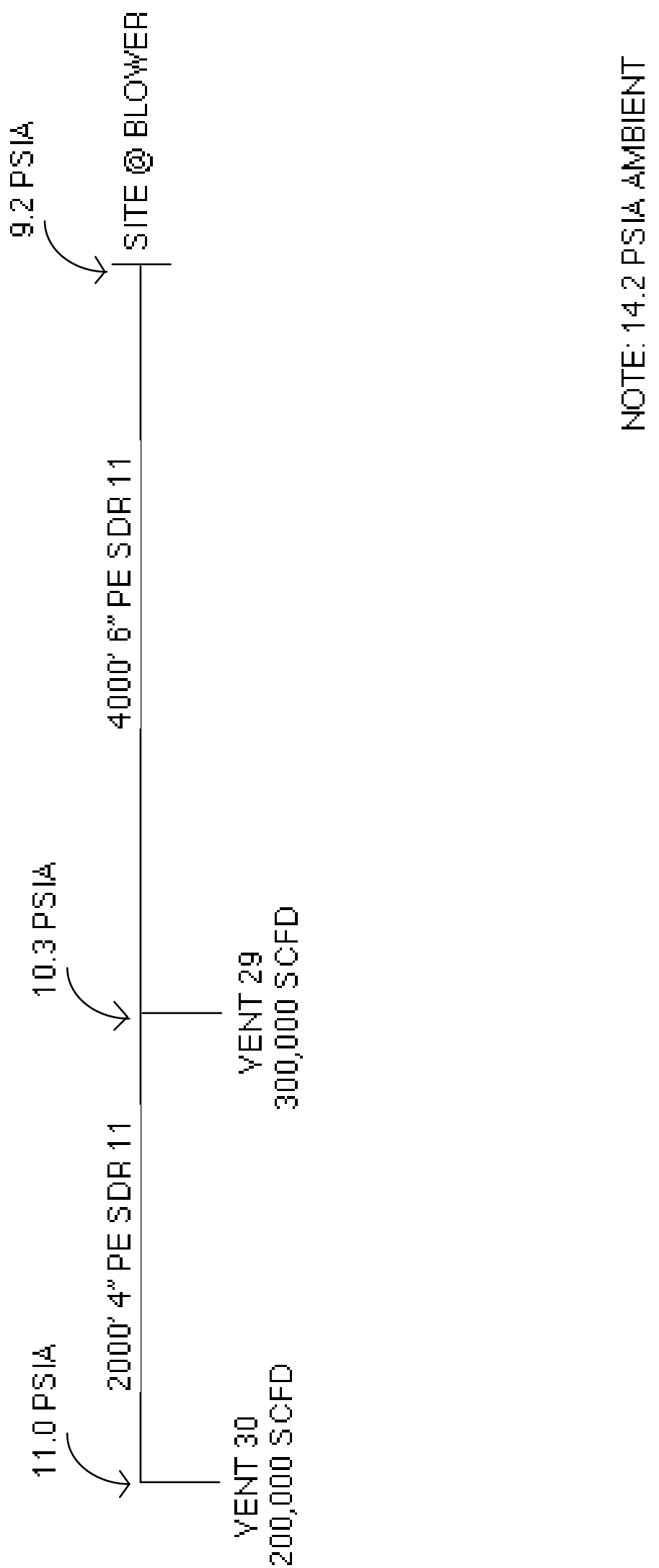
EXHIBIT 22. Vent \#29 Wellhead Configuration

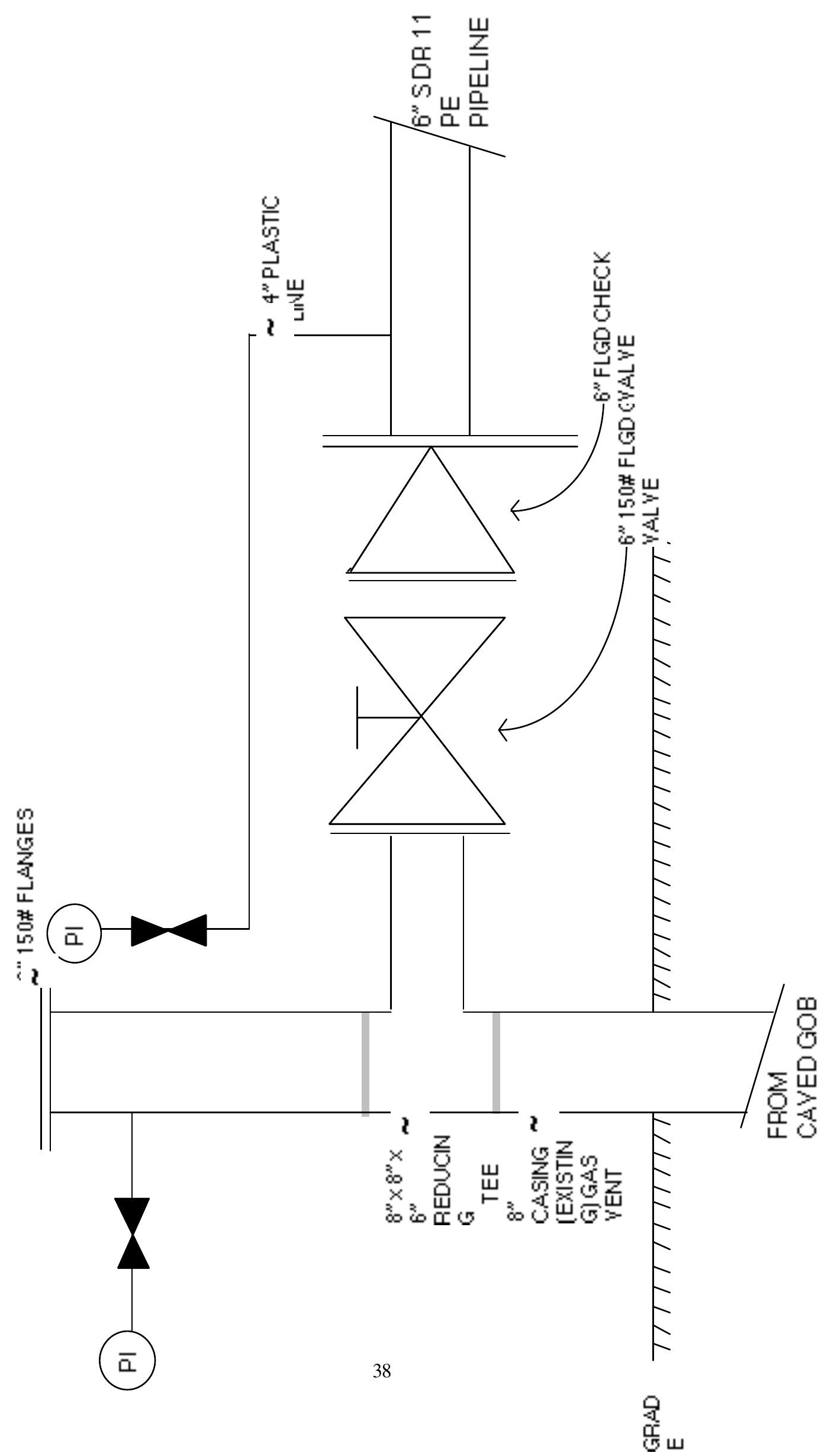




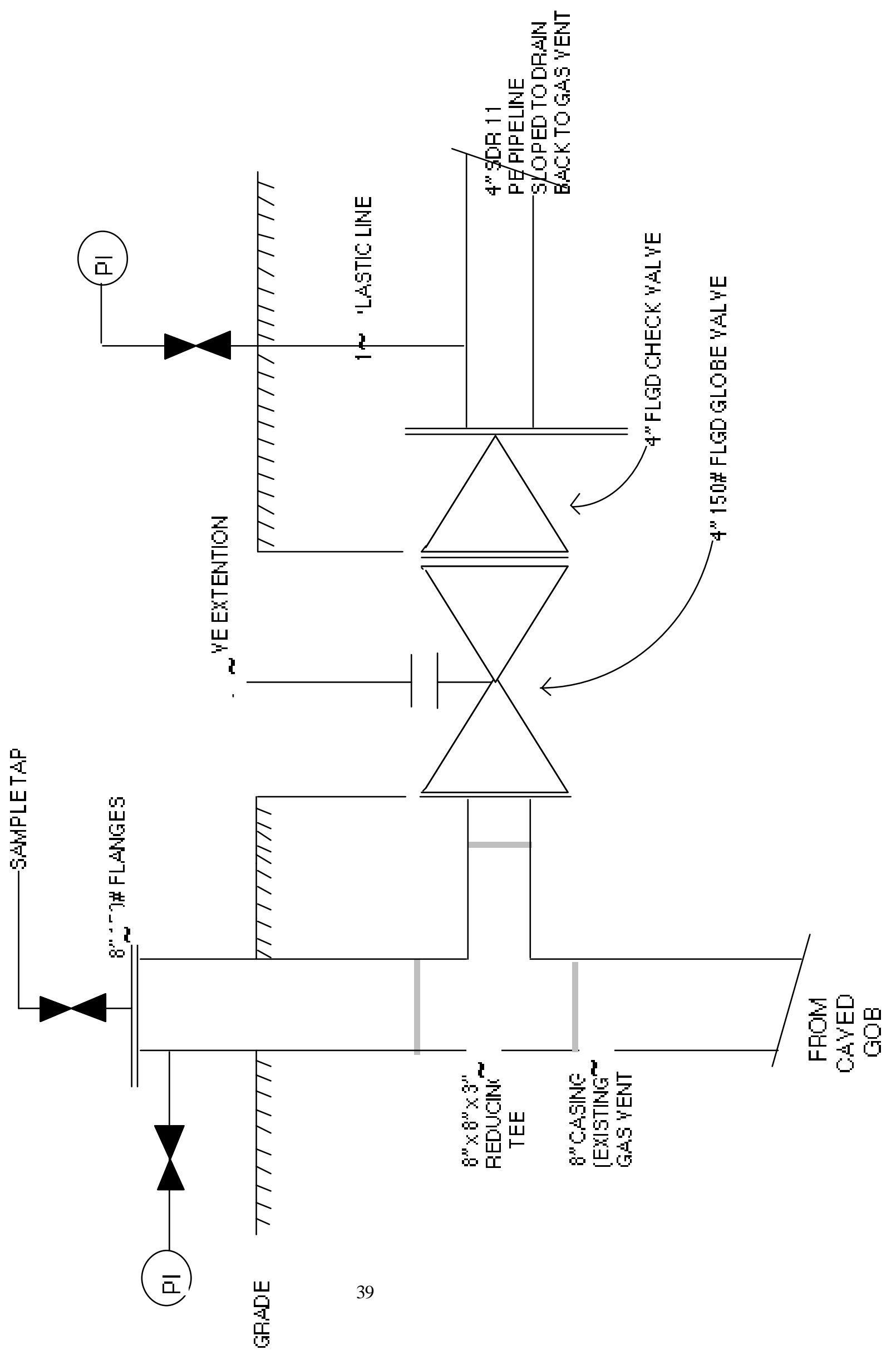




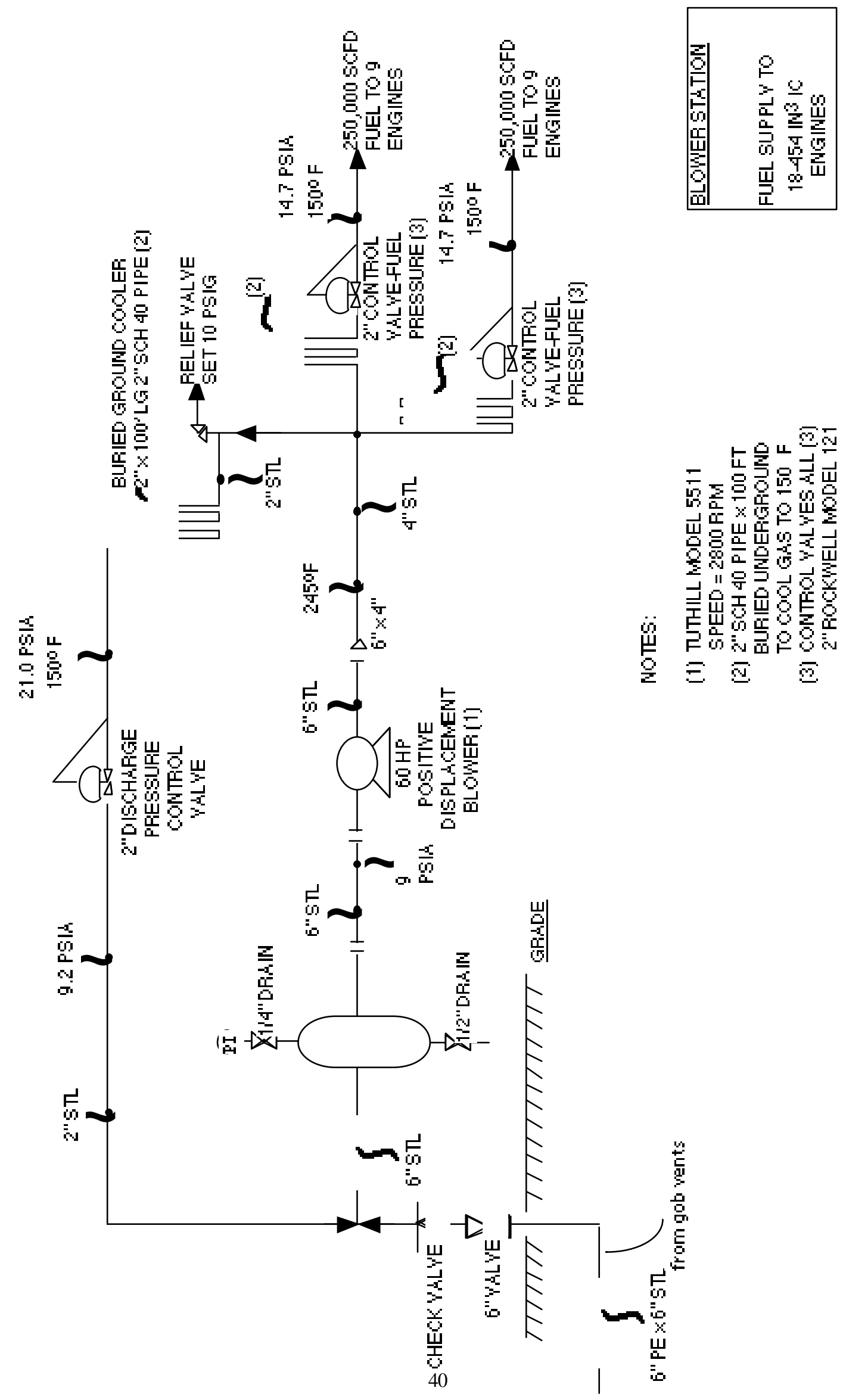




\section{Generating Equipment}

A complete list of the equipment in the power generation system is provided in Appendix C. This includes site preparation, electrical hardware, fuel supply pipeline and engine/generator sets. The sections below describe the nature of this equipment and its installation.

\section{a. Siting Logistics/Site Development}

It was decided in Phase I that it would be advantageous to locate all power generating equipment at a mine air shaft. This is in lieu of placing some of the IC engines at individual vent hole locations. The main advantage was that power lines from the individual vent holes to deliver the electricity to the Parrish subs-station would be more expensive than the gas pipelines. And there would be the need for transformers at each vent in order to deliver power at a higher voltage for long distance (over a few hundred feet) delivery.

Visits to the site showed the difficulties in trying to locate the IC engines at the vent hole locations. Installation of the generating units at the distributed sites would require considerable hauling over very poor, and sometimes steep, roads.

The maintenance on the IC engines would also be expensive. The service staff would have to go to separate individual sites. It would have required several trips to dispersed sites: for diagnostics, acquisition of parts and then return in order to make the repair. Having to access each site on a daily basis for monitoring and maintenance would make the distributed generation approach unfeasible.

Once it was discovered that a given vent could not produce the anticipated amount of CMM, the installed generation would have to be moved to another location. This provided another distinct advantage for the central generating approach.

For all of these reasons, it was deemed preferable to locate all of the generating units at a central location.

The layout for the Parrish Shaft site is presented in Exhibit 25. There are hills to the northwest and northeast. The gravel road on the west provides ready access to the generator compound. The Parrish shaft lies approximately 100 meters to the east.

Very little grading was required at the site. The slope is gradual and drops slightly towards the south. A chain link fence was installed around the generator compound. A grounding field was installed under the compound for electrical protection.

\section{b. Internal Combustion (IC) Engine Prime Movers}

NW Fuel has considerable experience with IC engine power generation at coal mines. It is the only Company in the U.S. that has successfully fabricated, installed and operated such units.

The generating units that NW Fuel fabricates and installs are modular. They include all of the required equipment for fuel combustion and power generation. The electrical switchgear required by the serving electric utility are built into a separate skid-mounted unit. Typically, these include a wide variety of 
EXHIBIT 25. Generator Site Layout

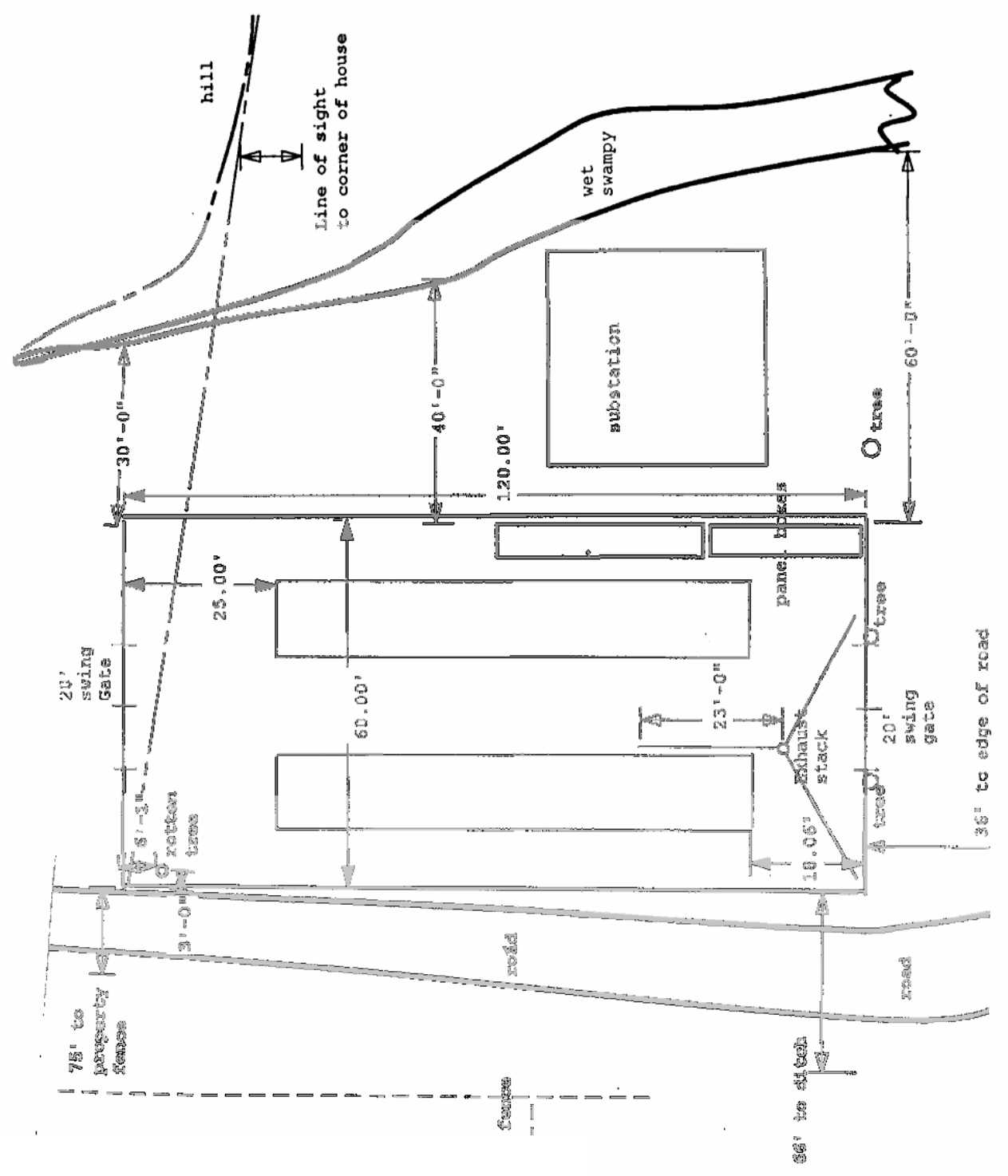


protective relays which will take the units off line if there are any problems with the utility system. In the present case, the serving utility, Allegheny Power systems did not going to require many relays, due to the nature of NW Fuel's generators, i.e. induction rather than synchronous. A de-energized utility system would take the NW Fuel induction generators off line so that the utility repair staff members are not placed in harms way. A reverse power relay was installed on the serving EACC sub-station, as extra insurance that there would not be any hazard from NW Fuel's gensets.

A control panel protected the units from internal problems, such as loss of oil pressure in the engines, overheating and excess vibration from worn bearings.

NW Fuel's basic unit is $75 \mathrm{kw}$ in size. The units are skid mounted for ease of delivery. Shop fabrication is also lower cost than field construction. The skid mounting feature allows easy relocation of units from one mine to another as business conditions change.

The engine-genset layout within the fenced compound is shown in more detail in Exhibit 26. This area was able to accommodate all 18 engines.

The engines that were used are manufactured by General Motors. They have a 7.3 liter (454 in3) displacement. They drive an $100 \mathrm{hp}$ electric motor at a speed of 1,800 rpm through direct 1:1 couplers. Each modular unit has controls to protect for overheating, low oil pressure, vibration and overspeed. The schematic diagram for this control system is depicted in Exhibit 27.

\section{c. Electrical}

The Parrish Shaft had an existing sub-station, which brought power to the site when the fan was in operation. The sub-station reduces the voltage from 23,000 to 4,160 volts. Since NW Fuel's generators produce power at 480 volts, an additional transformer was needed. The design called for the installation of a secondary sub-station with the necessary transformer. The location for this installation was already identified in Exhibit 25.

Main breakers were installed between the secondary sub-station and the generators. The optimized design called for two breakers, each serving nine engines. Two breakers were chosen over a single breaker for a variety of reasons. Cost was a significant element. Electrical hardware for a given voltage rating do not have economies of scale. A single large breaker was not found to be lower cost than two small breakers. The two breakers also have the advantage that an entire bank of engines can be operating while the electrical systems are being maintained on the parallel bank.

Allegheny Power systems was accommodating in their protective relay requirements. They only required a reverse power relay at EACC's sub-station in order to guarantee non-flow of power if the APS lines are down. This saved considerable money in not having to install over-, under-frequency and other relays at the site. The total protective relay system is shown in Exhibit 28 .

The balance of electrical wiring required to hook up all of the individual generators was relatively simple. Exhibit 29 was drawn in order to allow for a good estimate of all the wire required to make those connections.

The generators are $100 \mathrm{hp}$ motors, run at faster speeds, so they become electrical generators. The control wiring for the generators is presented in Exhibit 30. This Exhibit shows that each generator has a capacitor added. 
EXHIBIT 26. Engine/Genset Layout

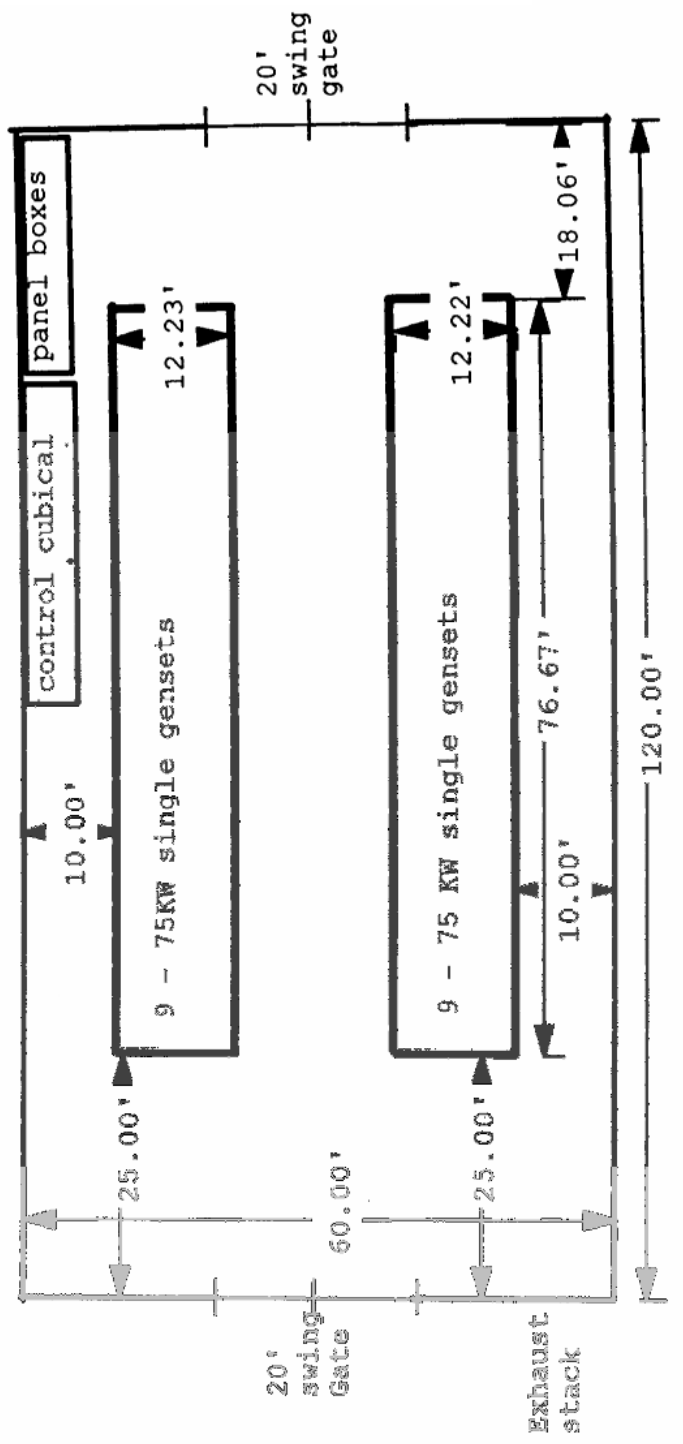


EXHIBIT 27. Engine Control System

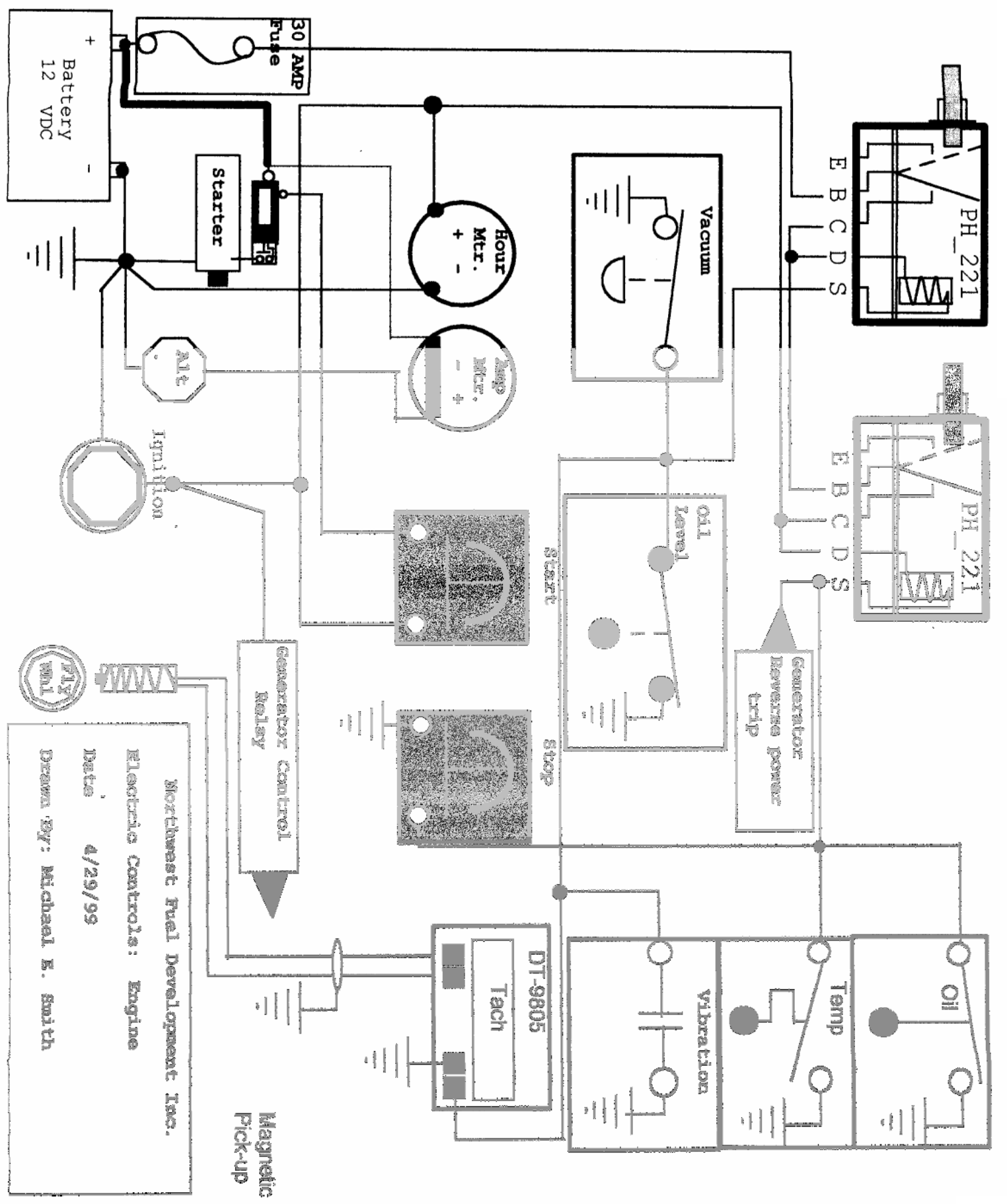


EXHIBIT 28. Protective Relay One-Line Diagram

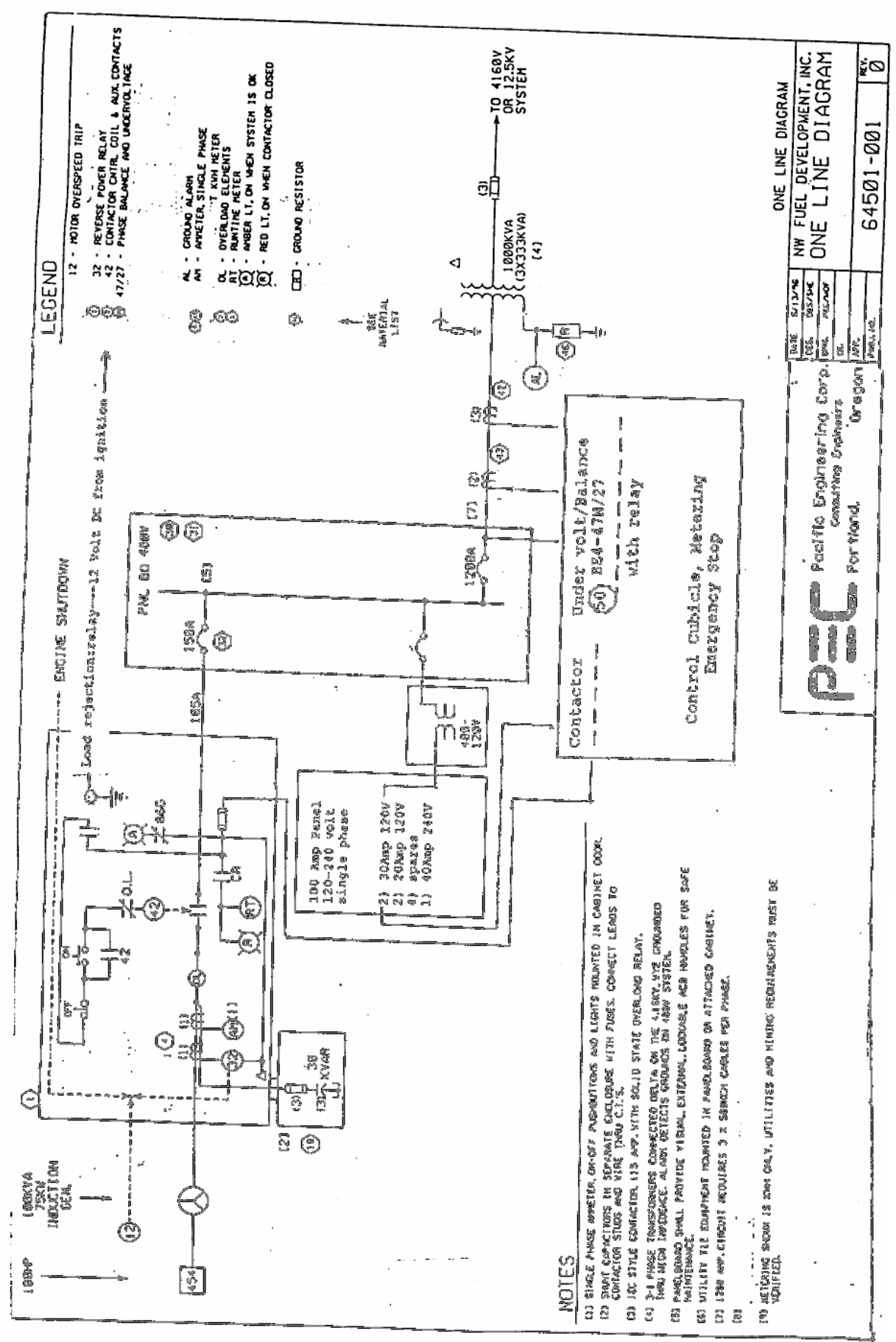


EXHIBIT 29. Layout for Estimating Wire Requirements

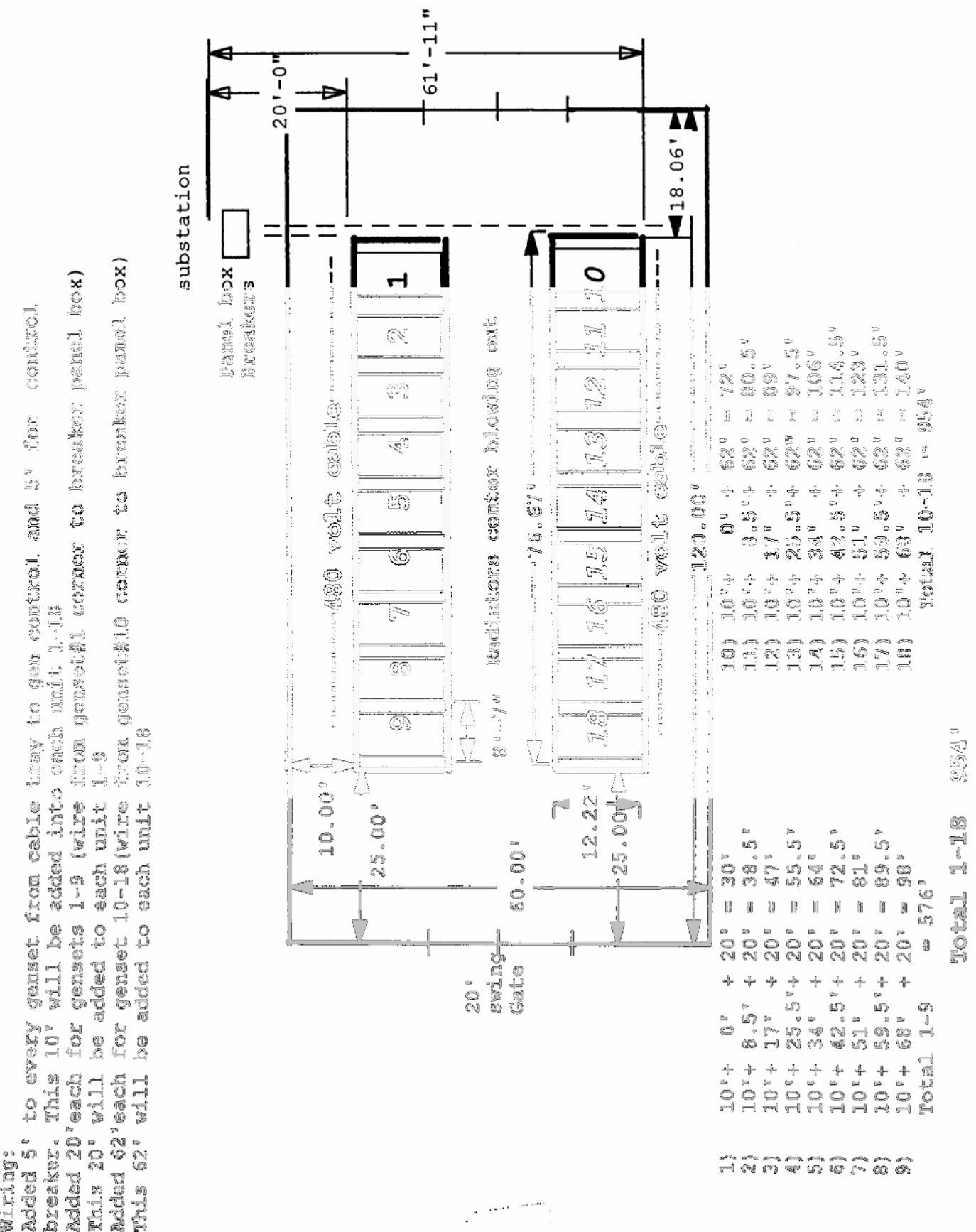


EXHIBIT 30. Generator Electrical Controls

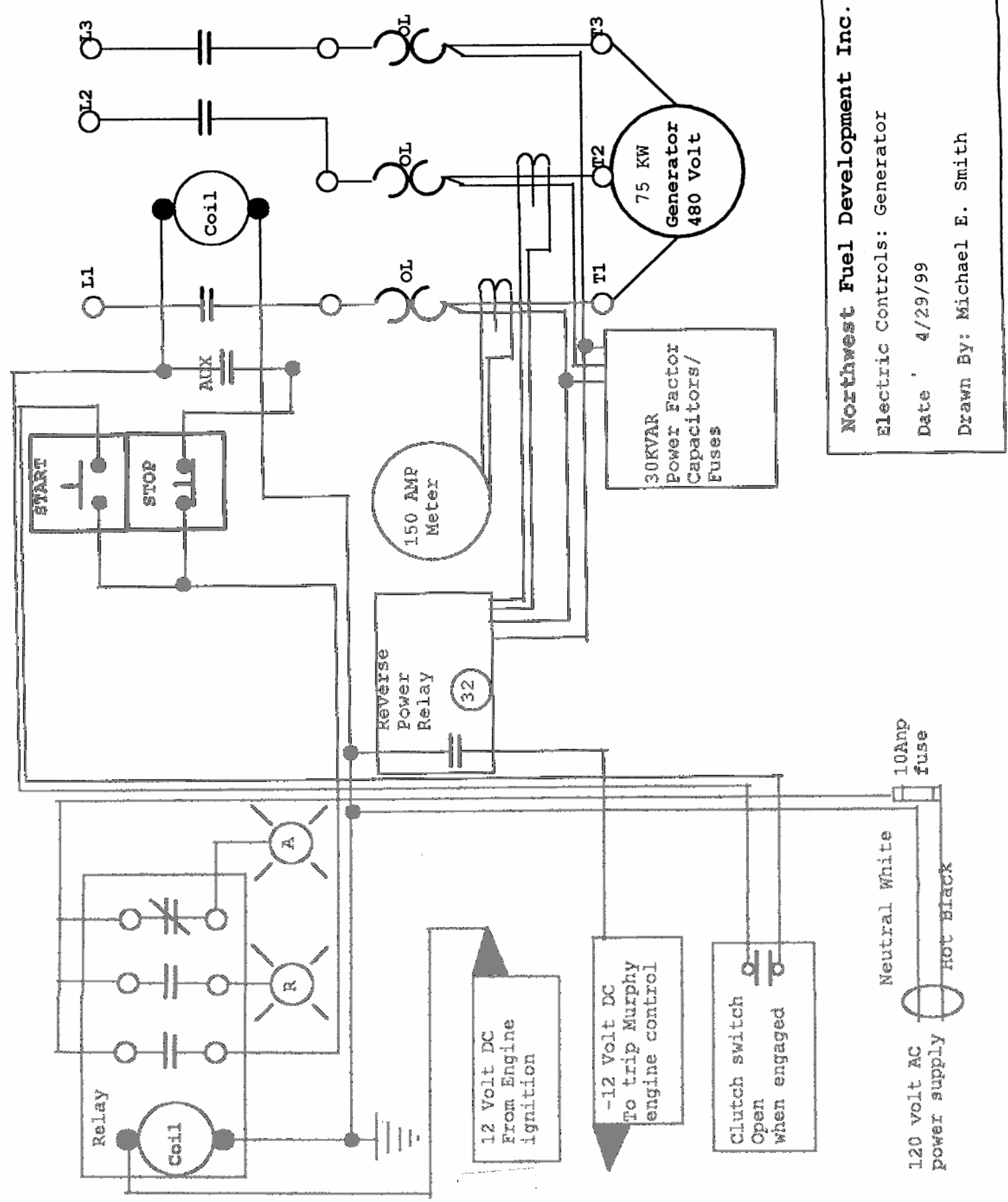


This capacitor will correct the power factor for the generator. Since the induction generators consume kvar's during their operation, the capacitors will become the source for the kvar's. In that fashion, APS would not be charging for the consumed kvar's.

\section{d. Exhaust}

During Phase I, the plan was to exhaust the combustion products from the engines directly into the atmosphere. Because of air emission permitting considerations, a common exhaust stack had to be installed. The exhausts from all of the engines were manifolded together and brought to the 30 meter (100 foot) stack. The design for this stack is shown in Exhibit 31.

The exhaust gathering system is shown in Exhibit 32. This system moves the exhaust gases from the engine outlets to the stack. The Exhibit shows that the pressure drops in the system were anticipated in specifying the line sizes. Even the temperature of the gas was considered in evaluating the various blower options that were available for moving the exhaust gas through the piping, especially as they related to use in high temperature gas.

\section{e. Air Shaft Emissions for Combustion Air}

After the Parrish Shaft was to be re-activated it could have been the source for additional methane to fuel the engine-generators. The shaft was to be used beginning in 2000 or 2001. At that time, ducting was to be installed to bring the shaft exhaust to the gensets so it could be used as the combustion air for the gensets.

This plan was thwarted when the mine changed the Parrish Shaft from an outlet to an inlet system. That eliminated the possible source of methane.

The following design work had been performed in Phase II and may have some applicability in other projects, so it is still presented here. The design schematic for the piping and blower required to move the air is presented in Exhibit 33. The design calls for a $1.4 \mathrm{~m}$ (18 inch) diameter duct. This is sufficient to move all the air to be consumed by the 1,200 kw of IC gensets.

It was not planned to have a fixed coupling at the Parrish shaft. The intake of the air blower would simply be placed within the exhaust stream from the Parrish Shaft fan, physically close to the outlet of the fan. By not making a "hard" connection, one can avoid any questions of mine safety related to the consumption of the exhaust air. It also avoids any significant involvement by the Mine Safety and Health Administration (MSHA). This uncoupled method would work since the air consumption by NW Fuel's gensets is less than 3\% of the total air flow from the Parrish shaft. There is so much excess air available that the inlet to NW Fuel's air blower will only take in air from the Fan and not clear air.

The outlets of the air supply were to be directed to the carburetor inlet of the IC engines. They also did not need to be firmly connected since there was to be an excess of air provided. The unused air is not hazardous, so it can be allowed to drift into the atmosphere. A fixed connection to each engine could be utilized, but that would be more costly, and cause more work during maintenance operations. 
$\square$

EXHIBIT 31. Exhaust Stack Design

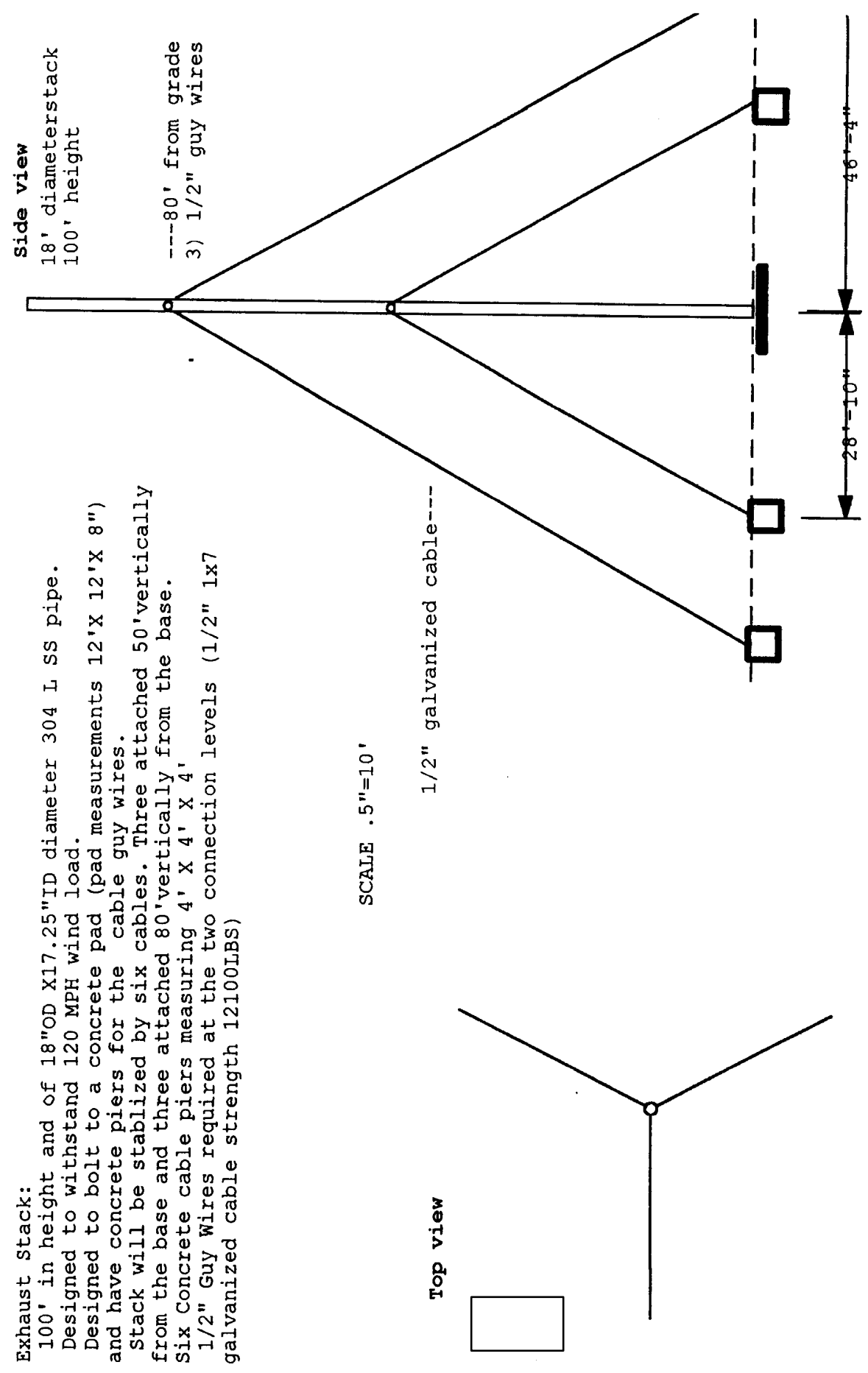


EXHIBIT 32 . Exhaust Gathering Line Design

Fed No. 2 Exhaust Gas Pressure Profile

From Engines Exhaust Headers Through

The Stack To The Atmosphere

Design Basis: Vacuum at Engine Exhausts

Pressure at Top of 100 FT

Stack $=14.087 \mathrm{psia}, 1170^{\prime}$

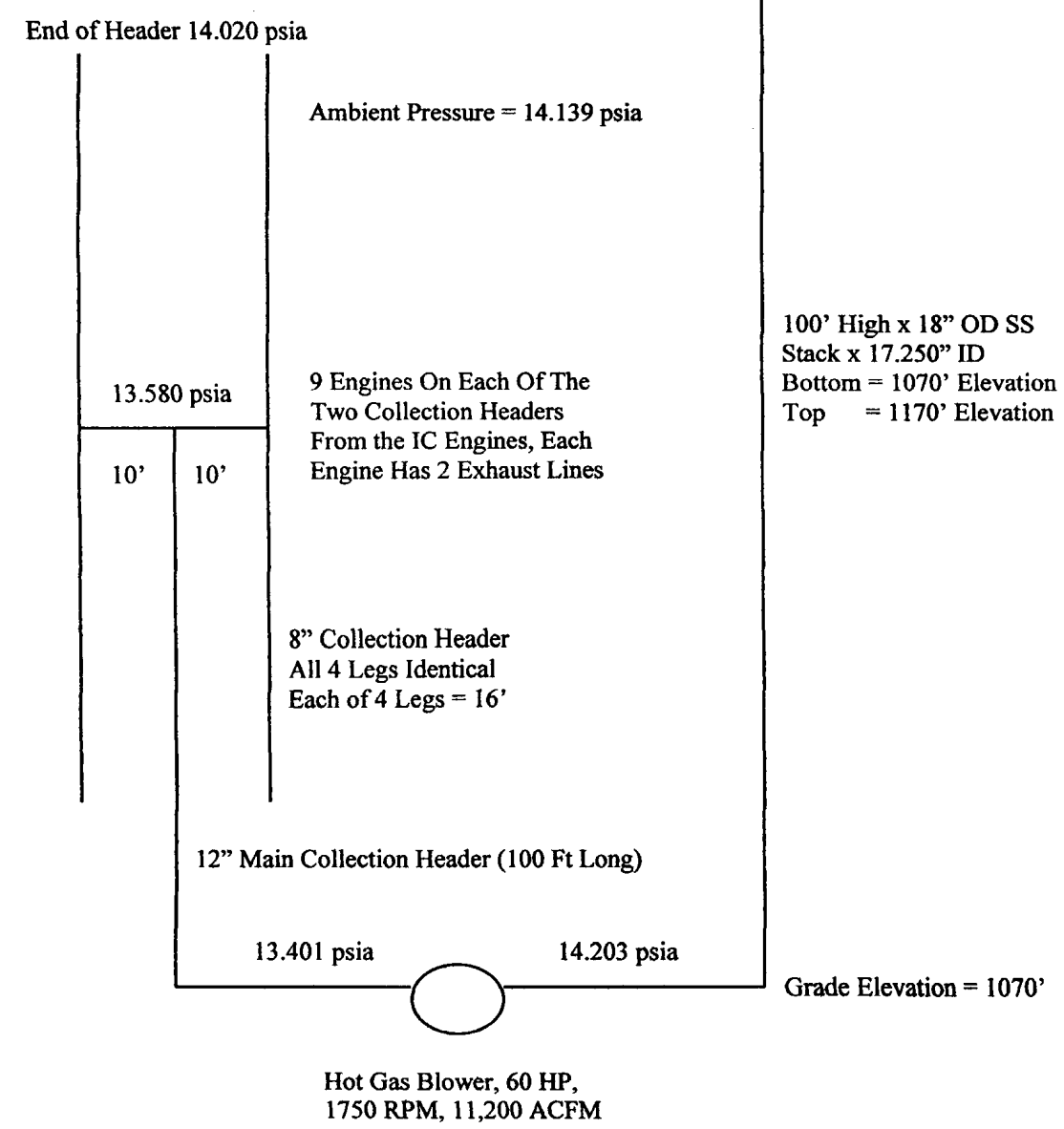


EXHIBIT 33. Piping \& Equipment for Combustion Air

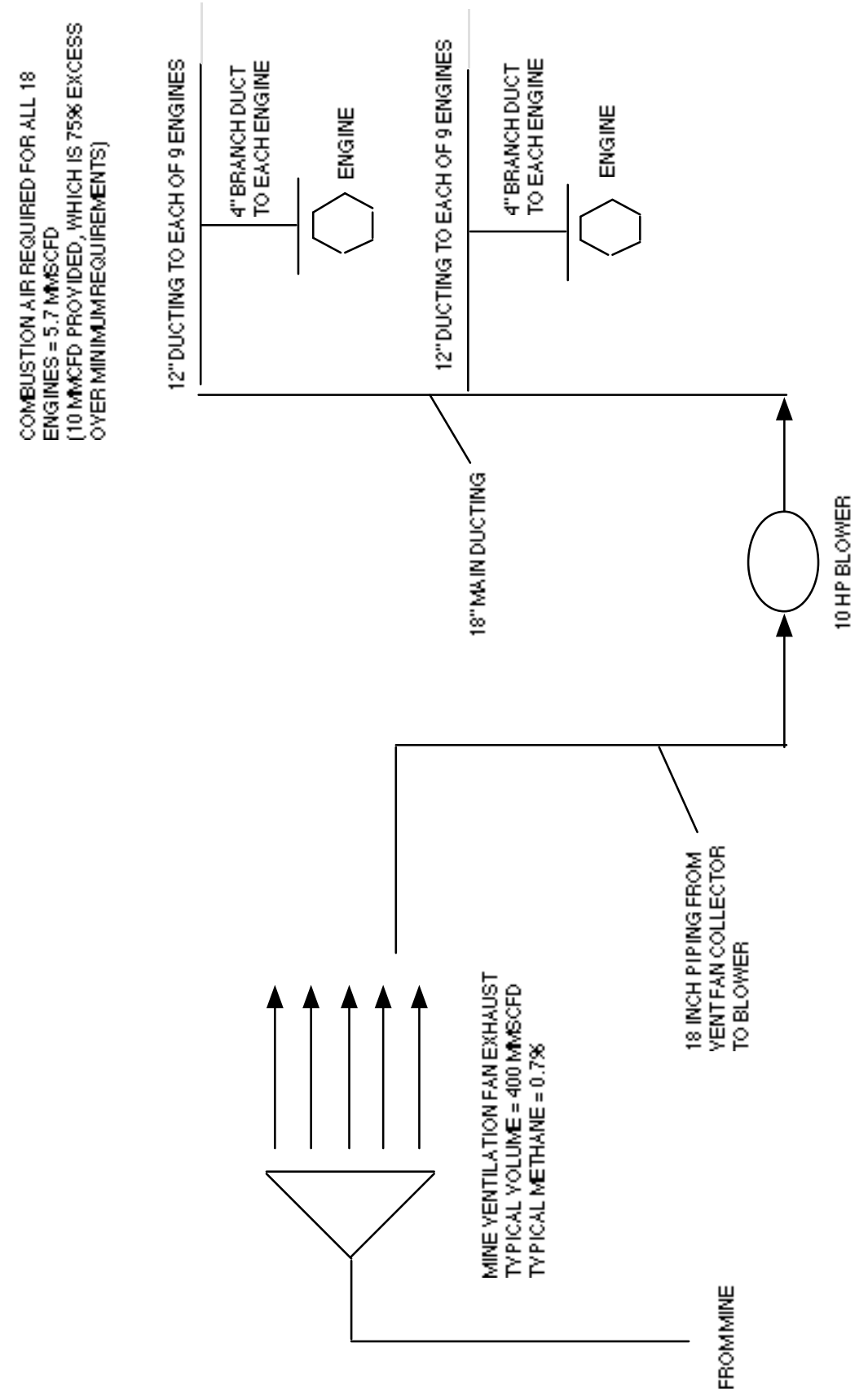


For some installations one could consider fixed connections to supply air for each engine. That would allow for turbocharging of the engines. If the air supplied is at a higher pressure - along with comparably more fuel - the engines will be driven harder, providing more generating capacity. In order to take advantage of such an approach, larger generators would have to be used with the engines. All of the electrical hardware would also have to be comparably re-sized.

\section{Gas Processing}

Any gas that is close to being pipeline quality was to be processed and delivered to a pipeline. This conclusion was drawn from a simple analysis of potential revenues versus costs for the various technologies. The power generating project could be installed for about $\$ 600$ per kw. That can be converted to $\$ 90$ of capital cost per $\mathrm{m}^{3} / \mathrm{min}$ ( $\$ 1.80 /$ MMCFD) of methane gas used. For a conventional PSA process the equivalent capital cost value is less than $\$ 50 / \mathrm{m}^{3} / \mathrm{min}(\$ 1.00 / \mathrm{MMCFD})$ and for a CPSA process it drops to $\$ 30 / \mathrm{m}^{3} / \mathrm{min}^{\mathrm{n}}$ $(\$ 0.60 / \mathrm{MMCFD})$. Even if one were to re-calculate the PSA costs per volume of product, rather than feed, the values are still about $1 / 2$ or less than the power generating capital costs.

The gas delivery option also needs $\mathrm{CO}_{2}$ removal and dehydration. These may modify the cost ratios somewhat, but they will not change the overall conclusion.

In like fashion, the operating and maintenance costs for PSA process options are one-half or less of those for power generation. These capital and operating cost comparisons are an initial indication. The economic analysis section below, confirms the higher rate of return for the gas processing options. For these reasons, it is clear that the preferred approach to using the waste methane was pipeline delivery, if that was technically viable. In this Federal Mine Project, pipeline delivery was preferable for those instances where the gas is close to pipeline quality, so the NW Fuel CPSA processes could deliver a pipeline quality product. Using the by-product stream from the PSA process for fuel in generators optimizes the total system.

\section{a. Nitrogen Rejection Unit (NRU)}

As noted above, NW Fuel has two process options for removing nitrogen from waste methane to make it suitable for pipeline delivery: PSA and CPSA. The conventional PSA process is more efficient, and can remove higher levels of nitrogen. The CPSA is a simpler process and can process much higher flow rates at a low cost, but is limited to about 30\% nitrogen removal from the feed gas. Given the initial quality of the Vent 29 gas, it was decided to install the CPSA system. Unfortunately, the subsequent drop in gas quality made this system unsuitable for commercial operation. The process could be shown to be technically viable, but it could not produce a commercial product from the low quality gas that was available.

\section{(1). Pressure Swing Adsorption (PSA)}

The conventional PSA system is depicted in Exhibit 34. The adsorption vessels concentrate the methane gas and reject the nitrogen through a series of batch operations. The batch operations pressurized and depressurize the gas on and off an adsorbent. This concentrates the methane and rejects nitrogen. The two parallel adsorption vessels, along with associated surge tanks, allow for relatively continuous production of product. 
EXHIBIT 34. PSA Process Diagram

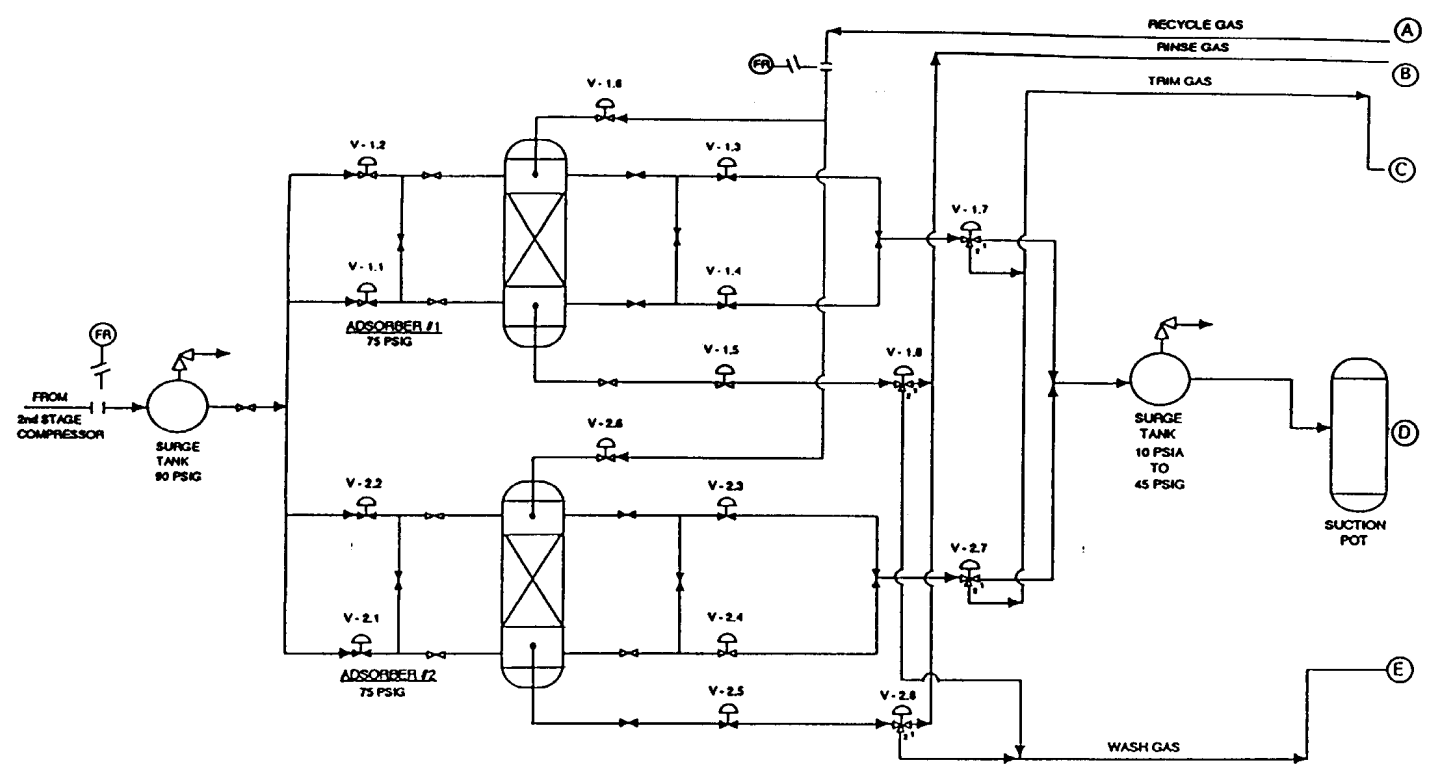

(A)
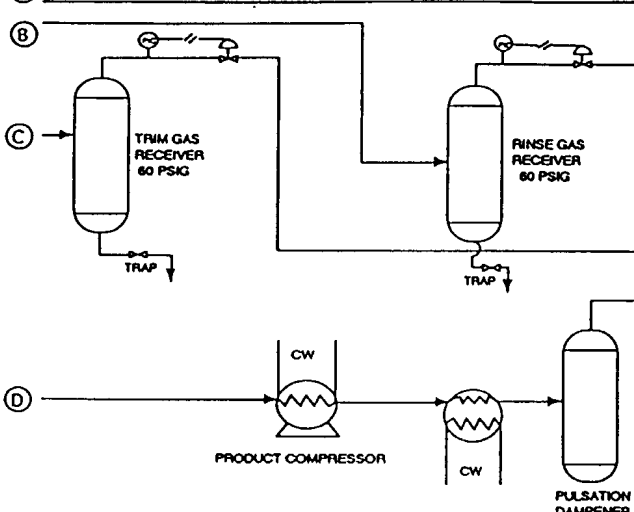

$9-1-2$
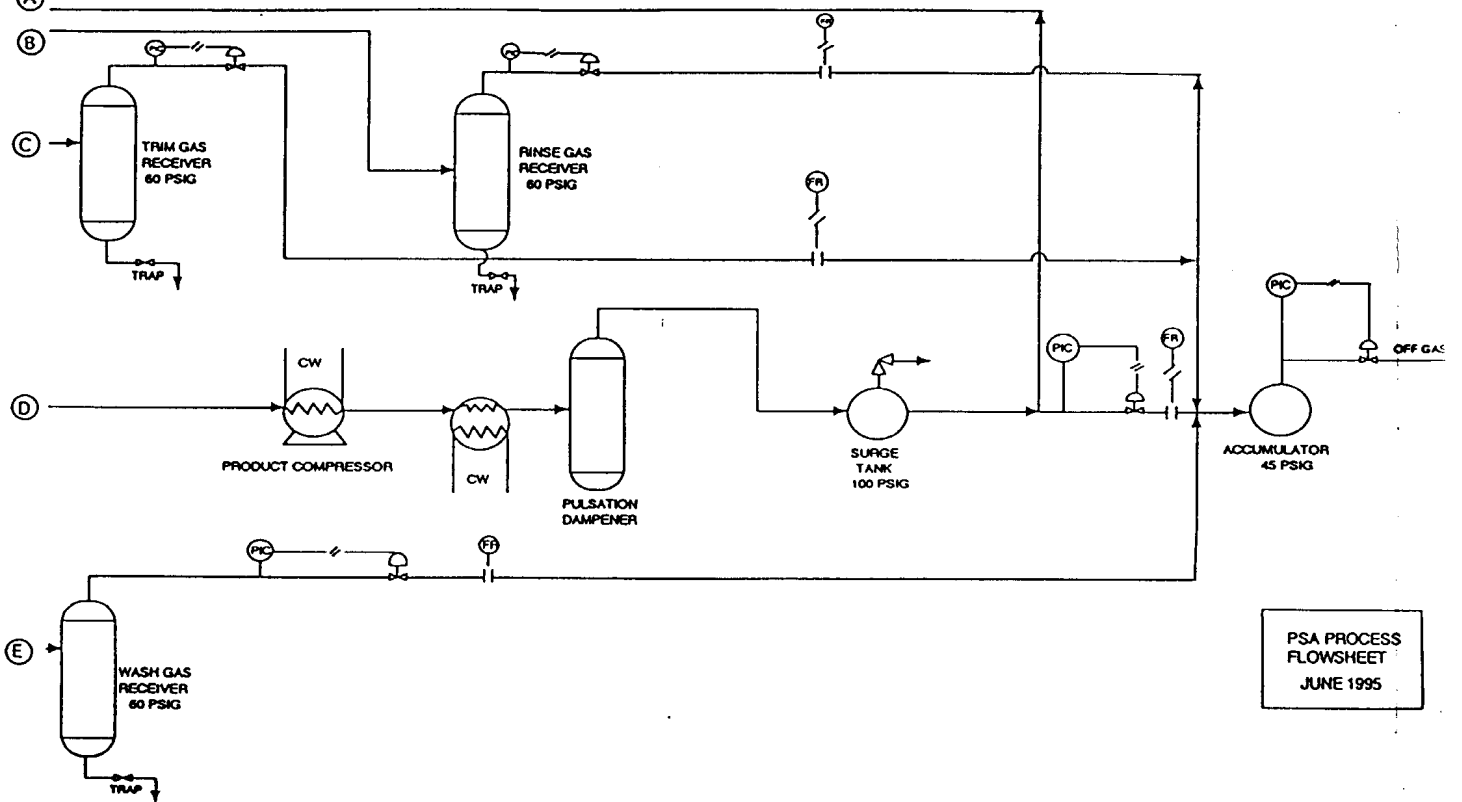


\section{(2). Continuous Pressure Swing Adsorption (CPSA)}

The Continuous PSA (CPSA) process is technically also a batch operation, but it cycles so rapidly that it virtually becomes a continuous process. Surge tanks are only used on the feed stream, and they are considerably smaller than the comparable PSA process vessels. This system is shown in Exhibit 35. The adsorption vessels and surge tanks, on a $20 \mathrm{~m}^{3} / \mathrm{min}$ (1 MMCFD) CPSA Unit are about the size of a pickup truck. The comparable PSA unit is several times larger.

\section{b. $\mathrm{CO}_{2}$ Removal}

There were two principle process options for $\mathrm{CO}_{2}$ removal: amine scrubbing and PSA. The amine absorption systems are very common in natural gas applications. A significant limitation to this process is the possible occurrence of oxygen in the feed gas. The gob wells can have small amounts of oxygen. If the vacuum pipeline system develops a leak that would be an additional source of oxygen. The oxygen chemically bonds with the amine in solution and forms organic acids which attack the steel pipe and vessels in the process unit. It may be too expensive to remove the oxygen. There are additives that can be placed into the amine solution to inhibit the acid formation. If that is done, then the amine will need to be replaced, or reclaimed, periodically.

The amine system has a second concern. The local gas pipelines operate at pressures below $450 \mathrm{kPa}(50 \mathrm{psig})$. The absorption equilibrium between $\mathrm{CO}_{2}$ and the amine solution is better at high pressures. That would add to the cost of the amine system since the pressure would be lost upon gas delivery to the pipeline. The absorbers will work at the lower pressures, but the equipment capacity will need to be lowered.

The alternative is to use a PSA process for $\mathrm{CO}_{2}$ removal. The process is not as efficient as the amine, but it does not have the oxygen, nor high pressure limitations noted for the amine system. The PSA benefits did not outweigh the low cost of an used amine system. That led to the use of an amine system.

\section{c. Dehydration}

A similar choice occurs for dehydration of the gas. The common tri-ethylene glycol (TEG) system benefits from high pressures. That generates a cost penalty for applying such a process in this particular case. The simple alternative is to use salt tablets in a closed vessel to absorb the water from the gas. This system was used successfully by DEPI in the north end of the Mine for their gob gas delivery. The TEG system was chosen as the process for the dehydration.

\section{Phase III Operating Results}

\section{Power Generation}

After the complete installation of the 1.2 MW of power generating units, they were operated at the maximum capacity allowed by fuel availability. As noted above, the fuel supply was severely limited during the first years of operation. It was only after the western part of the Mine was sealed that the Grout Pipe was able to supply more of the available generators with fuel. Exhibit 36 provides a tabulation of the power that was generated during the project life. The generation has even increased after the termination of this project, with monthly average generation exceeding $800 \mathrm{~kW}$ in March 2005 . 


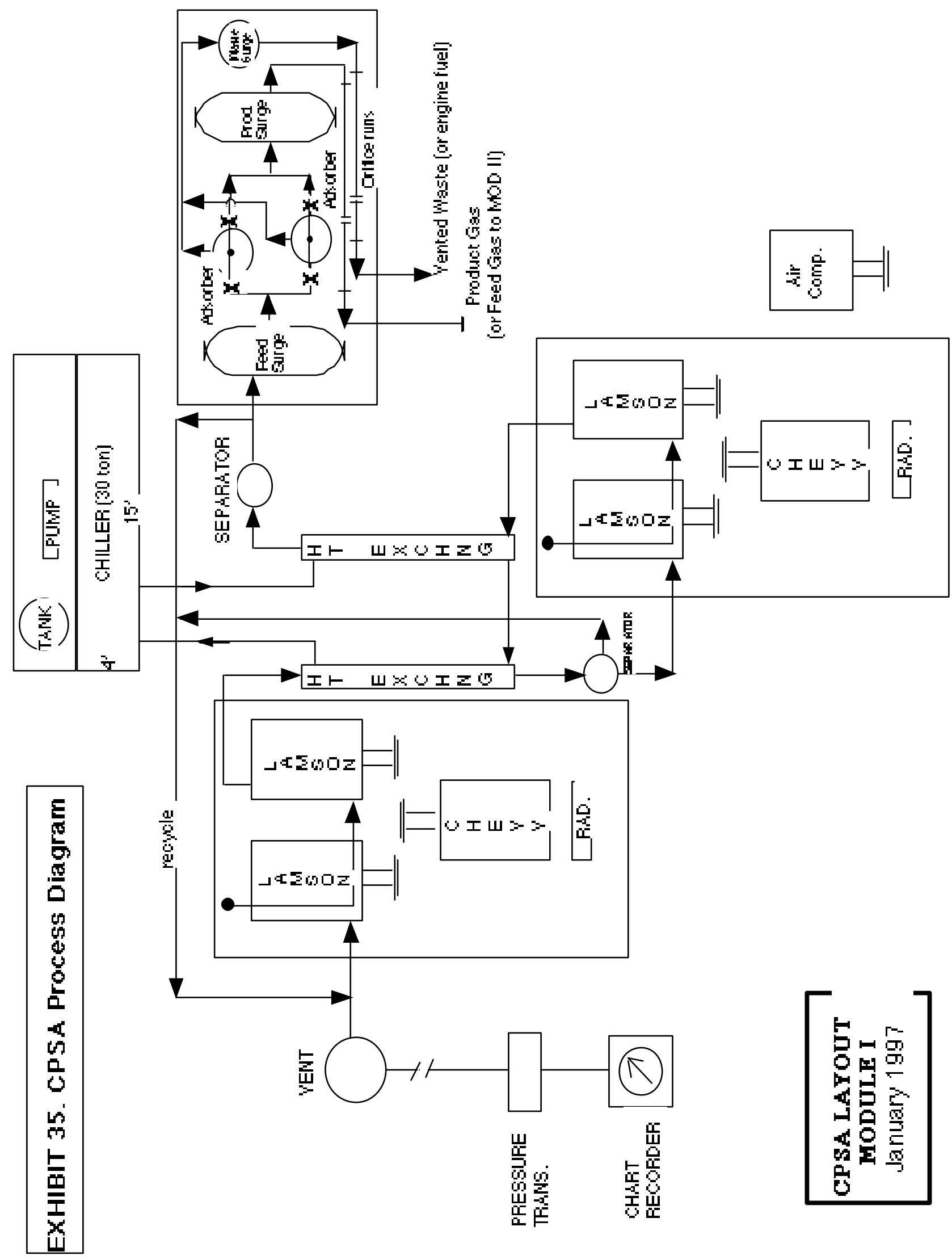


Exhibit 36. Phase III Power Generation






\section{Nitrogen Rejection - CPSA}

The CPSA was not able to produce pipeline quality gas from the available CMM. This was not a surprise since the CPSA unit is a polishing unit, capable of only removing a few percent nitrogen in cases where the CMM is nearly pipeline quality. Since the available feed gas had less than 60\% methane and more than $30 \%$ nitrogen, it would not be possible to meet the $4 \%$ maximum N2 specification for pipeline quality gas.

The CPSA process is actually unusual. Typical chemical processes can perform more effectively when they are provided a low quality feed stream. A typical nitrogen rejection process would become less effective when one delivers relatively high quality gas to the process. One would expect a lower percentage of the nitrogen to be removed. The CPSA process is actually less effective when a low quality CMM stream is supplied. That is why it is not surprising that the nitrogen removal capabilities, as tested in this project were only $10 \%$ to $18 \%$ of the feed stream nitrogen. When CMM streams containing $90 \%+$ methane have been processed in the CPSA, it has been able to remove over $30 \%$ of the nitrogen from the feed stream. The actual results form the tests are described below.

The CPSA unit was started on June 15, 2004. The test results are summarized in Exhibit 37. There were no surprises from the results. The only test that may have been slightly out of step with the others was the first one, possibly a startup issue since the data were taken after the unit had been on line for an hour. Tests 2 \& 3 are the same, with Test 3 data from the following morning, after the unit had run overnight.

The field data were modified by correcting the methane readings. A GC analysis of a sample showed that the Anarad instrument was reading considerably lower $\mathrm{CH} 4$ than the actual content. The Siemens instrument provided relatively accurate $\mathrm{CO} 2$ readings. The Corrected $\mathrm{CH} 4$ readings are a proportional correction of the raw data from the Anarad using the GC analysis.

Material balances were based on the concentrations in the various gas streams. This allowed for calculation of the amount of feed that went to the product (Gas Recovery) as well as the individual component recoveries (CO2 and CH4).

The trends were what one would expect for the CPSA.

- Increased cycle time provides higher N2 rejection (comparing Test $3,4 \& 5)$.

- Increased cycle time yields lower CH4 recovery since the waste stream is continually emitting waste gas during the adsorption and desorption steps. This is not easy to review in the attached spreadsheet, possibly due to the brevity of some of the tests.

- Restriction of the waste stream causes lower N2 rejection and higher CH4 recovery. In Test 6, apparently very little of the feed gas was allowed to escape through the waste line.

Comparing these results with those from previous runs of the CPSA, one can reaffirm another conclusion that had been observed before:

Lower quality feed streams are less desirable for the CPSA. 
Exhibit 37. CPSA Test

Results

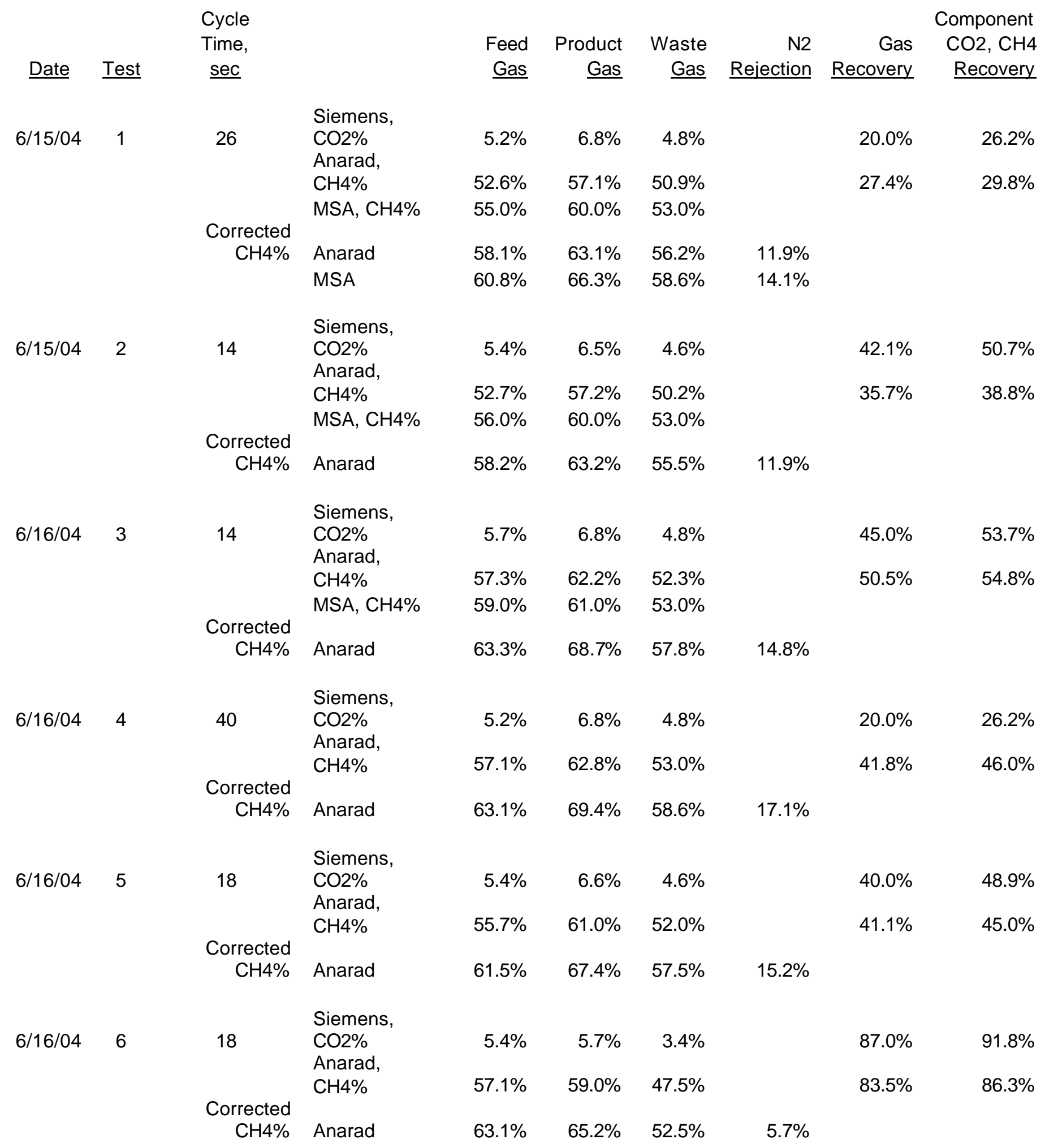


Unlike other chemical and separation processes, a higher quality feed stream actually leads to a higher percentage of N2 rejection. One can actually state that the operation of the CPSA is counter-intuitive.

The current results are consistent with this observation. The best N2 rejection was about $17 \%$. Earlier results with higher quality feed streams (about 85\% $\mathrm{CH} 4$ ) allowed for $\mathrm{N} 2$ rejection of $30 \%$ and better.

Based on the Tuthill BlowerXpert7 Program the total flow of CMM through the blowers was approximately 1.08 MMCFD. Given the feed stream analysis, that yields 650 MCFD of CH4. These blowers were feeding the gensets at the site simultaneously with the CPSA. With 9 engines operating, about 225 MCFD of CH4 was being consumed for power generation. That left 425 MCFD for feed to the CPSA. The Gas Recovery values in the attached spreadsheet could then be used to calculate the Product and Waste stream flow rates if desired.

After the tests listed in Exhibit 37B, the CPSA unit was run continuously for several weeks. There were no significant operating issues during this extended operating period. That showed that the process is commercially ready if there is higher quality CMM available for processing.

\section{E. Economic Analysis}

\section{Federal No. 2 Mine Electricity Rates}

The generated electricity was sold to EACC under a letter agreement. The Federal No. 2 Mine is served by Monongahela Power Company (Mon Power), a subsidiary of Allegheny Power Systems. The Mon Power rates break out demand and energy components separately. Power is purchased by the Mine from Mon Power under Rate Schedule $\mathrm{K}$. The demand charges are $\$ 8.268 / \mathrm{kva/month}$ for the first $1000 \mathrm{kva}$ and $\$ 6.925 / \mathrm{kva} / \mathrm{month}$ for all additional kva. The demand is based on the highest 15-minute peak during the monthly billing period.

These rates declined about 5\% during the execution of the project. It is a credit to the proposed technology that it continues to be competitive in light of these price drops.

Since a mine-site generator would only be displacing incremental demand, the rate at which it could sell to the coal company would be less than or equal to the lower $\$ 6.925 / \mathrm{kva}$ per month rate. The generators have generally had greater than 90\% availability during a month. Therefore, this demand component would be equal to $\$ 0.0095 / \mathrm{kwh}$ ( $9.5 \mathrm{mills}$ per $\mathrm{kwh})$.

The energy charge under schedule $\mathrm{K}$ is $\$ 0.02304 / \mathrm{kwh}$. This encountered more than a $10 \%$ drop since Phase II was initiated. At current rates, that means an onsite generator could be displacing power valued at slightly over $\$ 0.032 / \mathrm{kwh}$ if both demand and energy components are considered.

The Mon Power Rate Schedule does not contain separate fuel adjustment clauses. Such elements are apparently handled by new rate schedule filings. There is very little concern over the total electricity market at this site. The Federal No. 2 Mine uses between 10 and 20 MW of peak demand. With the mining machines shut down, the fans alone use between 5 and 10 MW of electricity for their operation. The original Phase II proposal was to install nominally 1 MW of generating capacity. This analysis shows that there is a considerable market for more generating capacity in the future. 


\section{Power Generating Equipment Capital Costs}

Capital cost projections are for IC engines as fabricated by NW Fuel. All of the details are presented in Appendix C. This covers everything from site preparation, and electrical hardware, to engines and generators. The total capital cost was $\$ 740,000$, as is summarized in Exhibit 38 .

\section{Power Generation Operating and Maintenance (O\&M) Costs}

The O\&M costs for IC engines are based on actual costs experienced by NW Fuel during the 6-month time period from April 1, 2004 through the end of the DOE contract period, October 4, 2004. The O\&M costs, including labor, add up to $\$ 50,280$. During that time, a total of 2,204,000 kWh were generated. That leads to an operating cost of $2.3 \mathrm{c} / \mathrm{kWh}$. That is higher than expected, mainly due to high labor costs. These will come down over time as the generating units produce higher outputs and the local operator becomes more self-reliant. During the early Phase III operations, NW Fuel's Operations Manager had to drive to the site from Cadiz, OH in order to help establish the normal operating and troubleshooting protocols. As the local operator becomes more familiar with the equipment, there will be less need for remote support.

\section{Gas Processing Capital Costs}

The gas processing included a $\mathrm{NRU}, \mathrm{CO}_{2}$ removal unit and a dehydration unit. The NRU was a CPSA unit. The $\mathrm{CO}_{2}$ removal was an amine system and the dehydration was accomplished with a TEG unit.

The combined gas processing units were capable of processing $20 \mathrm{~m}^{3} / \mathrm{min}$ ( $1 \mathrm{MMCFD}$ ) of CMM. The capital costs for both the CPSA unit was $\$ 403,000$. The capital costs for an amine scrubbing unit was held to $\$ 65,000$ by purchasing an used unit. New units would have cost $\$ 120,000$ for a plant processing $20 \mathrm{~m}^{3} / \mathrm{min}$. The dehydration unit cost less than $\$ 20,000$. With delivery and installation, the total installed cost was about $\$ 35,000$.

\section{Gas Processing Operating and Maintenance (O\&M) Costs}

The operating costs for the NRU and other gas processing units was not determined. The inability to produce a pipeline product from the available low quality gas kept the NRU operation from being continuous. The unit was tested for a short period of time and then shut down.

\section{Discounted Cash Flow Analysis}

Using the Capital and operating costs stated above, one can perform a discounted cash flow (DCF) return on investment (ROI) analysis for the power generating installation. Unfortunately, the return is very nominal due to the high operating costs that are still being experienced with the present operation. The after tax DCF ROI is only about $1 \%$. In the future, as the operations are improved, one can expect a better ROI.

The rates of return for the NRU would have been considerably higher. Had the process been able to operate commercially, it would have generated an after tax $\mathrm{DCF}$ ROI of 35\%. If one were to add the capital and operating costs for the $\mathrm{CO}_{2}$ removal and dehydration processes, then the economic return for both of these options drop to a 22\% after tax ROI. That is still a very attractive return, especially for such an environmentally desirable project. 
EXHIBIT 38. Power Generation Capital Costs

\begin{tabular}{|c|c|c|c|c|}
\hline & $\underline{\text { Parts }}$ & Labor & $\begin{array}{l}\text { Taxes \& } \\
\text { Shipping }\end{array}$ & Totals \\
\hline Site Preparation & & & & $\$ 32,500$ \\
\hline Fencing & $\$ 6,700$ & & & \\
\hline Grounding Field & $\$ 10,000$ & & & \\
\hline Concrete Pad & $\$ 15,800$ & & & \\
\hline Electrical & & & & $\$ 79,610$ \\
\hline EACC Relays & $\$ 3,200$ & $\$ 1,200$ & & \\
\hline Substation & $\$ 34,500$ & & & \\
\hline Breakers & $\$ 21,170$ & $\$ 4,000$ & & \\
\hline Control Transformer & $\$ 860$ & $\$ 2,400$ & & \\
\hline Generator Control & $\$ 2,480$ & $\$ 4,000$ & & \\
\hline Control/Generator Wire & $\$ 5,800$ & & & \\
\hline Fuel Supply & & & & $\$ 144,405$ \\
\hline Gas Pipeline & $\$ 52,000$ & & & \\
\hline Pipeline ROW & $\$ 6,000$ & & & \\
\hline Gas Blower & $\$ 15,135$ & $\$ 3,500$ & & \\
\hline Gas Cooler & $\$ 20,000$ & $\$ 2,200$ & & \\
\hline Engine Fuel Lines & & $\$ 18,000$ & & \\
\hline Gas Regulators & $\$ 3,070$ & $\$ 4,500$ & & \\
\hline Shaft Air Ducting & $\$ 13,200$ & $\$ 6,800$ & & \\
\hline Engine/Generator Sets & & & & $\$ 335,630$ \\
\hline Engines & $\$ 74,200$ & & $\$ 5,400$ & \\
\hline Controls/Drivers & $\$ 36,615$ & & & \\
\hline Fabrication & & $\$ 86,400$ & & \\
\hline Oil Reservoirs & $\$ 1,440$ & $\$ 5,000$ & & \\
\hline Generators & $\$ 42,900$ & & & \\
\hline Generator Controls & $\$ 30,000$ & & & \\
\hline Capacitors & $\$ 7,200$ & & & \\
\hline Exhaust Piping & $\$ 4,550$ & $\$ 4,500$ & & \\
\hline Exhaust Blower & $\$ 13,525$ & & & \\
\hline Exhaust Stack & $\$ 19,400$ & $\$ 4,500$ & & \\
\hline General Shipping & & & $\$ 8,000$ & $\$ 12,000$ \\
\hline Taxes & & & $\$ 5,000$ & $\$ 6,000$ \\
\hline SUB-TOTALS & $\$ 439,745$ & $\$ 147,000$ & $\$ 18,400$ & $\$ 605,145$ \\
\hline \multicolumn{2}{|c|}{ Engineering \& Project Management } & & $15 \%$ & $\$ 90,772$ \\
\hline \multirow[t]{2}{*}{ Contingency } & & & $7 \%$ & $\$ 42,360$ \\
\hline & & \multicolumn{2}{|c|}{ TOTAL } & $\$ 738,277$ \\
\hline
\end{tabular}




\section{F. Permitting}

During the course of the project, several permits had to be obtained in order to carry out the project. The sections below describe those permits.

\section{Federal Energy Regulatory Commission (FERC)}

Independent power producers must receive certification for their installations from FERC. Small units such as the facility proposed for the Federal No. 2 Mine can go through a self-certification process under CFR 19 Sec. 292.203.207. NW Fuel accomplished this self-certification.

\section{Air Emissions Permits}

An application was submitted to the state of West Virginia, Department of Environmental Protection (DEP), Office of Air Quality for an air emission permit. The application for this project was originally submitted in July, 1997. A copy of the application is not provided in this Report due to its length. It consisted of 120 pages.

In 1998, the staff indicated the need for source tests on the engines. Since the project had not installed any equipment yet, it was fortunate that NW Fuel had identical engines in operation in Ohio. The state of West Virginia accepted tests on those engines for the purposes of the application.

Source tests were performed by Monarch Analytical Laboratories, Inc. on May 28, 1998. The results of these tests are presented in Appendix D. These tests indicated that some limitations would need to be specified in order to keep the total $\mathrm{NO}_{\mathrm{x}}$ emissions below $227 \mathrm{mt}$ (250 short tons) per year. If this limit were to be exceeded, then another type of permit would be required, to assure prevention of significant air quality deterioration. The proposal by NW Fuel was to limit the total electric energy produced in a given year to 9.1 million kwh. That would keep the total emissions of $\mathrm{NO}_{\mathrm{x}}$ below 227 mt per year. The other major criteria pollutant, CO, was not a problem. Its emissions were a fraction of $\mathrm{NO}_{\mathrm{x}}$ emissions.

After the May, 1998 emission tests, the WV DEP staff added another requirement. The projected emissions would have to be modeled using the EPA Screen3 modeling program. After several iterations, the DEP finally accepted NW Fuel's modeling results. The After operating the facility for three years, a Title V Permit Application was submitted to the WV DEP in August 2003. The Title V Permit was issued in september, 2004. The power generating units continue to operate under that Permit since that time.

It is evident that air emission permitting is a significant task in such a project. This is particularly onerous given the relatively small size of this facility.

\section{Gas Well Permits}

With the passage of legislation in 1994, the state of West Virginia now requires permitting of gob gas wells from which gas production is captured and utilized. The Oil and Gas Office in the state administers this permit process. The permitting of these gas wells was not as it would have been for a conventional gas well since the coal and gas owners in the Primary Area are not the same. NW Fuel had to obtain leases from the oil and gas owner for Vents \#22, \#29 and \#30. To complicate things further, the coal owner's (EACC) 
interests to coalbed methane (CBM) had been leased to CNG Producing Company (and subsequently assigned to DEPI). An agreement had to be negotiated with CNG in order to allow for CBM/CMM production from the gob wells. This was eventually accomplished. Then applications had to be made to file for CBM Well permits with the State of West Virginia. Those were issued for Vents 22 and 29.

\section{Land Ownership Review}

A preliminary land ownership review was performed for the Primary Area of Interest. This provided the basis for the oil and gas leasing mentioned above. There was also the need to review surface ownership so rights of way could be acquired for installation of pipelines. Fortunately, only two landowners had to give their permission for installation of the pipeline between Vents \#29 and the Parrish Shaft. Vent \#22 was also accessible from these same rights of way.

\section{CONCLUSIONS}

The Federal No. 2 Mine is a large mine with a history of innovative methane drainage techniques for improving mining safety and productivity. The Mine produces significant amounts of methane, providing a large potential for methane utilization. The characteristics of the coal encourage long consistent flows from ventilation wells, even after the active mining has been completed in an area. The current methane utilization project was a logical extension to past activities for methane capture and utilization at this Mine.

There were adequate gas resources in the Proposed Project Area to support an order of magnitude more electric power generation than the 1.2 MW project that was actually installed. There were some difficulties in accessing the available methane, but those were eventually overcome with the sealing of a part of the Mine and the subsequent production of gas from that sealed area.

The gas processing that had originally been envisioned could not be applied on a commercial basis. The gas quality form the gob holes had dropped to such a level that the CPSA process was not capable of producing a pipeline quality product. The process was demonstrated for a short period of time and then shut down.

The project would have been economically viable had the gas quality remained at previously tested levels. The use of a power generating system integrated with a gas processing system can still be viable at other coal mines. Such a system provides an unique opportunity to use both gob vent hole emissions as well as methane in ventilation fan exhaust as fuel for the generators. Incorporation of NW Fuel technology for nitrogen rejection provides the synergistic benefits of delivering pipeline quality gas and providing additional fuel for power generation.

The work in the various Phases of this project can provide the design for an integrated CMM utilization system for application at other coal mines. The techniques developed at this site will be immediately applicable to the many other mines operating in the Pittsburgh coalbed and readily adaptable to mines in other seams throughout America. 


\section{REFERENCES}

1. Cervik, J. A. Sainato, and M. Deul, "Water Infusion of Coalbeds for Methane and Dust Control", US Bureau of Mines Report of Investigations 8241, 27 p., 1977 .

2. Diamond, W. P., John C. LaScola, and D. M. Hyman, "Results of Direct-Method Determination of the Gas Content of U. S. Coalbeds", US Bureau of Mines Information Circular 9067, 95 p., 1986.

3. Diamond, W. P. and D. C. Oyler, "Directional Drilling for Degasification of Coalbeds in Advance of Mining", Maurice Deul, and Ann G. Kim, editors, Methane Control Research: Summary of Results 1964-1980, US Bureau of MinesB-687, 1988 .

4. Diamond, W. P., C. H. Elder, and P. W. Jeran, "Influence of Geology on Methane Emission from Coal", Maurice Deul, and Ann G. Kim, editors, Methane Control Research: Summary of Results 1964-1980, US Bureau of Mines-B-687, 1988 .

5. Diamond, W. P., A. T. Iannacchione, D. G. Puglia, and P. F. Steidl, "Geologic Studies of Gassy Coalbeds", Maurice Deul, and Ann G. Kim, editors, Methane Control Research: Summary of Results 1964-1980, US Bureau of Mines-B-687, 1988.

6. Diamond, W. P., M. C. Irani, G. N. Aul, and E. D. Thimons, "Instruments, Techniques, and Equipment", Maurice Deul, and Ann G. Kim, editors, Methane Control Research: Summary of Results 1964-1980, US Bureau of Mines-B-687, 1988 .

7. Erwin, Robert B., Director, "Spectrum of West Virginia Coal", West Virginia Geological and Economic Survey.

8. Fields, H. H., Steven Krickovic, Albert Sainato, and M. G. Zabetakis, "Degasification of Virgin Pittsburgh Coalbed Through a Large Borehole", US Bureau of Mines Report of Investigations 7800, 1973.

9. Fields, Herbert H., John H. Perry, and Maurice Deul, "Commercial-Quality Gas From a Multipurpose Borehole Located in the Pittsburgh Coalbed, " US Bureau of Mines Report of Investigation 8025, 14 p, 1975.

10. Fields, H. H., Joseph Cervik, and T.W. Goodman, "Degasification and Production of Natural Gas From an Air Shaft in the Pittsburgh Coalbed", US Bureau of Mines Report of Investigation 8173, 23 p, 1976.

11. Goodman, T. W., D. C. Oyler, and J. H. Perry, "Methane Drainage Through Shafts", Maurice Deul, and Kim, Ann G., editors, Methane Control Research; Summary of Results 1964-1980, Bureau of Mines-B-687, 1988.

12. Grau, R. H., III, and J. C. LaScola, "Methane Emissions from U.S. Coal Mines in 1980", US Bureau of Mines Information Circular 8987, 13 p., 1984.

13. Grau, Roy H., III, "An Overview of Methane Liberations from Us Coal Mines in the Last 15 Years", Third US Mine Ventilation Symposium, University Park, Pennsylvania, p. 251-255, October 12-14, 1987. 
14. Hunt, A. M. and Derak J. Steele, Coalbed Methane Technology Development in the Appalachian Basin, Topical Report, GRI Cont. \# 5089-214-1783, 1991.

15. Irani, M. C., E. D. Thimons, T. G. Bobick, M. Deul, and M. G. Zabetakis, "Methane Emissions from U.S. Coal Mines, A Survey", US Bureau of Mines Information Circular 8558, 58 p., 1972.

16. Irani, M. C., P. W. Jeran, and M. Deul, "Methane Emissions from U.S. Coal Mines in 1973, A Survey", US Bureau of Mines IC 8659, 47 p., 1974.

17. Irani, M. C., J. H. Jansky, P. W. Jeran, and G. L. Hassett, "Methane Emissions from U.S. Coal Mines in 1975, A Survey", USBM IC 8733, 55 p., 1977 .

18. Irani, M. C. and R. N. Kissell, "Methane Emissions in Underground Bituminous Coal Mines", Maurice Deul, and Kim, Ann G., editors, Methane Control Research: Summary of Results 1964-1980, USBM, B-687, 1988.

19. Kelafant, J. R., D. E. Wicks, and V. A. Kuuskraa, "A Geologic Assessment of Natural Gas from Coal Seams in the Northern Appalachian Coal Basin", GRI Topical Report (September 1986-September 1987), GRI Report 88/0039, 86 p., March, 1988 .

20. Kim, Ann, "Methane Drainage from Coalbeds; Research and Utilization", Methane Gas from Coalbeds-Development Production and Utilization, MERC/SP$78 / 1, \mathrm{p} .12-17,1971$.

21. Kim, Ann G. and F. N. Kissell, "Methane Formation and Migration in Coalbeds", Maurice Deul, and Ann G. Kim, editors, Methane Control Research: Summary of Results 1964-1980, Bureau of Mines-B-687, 1988.

22. Kim, A. G. and M. Deul, "Conservation of Methane Drained From Coal", Maurice Deul, and Ann G. Kim, editors, Methane Control Research: Summary of Results 1964-1980, Bureau of Mines-B-687, 1988.

23. Kissell, Fred, "The Methane Migration and Storage Characteristics of the Pittsburgh, Pocahontas No. 3, and Oklahoma Hartshorne Coalbeds", US Bureau of Mines Report of Investigation 7667, 1972.

24. Kissell, F. N., "The Direct Method of Determining Methane Content of Coalbeds for Ventilation Design", US Bureau of Mines Report of Investigations $7767,17 \mathrm{p} ., 1973$.

25. Sööt, Peet M., "Horizontal Well Coalbed Methane Production Relative to Face Cleat Orientation", Proceedings of the 1989 Coalbed Methane Symposium, The University of Alabama/Tuscaloosa, 1989.

26. Sööt, Peet M., "Survey of U.S. Coal Mine Degasification Processes", Report under EPA Contract number 68-D9-0173, 20 p., October 3, 1990.

27. Trevits, M. A., S. W. Lambert, P. F. Steidl, and C. H. Elder, "Methane Drainage Through Small Diameter Vertical Boreholes", Maurice Deul, and Kim, Ann G., editors, Methane Control Research: Summary of Results 19641980, US Bureau of Mines-B-687, 1988.

28. TRW Energy Systems Group, Methane Produced from Coalbeds: Systems Studies of Energy Conservation, MERC/CR-77/4, 2 Vol., 1977. 
29. Ulery, J. P. and G. M. Molinda, "Influence of Overlying Strata on Methane Emissions in a Northern West Virginia Coal Mine", US Bureau of Mines Report of Investigation $8879,14 \mathrm{p}, 1984$.

30. Zabetakis, M. G., T. D. Moore, Jr., A. E. Nagel, and J. E. Carpetta, "Methane Emission in Coal Mines: Effects of Oil and Gas Wells", US Bureau of Mines Report of Investigation 7658, 9 p., 1972. 
VI. LIST OF ACRONYMS AND ABBREVIATIONS

$\begin{array}{ll}\text { Cfm } & \text { cubic feet per minute } \\ \text { CNGP } & \text { Consolidated Natural Gas Producing Company } \\ \text { CPSA } & \text { continuous pressure swing adsorption } \\ \text { DEPI } & \text { Dominion Exploration \& Production Inc. } \\ \text { EACC } & \text { Eastern Associated Coal Corporation } \\ \text { IC } & \text { internal combustion (engine) } \\ \text { MCF } & \text { thousand cubic feet } \\ \text { MCFD } & \text { thousand cubic feet per day } \\ \text { MMCF } & \text { million cubic feet } \\ \text { MMCFD } & \text { million cubic feet per day } \\ \text { MMmtpy } & \text { million metric tons per year } \\ \text { MMTPY } & \text { million short tons per year } \\ \text { MRE } & \text { metric ton } \\ & \text { short ton }\end{array}$


APPENDIX A

PITTSBURGH COAL SEAM GEOLOGY 
I. West Virginia Coal Information

West Virginia contains 117 named coal seams which underlay 75\% of the State with original reserves estimated to be 117 billion tons (Erwin) . Estimates of remaining minable reserves from the 62 minable seams in West Virginia 57 billion tons (Exhibit A1). Fourteen percent (127 million tons) of the national coal production came from West Virginia in 1985 with 21\% of this generated from the Pittsburgh Coalbed. Over 10 million tons of coal was mined in Monongalia county alone.

Western Monongalia County has minable reserves of the Washington, Waynesburg, Sewickley, and Pittsburgh Coalbeds (Ulery and Molinda) with reserves of the Pittsburgh seam for Monongalia County estimated to be over 1.3 billion short tons (Hunt and Steele).

Average analyses from West Virginia Coal by County is shown in Exhibit A2 and general information about the Northern Appalachian Basin coals and their gas characteristics is given in Exhibit A3 (Hunt and Steele).

II. Pittsburgh Coal Characteristics

The Pittsburgh bed has a uniform character over 6,000 square miles in WV, Pennsylvania, Ohio and Maryland with a thickness of 8-14 feet thick in Northern WV (Exhibit A4, TRW). It is one of the largest and most valuable coalbeds in the world (Diamond, et al, 1988). It is found at a depth of 800-1,200 feet in western Monongalia County yet outcrops along the Monongahela River and in eastern Monongalia County (Exhibit A5, TRW). It is rated as a High-Volatile A Bituminous Coal. The Federal No. 2 Mine is located in an area containing coal with 12,000-13,500 Btu/CF, greater than 12\% Ash, and 2-3\% sulfur (Erwin).

Exhibit A6 lists specific coal characteristics for the Pittsburgh seam in WV (Erwin).

III. Stratigraphy

A diagram of Pennsylvanian Geologic Strata is shown in Exhibit A7, with more detail regarding the coalbeds at the Federal No. 2 Mine given in Exhibit A8 (Diamond, et al, 1988, and TRW). A corehole record from the MPB site reveals the exact thickness and position of the coalbeds down to the Pittsburgh Seam at this position in the Federal No. 2 Mine (Exhibit A9, Fields, et al, 1973).

The minable coalbeds in this region belong to the Pennsylvanian system and were deposited 280-310 million years ago. The Pittsburgh Coalbed is the basal unit of the Monongahela Group deposited during the late Pennsylvanian. The Monongahela Group contains the Pittsburgh, Redstone, Sewickley, and Uniontown Coalbeds and is divided into the Pittsburgh and Uniontown Formations. The Pittsburgh Formation is further divided into five members, Lower, Redstone, Fishpot, Sewickley, and Upper, and is 275 to $350^{\prime}$ thick in and near the Federal No. 2 Mine (Ulery and Molinda). ${ }^{1}$

\footnotetext{
${ }^{1}$ see reference in the main body of the report, pp. 75-77
} 
EXHIBIT A1. West Virginia Coal Reserves (millions of tons)

WEST VIRGINIA COA! RESERVE BASE $\{1,000,000$ tOns

\begin{tabular}{|c|c|}
\hline TOTAL & REMAPRS \\
\hline 178,700 & 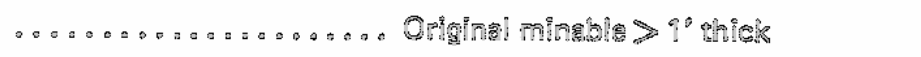 \\
\hline 8.9, 06 & 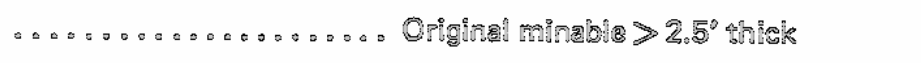 \\
\hline 18,832 & $000 \ldots \ldots \ldots \ldots \ldots$ Mined out and loss gince 1883 \\
\hline 72,232 & 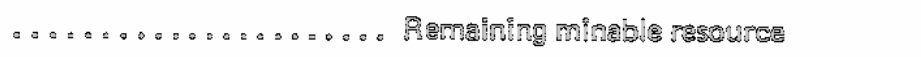 \\
\hline 37786 & 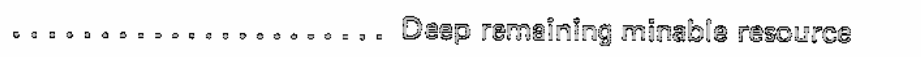 \\
\hline 94,696 & \# \\
\hline 39.782 & 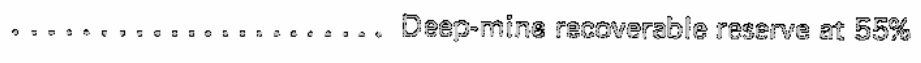 \\
\hline 46,228 & …… \\
\hline
\end{tabular}


EXHIBIT A2. Average Coal Analyses by County and Bed

\begin{tabular}{|c|c|c|c|c|c|c|c|c|c|c|c|}
\hline \multicolumn{12}{|l|}{ WEST VIRGINIA } \\
\hline COUNTY & BED & A.R. & \multicolumn{2}{|c|}{$\begin{array}{l}\text { ASH } \\
\text { A.R. DRY }\end{array}$} & \multicolumn{3}{|c|}{ A.R. SULFUR } & \multicolumn{2}{|r|}{$\begin{array}{l}\text { BTU } \\
\text { DRY }\end{array}$} & \multirow{2}{*}{$\begin{array}{l}\text { M\&AF } \\
15,220\end{array}$} & \multirow{2}{*}{$\begin{array}{c}\text { NO. OF } \\
\text { ANAL } \\
361\end{array}$} \\
\hline BARBOUR & 036 & 2.1 & 9.9 & 10.2 & 3.1 & 3.2 & 3.5 & 13,380 & 13,670 & & \\
\hline BRAXTON & 036 & 2.6 & 8.1 & 8.4 & 2.3 & 2.4 & 2.6 & 13.190 & 13,540 & 14.780 & 25 \\
\hline BRDOKE & 2036 & 8.2 & 19.5 & 12.3 & 23 & 2.5 & 2.8 & 11,985 & 12,830 & 14,510 & 45 \\
\hline BALHOUM & DSB & 3.2 & 6.8 & 7.0 & 3.3 & 3.4 & 3.5 & 13.780 & $1 \overline{3,830}$ & 14,650 & 2 \\
\hline  & the & 2.5 & 8.2 & 2.3 & 2.2 & 2.3 & 2.5 & 12,030 & 13,500 & $14,8 \times 0$ & 108 \\
\hline 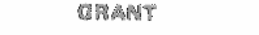 & $\infty$ & .5 & 5.3 & 5.4 & $s$ & 1.0 & 1.8 & 13.760 & 14,950 & $1 E_{0} .740$ & 11 \\
\hline HANGO6K & 038 & 3.4 & 兽. 9 & 3. & 3.5 & 3.3 & 3.6 & 12,760 & 03.230 & 14,440 & 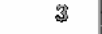 \\
\hline MARIAISON & ass & 2.3 & 8.5 & 淃 & 3.0 & 3.5 & 3.3 & 13.478 & 13.790 & 15,100 & 2459 \\
\hline KANAWWA & 038 & 2.5 & 5.2 & (3.4) & 3.8 & 9.8 & 2.0 & 13,520 & 13.870 & 14,930; & $1 \%$ \\
\hline LEG & $\cos 5$ & 3.1 & sas & 8.8 & 3.0 & 3.2 & 3.5 & 93.050 & 13.498 & 14,830 & (פ) \\
\hline MAMION & $a 3$ & 2.2 & 7.5 & 8.0 & 8.8 & 1.7 & 1.25 & 13.630 & 13.240 & 93.990 & 40 \\
\hline MARSAMLL & 93 & 2.0 & 8.8 & 8.8 & 4.3 & 4.5 & 4.8 & 13.220 & 13,630 & 94,820 & 42 \\
\hline RASON & 038 & 8.5 & 12,4 & १3.3 & 3.8 & 3.0 & 3.4 & ง1.500 & จ2.390 & 14,300 & 70 \\
\hline POUNERARL & 036 & 2.1 & . & 7.0 & .8 & 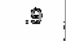 & $\$$ & 13,880 & 14,190 & 15.968 & 8 \\
\hline MONONGARBA & 936 & 2.2 & 8.3 & 5.8 & 2.7 & 2.8 & 3.0 & 13,460 & 13,760 & 15,220 & 8862 \\
\hline oHto & 203 & 3.2 & 9.31 & 3.7 & 3.6 & 2.2 & 4.2 & 12,920 & 13,250 & 14.790 & 31 \\
\hline PMESTON & 636 & 4.2 & 7.6 & 敋. & 1.3 & 1.3 & 1.4 & 13.010 & 03,.600 & 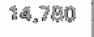 & 7 \\
\hline PUTNASA & 098 & 3.8 & 9.2 & 9.8 & 2.8 & 3.0 & 3.3 & 12,650 & 13,180 & $1 a_{a} 680$ & 43 \\
\hline ROANE & 008 & 9.8 & 6.8 & (6.2: & $1, \frac{3}{8}$ & 20 & 2.8 & 13.563 & $93,7: 0$ & $: 4.723$ & 4 \\
\hline $74 \%(10 \%$ & $2 x^{2}$ & $2 ?$ & S.2. & (2. 6 & 27 & 23 & 2.4 & 12,980 & 13970 & 施, & $2 \sqrt{2}$ \\
\hline 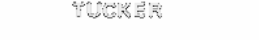 & 65 & . & ธ్. & 5 & 5 & 9.8 & 5.8 & 0, age & 85030 & : & 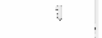 \\
\hline GPand & ats & $2 . \overline{2}$ & S: & S.? & 32 & 3.6 & 3.2 & 53,600 & T. & 83,909 & 78 \\
\hline 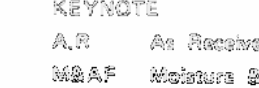 & ! & & & & & & & & & & \\
\hline
\end{tabular}


Exhibit A3. Comparative Reservoir and Geologic Characteristics of the Appalachian and Warrior Basins

\begin{tabular}{|c|c|c|c|}
\hline $\begin{array}{l}\text { Reservoir and Geologic } \\
\text { Characteristics }\end{array}$ & $\begin{array}{l}\text { Appalachian } \\
\text { Nortbern }\end{array}$ & $\begin{array}{l}\text { Basin } \\
\text { Central }\end{array}$ & Black Warrior Basin \\
\hline Gas content (Scf/ton) & $\begin{array}{l}100 \cdot 440 \\
\text { (Lower) }\end{array}$ & $\begin{array}{l}205-660 \\
\text { (Similar) }\end{array}$ & $\begin{array}{l}300-500 \\
\text { (Productive Basin) }\end{array}$ \\
\hline Permeability (md.) & $\begin{array}{l}0.1-26 \\
\text { (Lower) }\end{array}$ & $\begin{array}{l}5-27 \\
\text { (Similar) }\end{array}$ & $\begin{array}{c}2-30 \\
\text { (Productive Basin) }\end{array}$ \\
\hline Sorption time ( \pm days) & $\begin{array}{l}60-600 \\
\text { (Slower) }\end{array}$ & $\begin{array}{l}1-3 \text { days } \\
\text { (Similar) }\end{array}$ & $\begin{array}{l}3-5 \text { days } \\
\text { (Productive Basin) }\end{array}$ \\
\hline Coal rank (bituminous) & High Vol & Low - Med Vol & Med - High Vol \\
\hline Gas in place $(\mathrm{Tcf})$ & 61 & 5 & 20 \\
\hline Stratigraphic position & Above Pousville & Pottsville & Pottsville \\
\hline Target depth (feet) & $800-1,200$ & $1,500-2,500$ & $450-4,000$ \\
\hline Hydrostatic gradient (psi/foot) & $0.18-0.30$ & $0.35-0.43$ & $0.35-0.43$ \\
\hline \multicolumn{4}{|l|}{$\begin{array}{l}\text { Historical Technological } \\
\text { Approach }\end{array}$} \\
\hline Fracture treatment size & $\begin{array}{c}\text { Smaller } \\
\text { Not state-of-the-art }\end{array}$ & $\begin{array}{l}\text { Smaller } \\
\text { Not state-of-the-art }\end{array}$ & State-of-the-art \\
\hline $\begin{array}{l}\text { Completion and production } \\
\text { technology }\end{array}$ & Not state-of-the-art & Not state-of-the-art & State-of-the-art \\
\hline
\end{tabular}




\section{Exhibit A4. Pittsburgh Coalbed Seam Thickness Isopach Map}

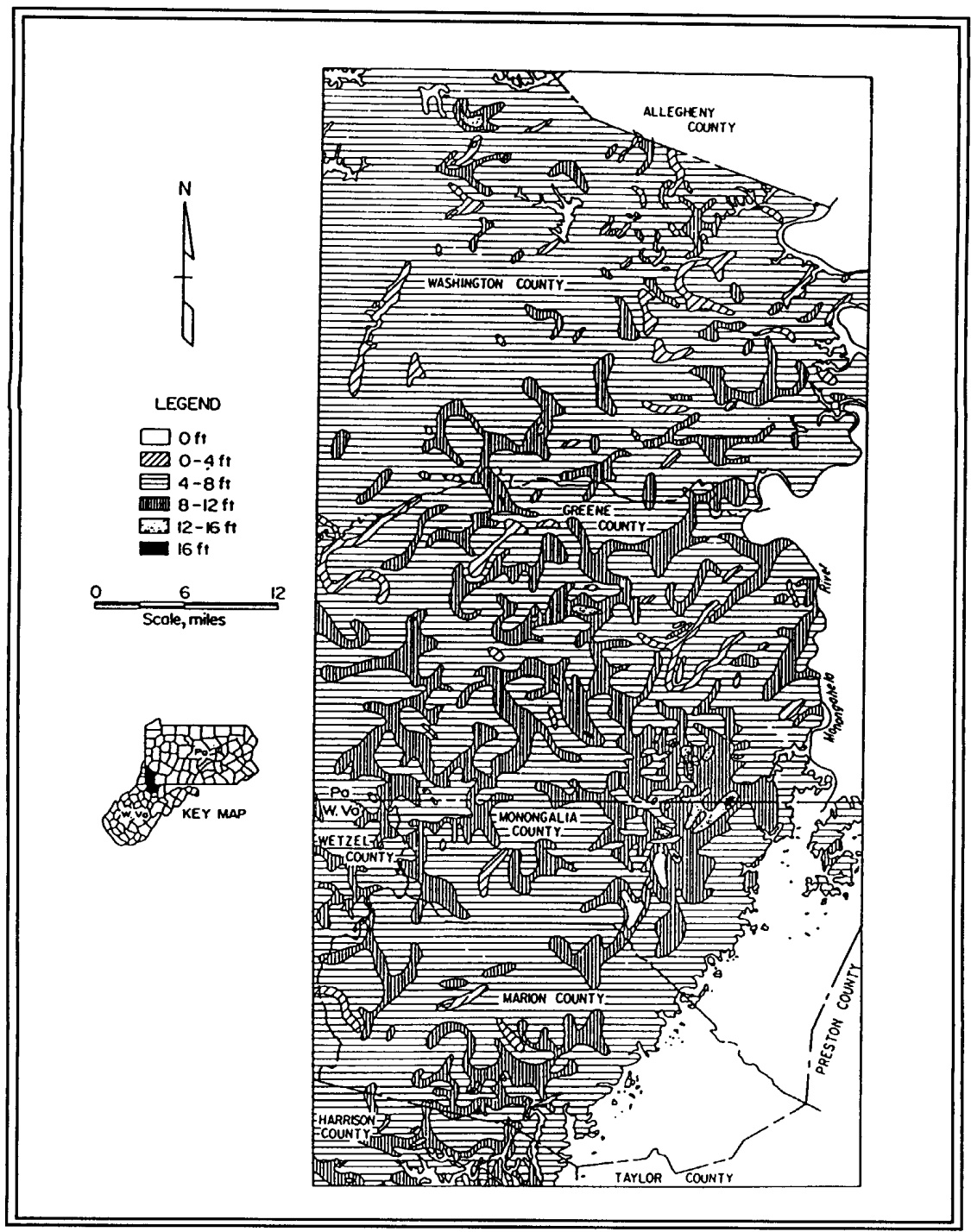


Exhibit A5. Pittsburgh Coalbed Overburden Isopach Map




Exhibit A6.

\begin{tabular}{lcc}
\multicolumn{3}{c}{ Coal Characteristics of the Pittsburgh Seam in WV } \\
& Average & Range \\
Heating Value (Btu/CF) & 13,200 & $12,100-14,100$ \\
Ash Content (\%) & 6.7 & $4-15$ \\
Moisture Content (wt \%) & 1.3 & $0.5-4$ \\
Volatile Matter (\%) & 38 & $26-42$ \\
Fixed Carbon (\%) & 53 & $46-60$ \\
Chlorine Content (\%) & 0.04 & $0.007-0.107$ \\
Sulfur content (\%) & 2.4 & $1-4.4$ \\
\hline
\end{tabular}


Exhibit 7. Strata of Pennsylvanian-age Coalfields in the Appalachian Basin

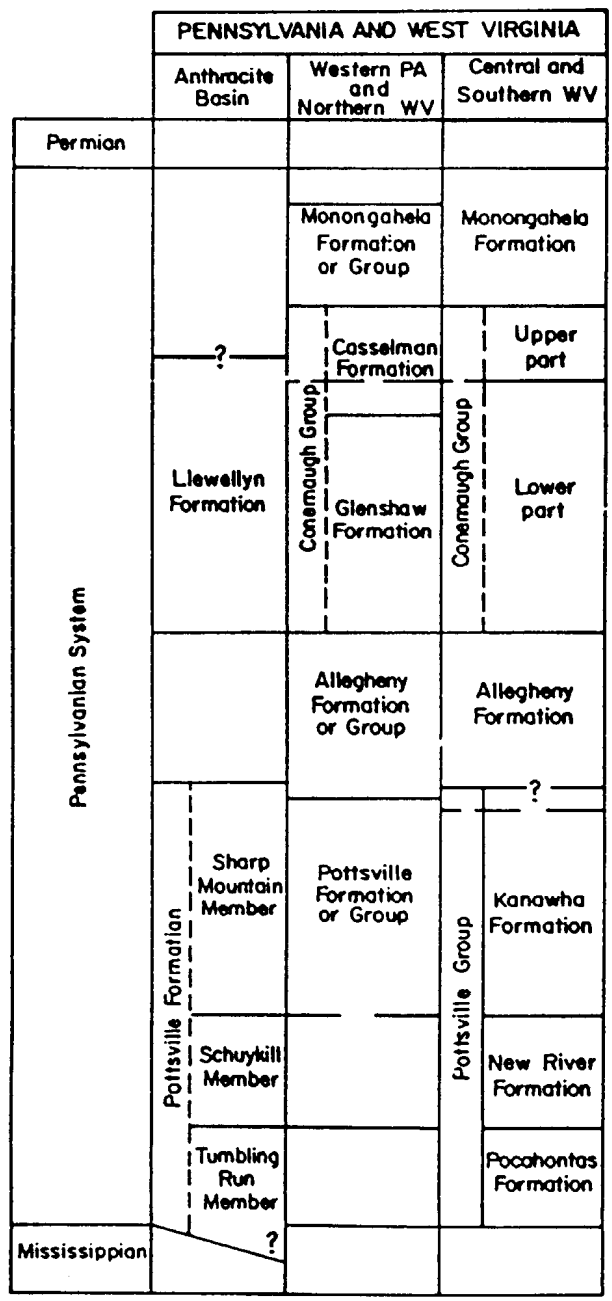


Exhibit A8. Stratigraphic Column for Pennsylvanian-age Coals

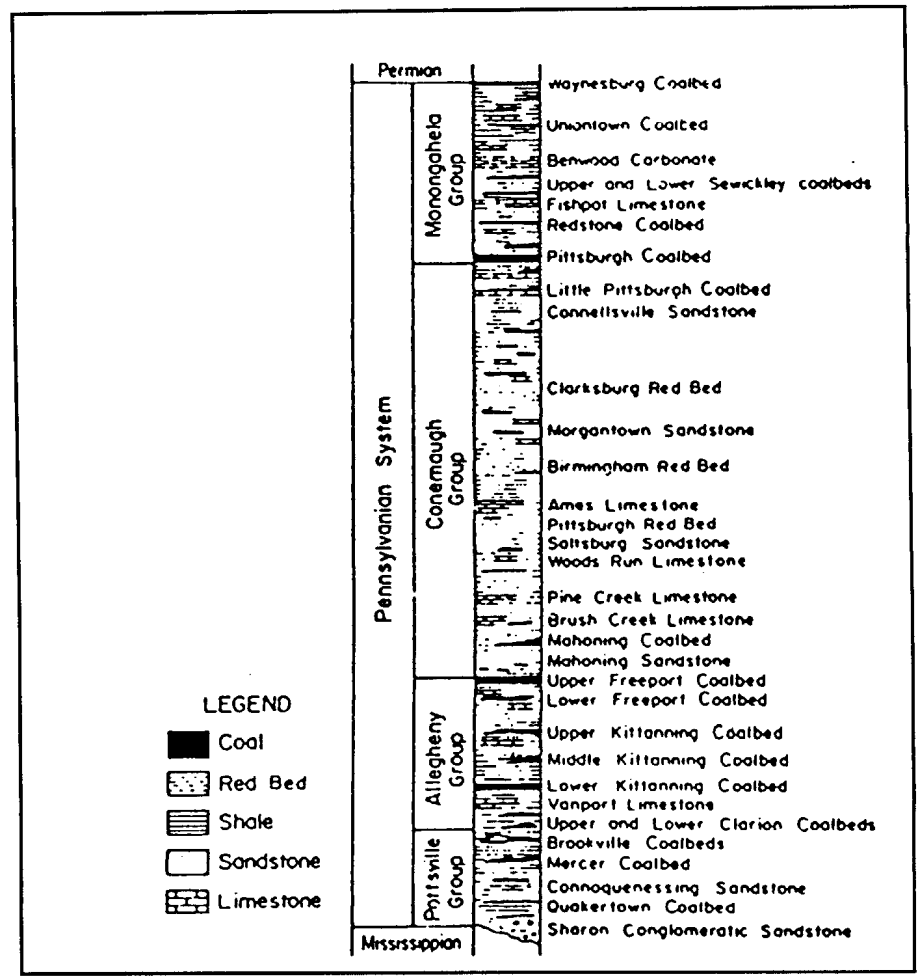


Exhibit A9. MPB Corehole Logs

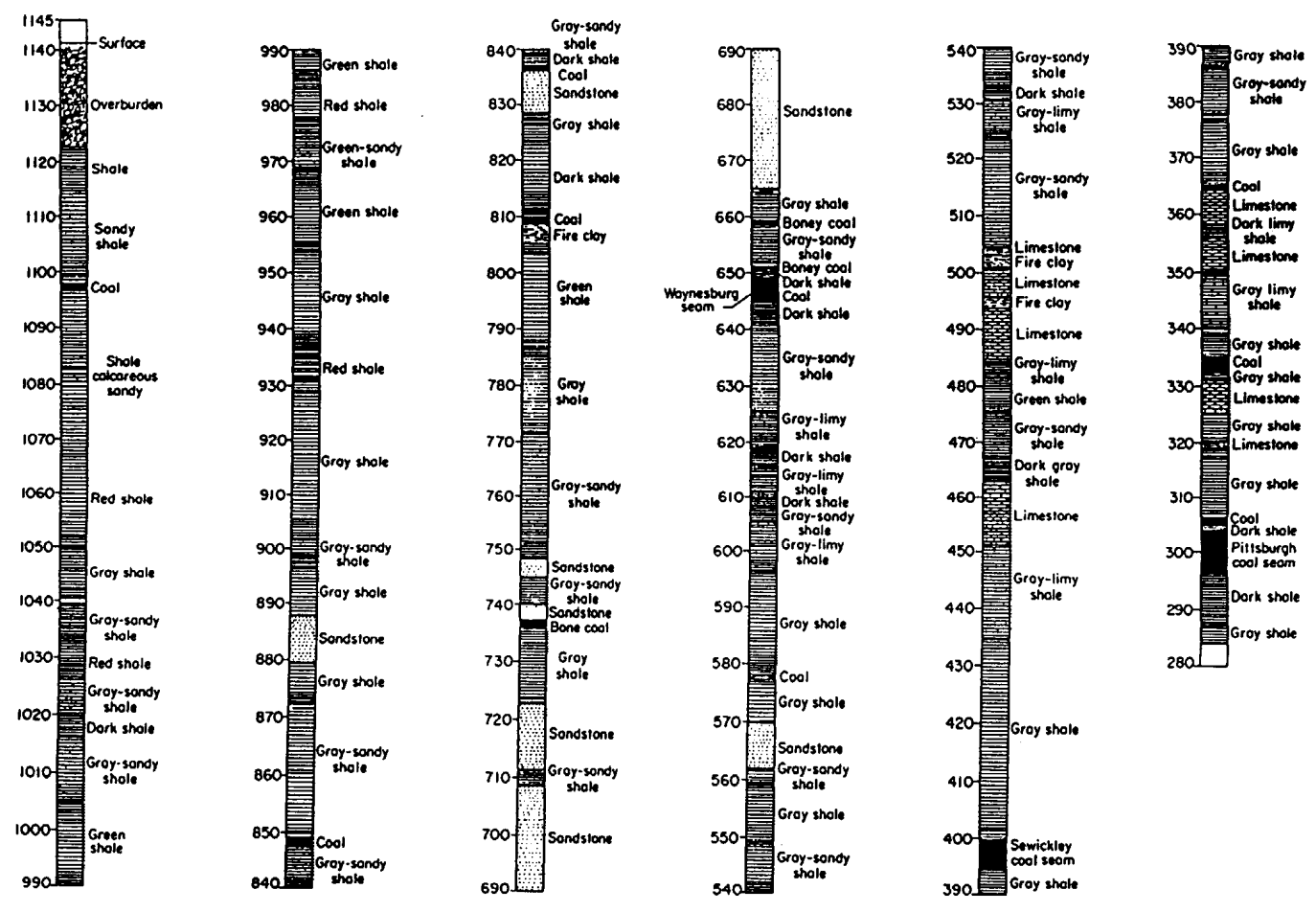


The lower member is 25-45' thick (Exhibit A10, Ulery and Molinda). Its base is the Pittsburgh coalbed which is covered by 1.5 to 8 ' thick sequence of various shales interbedded with up to 5 impure and bony coalbeds which range in thickness from 2 to 29 inches. The thickness of the Pittsburgh Coalbed at the Federal No. 2 Mine has been listed in various sources as 84-103 (Ulery and Molinda), 6.5 to 7.5 feet (TRW), and 9 feet, with 7 feet currently being mined (Zabetakis). During the more recent high production years the depth has been most frequently reported at 96". Above this is a medium to dark gray limey shale which grades into gray shaly limestone and fine-grained non-marine limestone; portions of this also contain fine-grained sandstone and sandy shale.

The Redstone Member ranges from 25-35 feet in thickness and includes the Redstone Coalbed which is 0-22 inches thick. Overlying this coalbed is a soft clay shale, limestone, and calcareous shale.

The Fishpot Member is 20-30' thick with the Fishpot coalbed ranging from 0-12 inches overlain with gray or clay shales. Above the shale is a coarse clastic sequence of gray sandy shale and minor fine-grained sandstone 3 to 25 feet thick which is covered by 1-4 feet of clay or carbonaceous shale that is directly under the Sewickley coalbed.

The Sewickley Coalbed is 3-5 feet thick and overlain with up to 50 feet of sandstone.

The Uniontown, Waynesburg and Washington coalbeds lie above this with thicknesses of $1-3,3-5$, and 2-5 feet respectively.

The Upper Freeport Coalbed lies 600 feet below the Pittsburgh seam and the Lower Kittanning is 275 feet further down at the Federal No. 2 Mine. These seams range from 0-6 feet and 3-8 feet in thickness (TRW).

IV. Structure

The Federal No. 2 Mine is on the Pittsburgh Plateau section of the Appalachian Plateau which consists of broad open folds trending NE-SW with little faulting. It is just southwest of the terminations of the Belle Vernon anticline and the Whitely syncline and is located midway between the axes of the Mooresville anticline and the Waynesburg syncline (Ulery and Molinda). Exhibit All shows the regional structure (TRW).

The Pittsburgh coal seam is classified as "blocky", with a well developed cleat system composed of the dominant fractures forming the face cleat, and minor fractures at right angle to this forming the butt cleat. The local face cleat orientation at the Federal No. 2 Mine is N 170 E (Diamond, et al, 1988).

\section{Coalbed Pressure}

Cervik has reported an in situ pressure of 275 psig in the Pittsburgh seam with others estimating 260 psig for this bed (TRW). At the Federal No. 2 Mine the in situ pressure was recorded to be 203 psig at the MPB (Fields, et al, 1973) and $278 \mathrm{psig}$ at a site used to test vertical boreholes (Trevits, et al). 


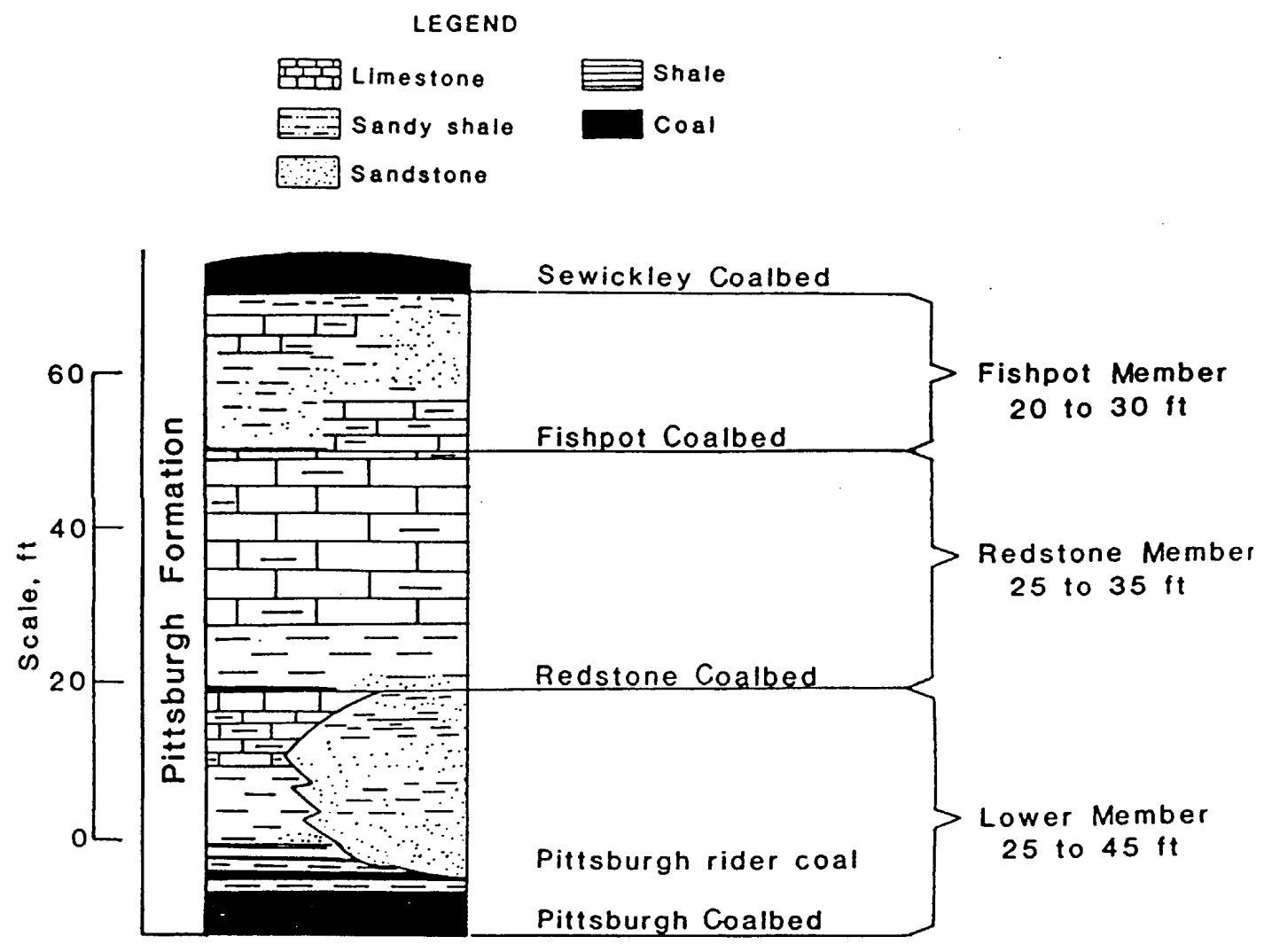




\section{Exhibit A11. Pittsburgh Coalbed Regional Structure Map}

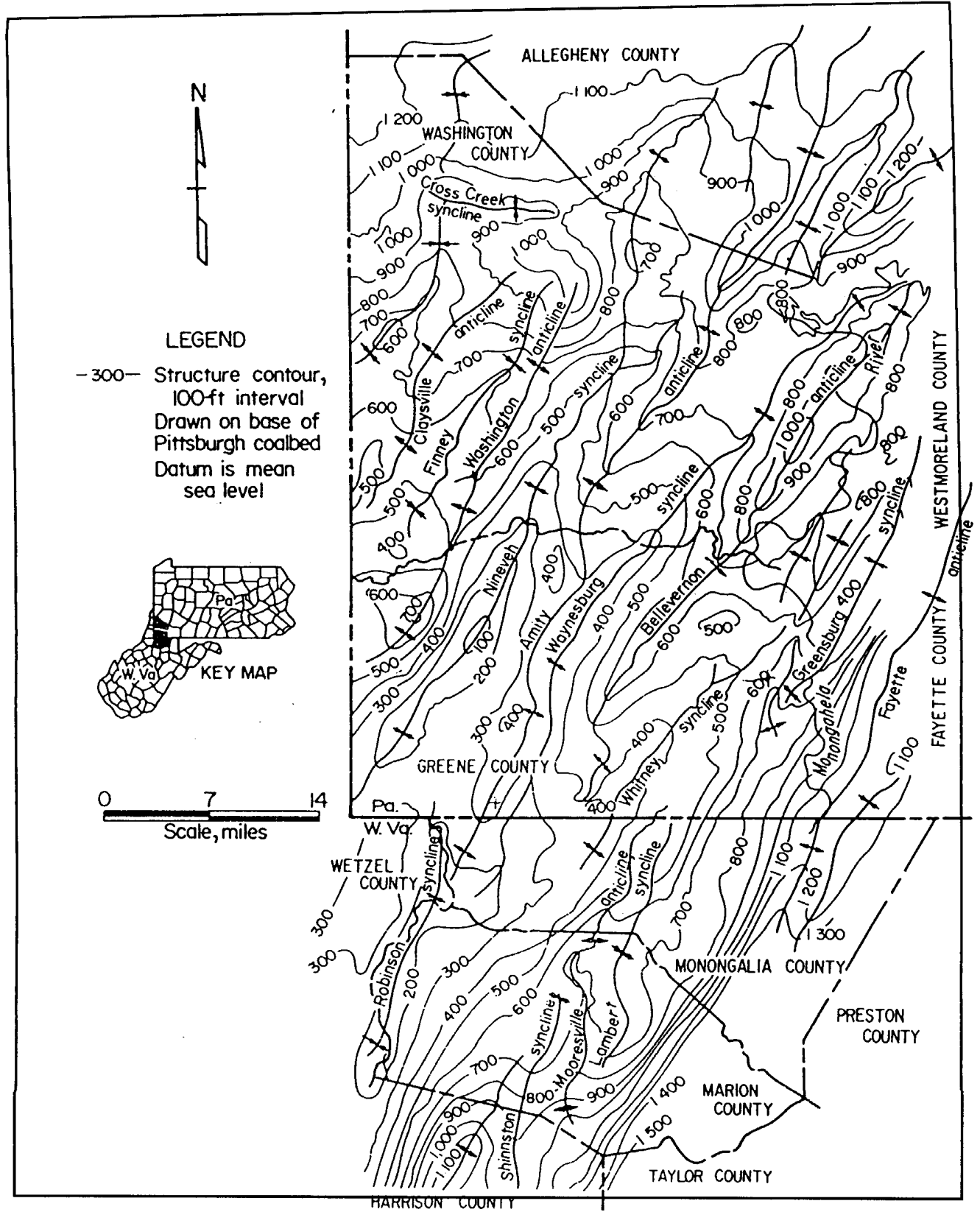


VI. Permeability

The permeability of the Pittsburgh coal seam was calculated by Kissell from pressure and flow measurements in horizontal boreholes. Pressure curves as a function of hole length were prepared and the permeability was calculated by fitting this curve to the Darcy equation with the following assumptions:

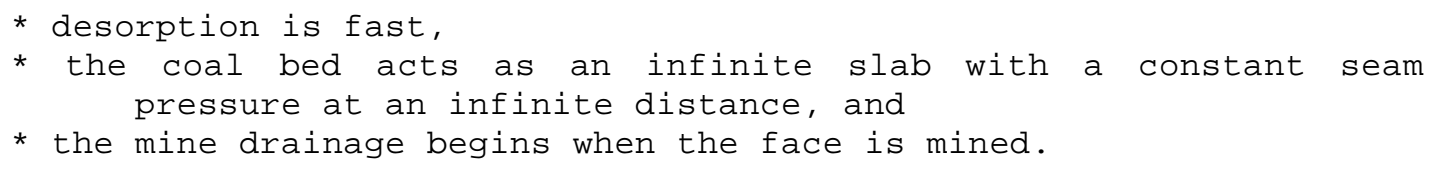

It was found that the permeability varied widely even within a given seam. The permeability estimates were between 0.7 to 181 md for the Pittsburgh Coalbed. Other estimates for coal in this region have ranged from $0.1-26$ md (Exhibit A3, Hunt and steele). The permeabilities were much higher in holes which crossed the face cleats at right angles. Crush zones, regions of very high permeability, 1.6 to 20 feet in length were seen at the mining face. These are presumably caused by the pressure exerted once the mined coal has been removed.

Permeability increased markedly with time but the reason for this is unclear. Inaccurate assumptions may contribute to the apparent increase but the author does not feel that these can account for all of the increase. Other factors may be the removal of water from the seam with mining and ventilation and a possible opening of cracks due to the desorption itself (coal has been found to expand as much as $0.1 \%$ under 40 atm of methane).

The actual values are suspect and of limited use. The Pittsburgh data may be especially inaccurate as this coal is known to be "blocky" in nature with a well developed cleat structure at 6" intervals (TRW). It has a low diffusion coefficient and a high permeability (Kim and Kissell), which is the opposite of the analytical premise. The fracture permeability also allows the coalbed to begin draining well ahead of the face. Also, the coalbed pressure was estimated at 120 psig whereas the typical estimate is 275 psig, a difference which would likely cause an overestimation of permeability.

It is important to note that permeabilities are highly variable, will depend upon the face direction in coals with highly developed cleat structures, will decrease with moisture, and tend to dramatically increase with time and allow much higher flow rates over longer periods of time than would be predicted by a constant permeability assumption. The Pittsburgh seam was clearly more permeable and contained more directional anisotropy than the other coals tested. No dependence on overburden was found.

The in situ diffusion characteristic (D/a2), was determined by laboratory pressure testing to be $1.6 \mathrm{X} 108$, and measured from a borehole at $2.9 \mathrm{X} 108$ (Kim and Kissell). 
APPENDIX B

GOB VENT BLOWER TESTS - 1998 


\section{Appendix B: 1998 Blower Tests on Vents 29 and 30}

The blower tests performed on Vents 29 and 30 took place during the summer of 1998. A Tuthill Blower driven by a 50 horsepower engine was used for these tests. The blower was taken to the site on July 21. It was installed on Vent 29. After a brief shakedown period, the blower was shut down for the night. The extended flow test of Vent 29 began on July 22. The blower was operated continuously for over five days. The results are presented in Exhibit B-1. The blower maximum capacity was limited due to the discharge temperature of the gas. If the engine was driven too hard, it raised the gas temperature to a point at which it would damage the blower. The test was terminated after the blower had automatically shut itself off due to high discharge temperature at 1 am on July 28 .

The test on Vent 29 was successful. The Vent was shown to be capable of producing over $4 \mathrm{~m}^{3} / \mathrm{min}$ (200 MCFD) of gas containing 90\%+ methane. That single Vent can provide half the fuel supply for the generators.

After the conclusion of the blower test on Vent 29, the equipment was moved to Vent 30. The test on this Vent was run for about 20 hours. The results are also provided in Exhibit B-1.

Vent 30 was found to be even more productive than Vent 29. It was capable of producing more than twice the gas flow. At one point it delivered over 10 $\mathrm{m}^{3} / \mathrm{min}$ (500 MCFD). The methane concentration was lower, at 80\% to 85\%. In total, it is still more than twice the methane flow from Vent 29.

During the flow test on Vent 30, the wellhead pressure was measured at Vent 29. It showed a lower pressure than was experienced when the blower was not in operation. This may indicate some underground communication between these Vents. This is understandable due to the amount of fracturing which takes place during the longwall mining. This will have to be monitored during the commercial production of gas, so the reservoir is produced properly.

In each blower test, the pressure in the reservoir came back to undisturbed levels very rapidly after the blower was shut off. It took about one minute for Vent 29 to return to ambient pressure after the blower was shut off. This implies that the wellbore reservoir is of limited size, but it can be readily recharged from the surrounding strata.

These two Vents will be capable of providing the total fuel supply necessary for the power generating units to be installed at the Federal No. 2 Mine. 
Exhibit B-1. Federal No. 2 Mine Vent Tests

July, 1998

Vent 29

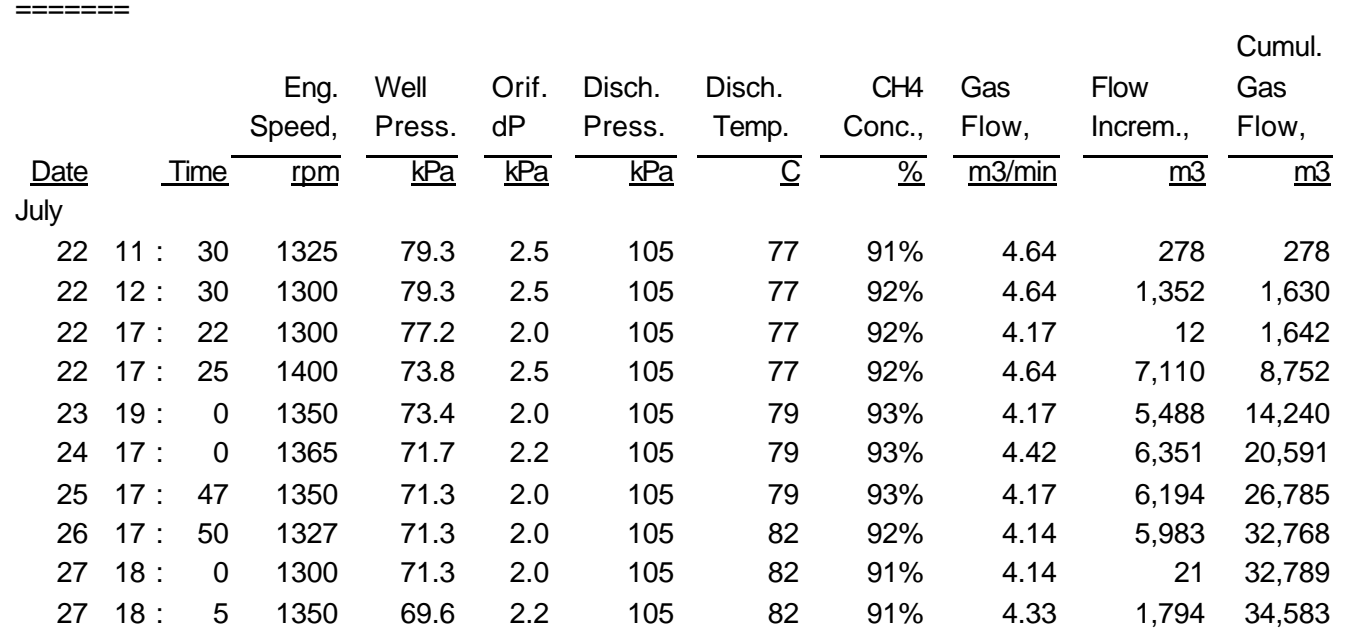

Vent 30

\begin{tabular}{|c|c|c|c|c|c|c|c|c|c|c|c|}
\hline Date & & $\underline{\text { Time }}$ & $\begin{array}{r}\begin{array}{r}\text { Eng. } \\
\text { Speed }\end{array} \\
\underline{\text { Rpm }}\end{array}$ & $\begin{array}{l}\text { Well } \\
\text { Press. } \\
\frac{\mathrm{kPa}}{\underline{ }}\end{array}$ & $\begin{array}{l}\text { Orif. } \\
\mathrm{dP} \\
\underline{\mathrm{kPa}}\end{array}$ & $\begin{array}{l}\text { Disch. } \\
\text { Press. } \\
\underline{\mathrm{kPa}}\end{array}$ & $\begin{array}{l}\text { Disch. } \\
\text { Temp. } \\
\underline{\mathrm{C}}\end{array}$ & $\begin{array}{r}\begin{array}{r}\mathrm{CH} 4 \\
\text { Conc., }\end{array} \\
\underline{\%}\end{array}$ & $\begin{array}{l}\text { Gas } \\
\text { Flow, } \\
\underline{\mathrm{m} 3 / \mathrm{min}}\end{array}$ & $\begin{array}{l}\begin{array}{l}\text { Flow } \\
\text { Increm., }\end{array} \\
\underline{\mathrm{m} 3}\end{array}$ & $\begin{array}{l}\text { Cumul. } \\
\text { Gas } \\
\text { Flow, } \\
\underline{\mathrm{m} 3}\end{array}$ \\
\hline \multicolumn{12}{|l|}{ July } \\
\hline 29 & 14 & 50 & 1650 & 79.3 & 7.5 & 105 & 63 & $77 \%$ & 7.6 & 1,028 & 1,028 \\
\hline 29 & 17 & 5 & 1650 & 79.3 & 7.5 & 105 & 63 & $80 \%$ & 7.6 & 7,043 & 8,070 \\
\hline 30 & 8 & 30 & 1725 & 78.5 & 7.5 & 105 & 63 & $85 \%$ & 7.6 & 228 & 8,299 \\
\hline 30 & 9 & 0 & 2600 & 74.2 & 15 & 108 & 88 & $85 \%$ & 10.3 & 154 & 8,453 \\
\hline 30 & 9 & 15 & 2425 & 74.7 & 13 & 105 & 93 & $82 \%$ & 9.5 & 711 & 9,164 \\
\hline 30 & 10 & 30 & 2440 & 73.4 & 13 & 105 & 96 & $83 \%$ & 9.5 & 66 & 9,230 \\
\hline 30 & 10 & 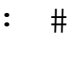 & Lowe & & & & & & & & \\
\hline
\end{tabular}


APPENDIX C

POWER GENERATION CAPITAL COST DETAIL 


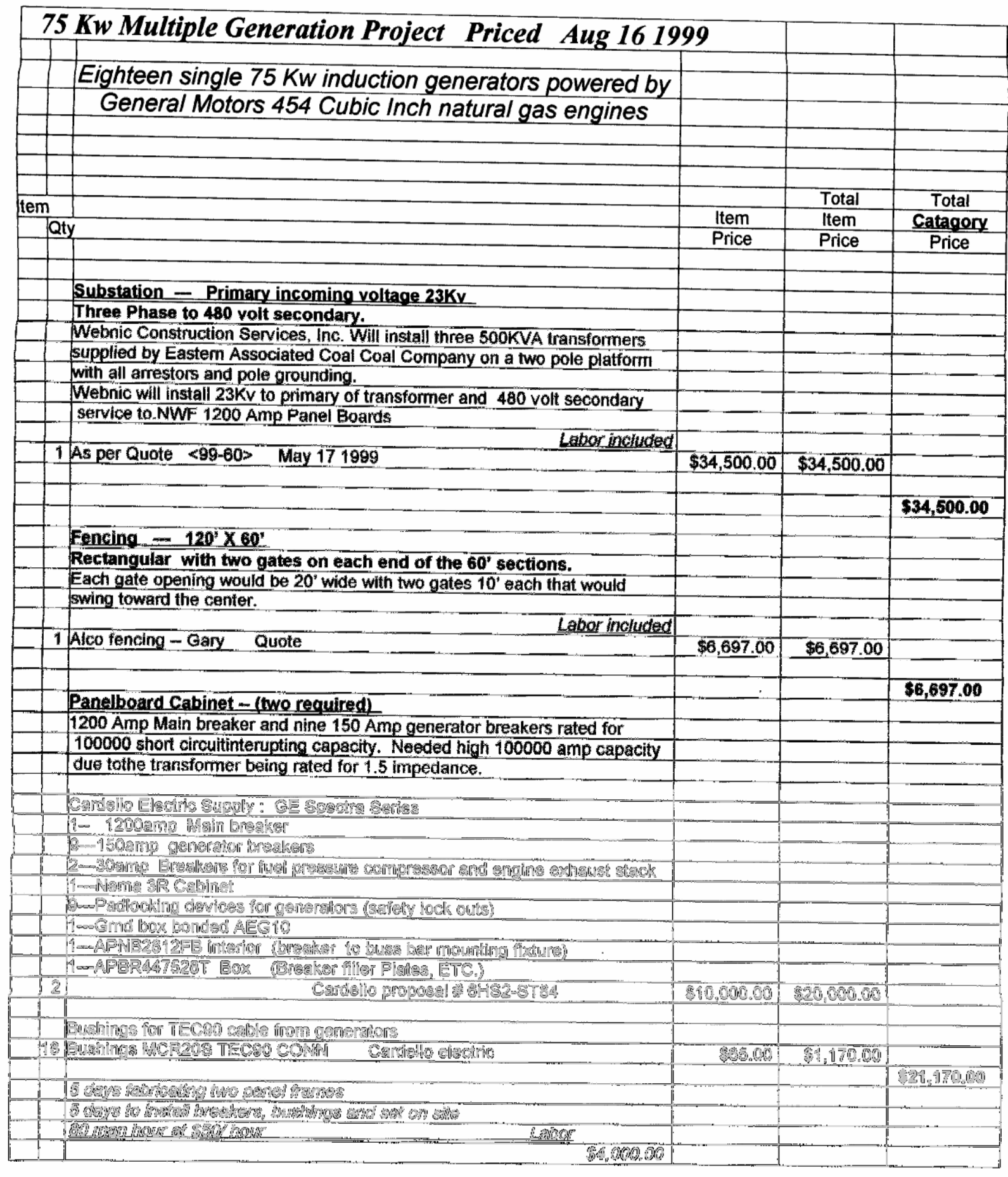




\begin{tabular}{|c|c|c|c|c|c|}
\hline & & Control / Utility Transformer and Panelboard & & & \\
\hline & & $\begin{array}{l}\text { Control/ Utility Transformer and Panelboard } \\
- \text { Nema } 3 R \text { enclosed } 15 \text { Kva to step } 480 \text { volt to } 120 \& 240 \text { volt. } 120 \text { volt }\end{array}$ & & & \\
\hline & & $\begin{array}{l}\text { - Nema } 3 R \text { enclosed } 15 \mathrm{Kva} \text { to step } 480 \text { volt to } 120 \& 240 \mathrm{volt} .120 \mathrm{volt} \\
\text { needed to operate IEC contactors and maintenance }\end{array}$ & & & \\
\hline & & & & & \\
\hline & & Cardello Electric Supply: Proposal \# 6H2-ST866 & & & \\
\hline 1 & 1 & \begin{tabular}{|l} 
\\
Cardello Electric Supply: Proposal \# 6H2-ST866 \\
GE 9T21B9105 15KVA 115C Rise 1Ph 480 TO 120/240
\end{tabular} & $\$ 480.00$ & $\$ 480.00$ & \\
\hline 2 & & $\begin{array}{|ll|}\text { GE } & 9 T 21 B 9105 \text { 15KVA 115C Rise 1Ph } 480 \text { TO 120/240 } \\
\text { GE } & \text { Panelboard Type AQ (101) 100amp Main 12Ckts } \\
\end{array}$ & & & \\
\hline & 1 & $\begin{array}{l}\text { GE Panelboard Type AQ (101) 100amp Main 12CKtS } \\
\text { eight } 20 \text { amp breakers, AB253 Box, AQF1121AB interior }\end{array}$ & $\$ 379.00$ & $\$ 379.00$ & \\
\hline & & & & & \\
\hline & & 6 days frabricate mount, install transformer and control voltage panel box & & & $\$ 859.00$ \\
\hline & & $48 \mathrm{man}$ hours at $\$ 50.00 / \mathrm{Hr}$ Labor & & & \\
\hline & & $\$ 2,400.00$ & & & \\
\hline & & & & & \\
\hline & & & & & \\
\hline & & Cenerator control Cabinat & & & \\
\hline & & Caneratar control cabing & & & \\
\hline & & Fault or by a manual safoty shut down button. & & & \\
\hline & & Enclosure NEMA 3R $48^{5 \times 2} \times 4^{*} \times 12^{2}$ Dwsp & & & \\
\hline 1 & 1 & PEC pricing & 8600,00 & $\$ 800.00$ & \\
\hline & & & & & \\
\hline & & & & & \\
\hline & & & & & \\
\hline & & & & & \\
\hline 2 & & Push bution antekn & & & \\
\hline & 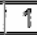 & Start: Grainger: Push button 58372 & 34.8.85 & $\$ 48.85$ & \\
\hline & $\overline{1}$ & i) Block bes30 & 88,48 & 98.48 & \\
\hline & 1 & 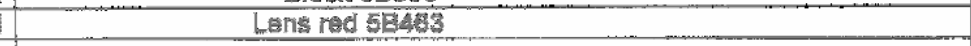 & 84,30 & $\$ 4.38$ & \\
\hline & & & & & \\
\hline 3 & & Sefety stop & & & \\
\hline & 1 & Push button 68330 & $\$ 34.55$ & $\$ 34.55$ & \\
\hline & 1 & Block 50535 & 38.46 & 38.48 & \\
\hline 4 & & Plot Liaht & & & \\
\hline & 1 & Yollow power on Grainger: 5 E520 & $\$ 4.95$ & 54.95 & \\
\hline & 1 & lens yellow 5B435 & 34.38 & 34,36 & \\
\hline & & & & & \\
\hline 5 & & Control volfage contactor: 4pole, Fuff load amps 30,120 volt hoiding coll & & & \\
\hline & 1 & Grainger $5 \mathrm{~B} 115$ & $\$ 33.50$ & $\$ 33.50$ & \\
\hline & & & & & \\
\hline 8 & 1 & 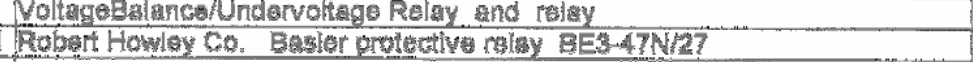 & 516900 & \$160.00 & \\
\hline 7 & 1 & & $8=50$ & & \\
\hline & 1 & Grainger Relay DPDT 120vold coll $5 \times 227$ & 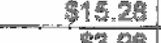 & $\$ 15.28$ & \\
\hline & & & 33.96 & 53.96 & \\
\hline & & Motering for utllity (aroduction and consumplion) & & & \\
\hline & 1 & AEP CAs Pts and metering davices Quote $7 / 28190$ & $\$ 1,500,00$ & $\$ 1,500.00$ & $2,47.77$ \\
\hline & & & & & \\
\hline & & 10 days Frabricate box mounting, installation of hardware and set-up on site & & & \\
\hline & & Do man haves/ $5 \%$ & & & \\
\hline & & $\$ 4,000,00$ & & & \\
\hline & & & & & \\
\hline & & & & & \\
\hline & & & & & \\
\hline
\end{tabular}




\begin{tabular}{|c|c|c|c|c|c|}
\hline & & & & & \\
\hline & & Gas Blower-Compressor 9.0 PSIA in 21 PSIA out & & & \\
\hline & & GL Sales Hunting Beach Ca. Tuthill Corp. Model 5511 Date 7/2/99 & & & \\
\hline & 1 & 5511-81LZE W/60HP TEFC & $\$ 11,115.00$ & $\$ 11,115.00$ & \\
\hline & & & & & \\
\hline & & Pressure control regulator & & & \\
\hline & 1 & Equimeter 2" model 121-12 with Green spring control 6-14" H2 O press. & $\$ 934.00$ & $\$ 934.00$ & \\
\hline & & & & & \\
\hline & & Electric motor starter for Tuthill $60 \mathrm{HP}$ & & & \\
\hline & & Nema size three $10 \mathrm{G} 1$, Start/stop button $480 \mathrm{v} / 480 \mathrm{v}$ control three heaters to & & & \\
\hline & & control overload CR123F567B Nema 3Renclosure & & & \\
\hline & 1 & Cardello Quote 6H2-CW5371 & $\$ 1,895.00$ & $\$ 1,895.00$ & \\
\hline & & Fuses for starter Cardello LTLFLSR200ID & $\$ 32.88$ & $\$ 98.64$ & \\
\hline & & & & & \\
\hline & & Wiring for 60HP Tuthill Model 5511-81LZE & & & \\
\hline & & 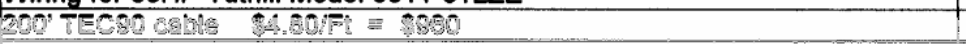 & $\$ 980.000$ & SR80,00 & \\
\hline & & Bushwosfor oaldeMCR20S TECoO Conn & 889.00 & $\$ 130.00$ & \\
\hline & & & & & \\
\hline & & & & & \\
\hline & & 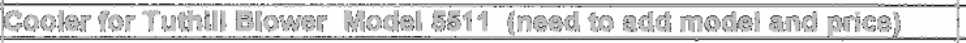 & 36.00 & & \\
\hline & & & & & 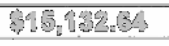 \\
\hline & & 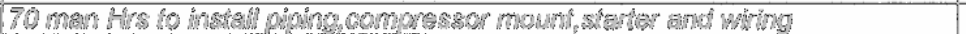 & & & \\
\hline & & 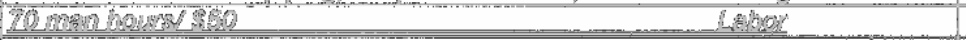 & & & \\
\hline & & $83,500.00$ & & & \\
\hline & & & & & \\
\hline & & & & & \\
\hline & & Sas rogulator: & & & \\
\hline & & Worth Hollyweod Ca., & & & \\
\hline & 2. & 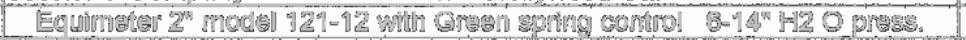 & $\operatorname{sg} 34.00$ & 30.68 .00 & \\
\hline & & Wiog unions & 318,79 & P100.89 & \\
\hline & & 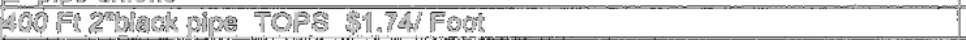 & (58g.00. & 30.001 & \\
\hline & 40 & 20 ofollil black Irom & 3.68 & (5. & \\
\hline & 22 & 26 blad Iron tag & 35.72 & 8125.44 & \\
\hline & 18 & $2^{x}$ - j" raducing busiña & 2.85 & 847.70 & \\
\hline & 2018 & 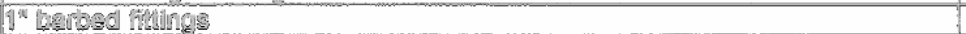 & 82.78 & 9000.44 & \\
\hline & 39 & 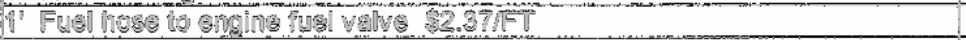 & 92.37 & Mes.2. & \\
\hline & & & & & $3,003,7 \%$ \\
\hline & & & & & \\
\hline & & & & & \\
\hline & & 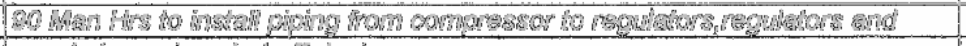 & & & \\
\hline & & 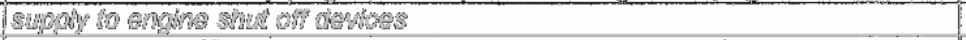 & & & \\
\hline & & 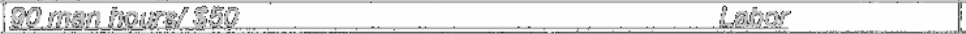 & & & \\
\hline & & $\$ A, 500,09$ & & & \\
\hline & & & & & \\
\hline & &  & & & \\
\hline & & 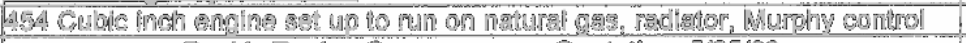 & & & \\
\hline & 19 & 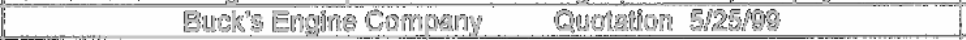 & Q4, 150,00: & $374,180.00$ & \\
\hline & & 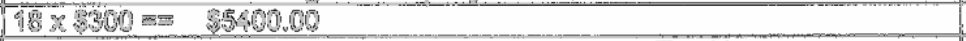 & & & 87. 19000 \\
\hline & & Bandors: & & & \\
\hline & & 3506,06 & & & \\
\hline & & & & & \\
\hline & & 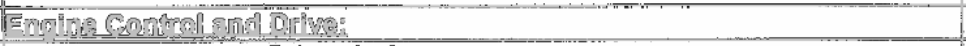 & & & \\
\hline & & 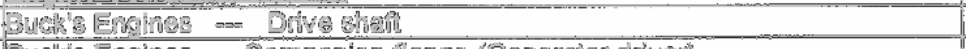 & 8150.00 & Q. & \\
\hline 2. & & 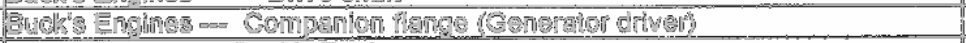 & 175. & $53,150.601$ & \\
\hline 3 & 18 & 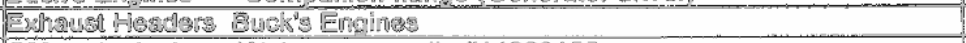 & \$150.00 & $92,700.00$ & \\
\hline A & $\sqrt{108}$ & 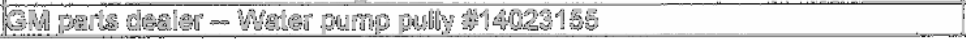 & 830, 19 & 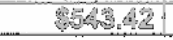 & \\
\hline
\end{tabular}




\begin{tabular}{|c|c|c|c|c|}
\hline 5 & 18 Fabricate idler Bracket NWF shop & $\$ 50.00$ & $\$ 900.00$ & \\
\hline 6 & 18 Idler pully Napa 209847 & $\$ 15.97$ & $\$ 287.46$ & \\
\hline 7 & 18 Belt Napa & $\$ 6.75$ & $\$ 121.50$ & \\
\hline 8 & 18 Over flow reserve for radiator Napa & $\$ 11.50$ & $\$ 207.00$ & \\
\hline 9 & 18 Tachometer/over speed control Murphy DT 9805 & $\$ 325.00$ & $\$ 5,850.00$ & \\
\hline 10 & 18 Magnetic pick up (for Tach) Murphy MP 3298 & $\$ 45.00$ & $\$ 810.00$ & \\
\hline 11 & 18 Engine Hour meter 12 volt Murphy 00-00-0865 & $\$ 40.00$ & $\$ 720.00$ & \\
\hline 12 & 18 Vibration control $\quad$ Murphy VS2 & $\$ 90.00$ & $\$ 1,620.00$ & \\
\hline 13 & 18 Electrical control (for oil level and tach) Murphy PH221 & $\$ 26.50$ & $\$ 477.00$ & \\
\hline 14 & 18 Oil level controller $\quad$ Murphy LR857FP & $\$ 88.50$ & $\$ 1,593.00$ & \\
\hline 15 & 18 Natural gas, pressure operated shut in valve Murphy M2582P & $\$ 185.00$ & $\$ 3,330.00$ & \\
\hline 16 & 18 Exhaust headers (exit through roof design) Buck's Engine & $\$ 150.00$ & $\$ 2,700.00$ & \\
\hline 17 & 18 Clutch saftey switch Grainger $3 \times G 60$ & $\$ 33.80$ & $\$ 608.40$ & \\
\hline 18 & 18 Oil cooler Grainger 4F362 & $\$ 276.00$ & $\$ 4,968.00$ & \\
\hline 19 & 18 Fittings cooler $5 / 8$ barb-1/2pipe Napa BK1660-1528 $\$ 4.77$ ea-- 6 per engine & $\$ 28.62$ & $\$ 515.16$ & \\
\hline 20. & 19 Renote mer how & 616.57 & 39.22.25 & \\
\hline 21 & 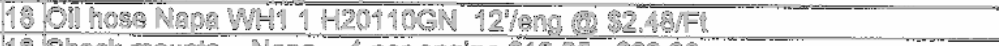 & 2.98 & 655.68 & \\
\hline & 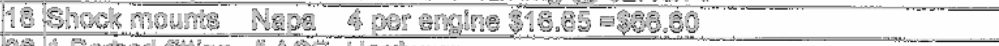 & 88.80 & 84.189.89 & \\
\hline & 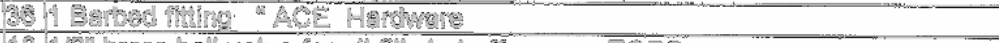 & 279 & 100.64 & \\
\hline & $181 / 2$ brass bell value for of mil shut of & (6. 65 & 105.48 & \\
\hline & 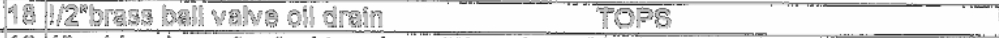 & 35.06 & 10s, 40 & \\
\hline & 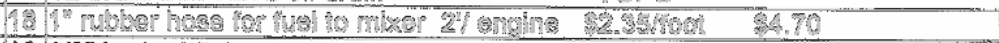 & 34.70 & 32,80 & \\
\hline & 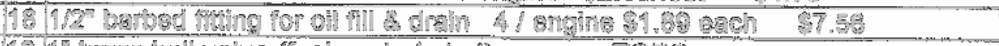 & 37.53 & 90.0. & \\
\hline & 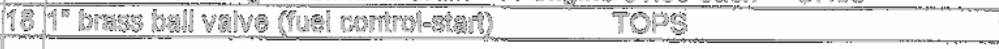 & 10.85 & 8985.30 ? & \\
\hline & & & & 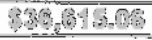 \\
\hline & 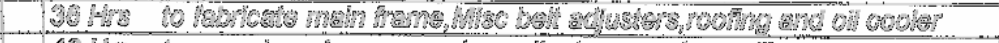 & & & \\
\hline & 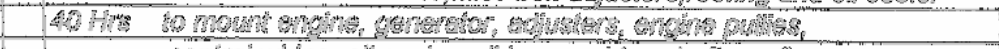 & & & \\
\hline & 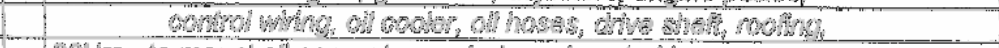 & & & \\
\hline & 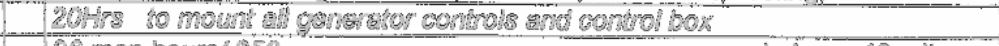 & & & \\
\hline & 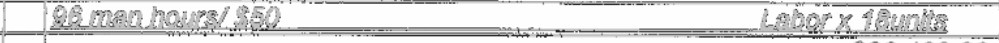 & & & \\
\hline & $300,400,00$ & & & \\
\hline & & & & \\
\hline & & & & \\
\hline & 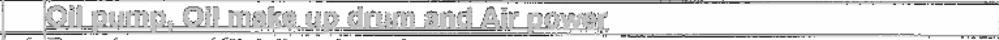 & & & \\
\hline & 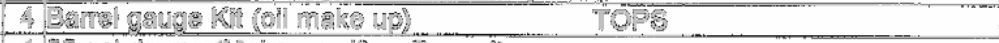 & $\$ 110.06$ & \$40.00 & \\
\hline & 4.55 gal drums Malke up oll Deposh & 920.00 & 00.00 & \\
\hline & 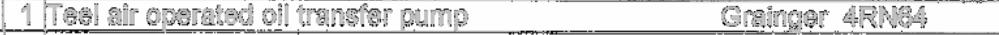 & 89800 & \$46.,00 & \\
\hline & 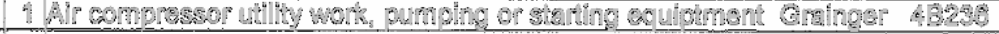 & 649.00 & $\$ 4.9 .00$ & \\
\hline & & & & 31,69768 \\
\hline & 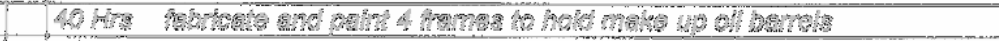 & & & \\
\hline & 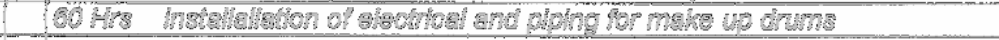 & & & \\
\hline & & & & \\
\hline & 100 monvones & & & \\
\hline & $96,600,02$ & & & \\
\hline & & & & \\
\hline 1 & 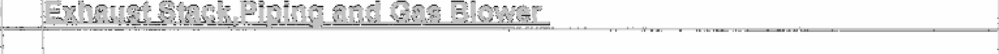 & & & \\
\hline 2 & LAP, Ine, Model 2 GSB & & & \\
\hline & 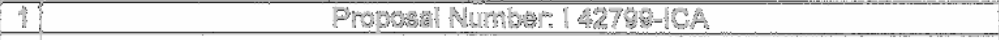 & $96,635.00$ & 66.855 .00 & \\
\hline & & & & \\
\hline$(5$. & 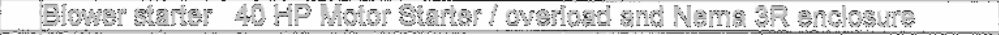 & & & \\
\hline & 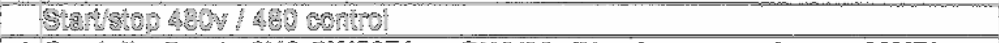 & & & \\
\hline & 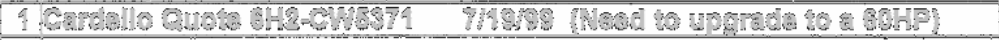 & 91.65500 & $14,585.60$ & \\
\hline & 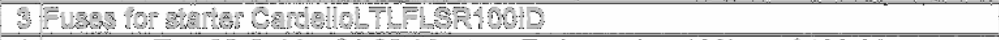 & 698.48 & 39.29 & \\
\hline & 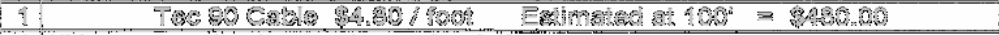 & \$480,0 & 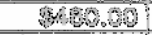 & \\
\hline 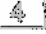 & 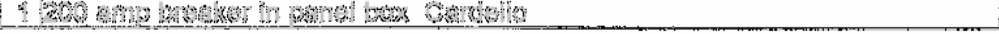 & 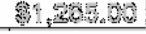 & $80,90.001$ & \\
\hline
\end{tabular}




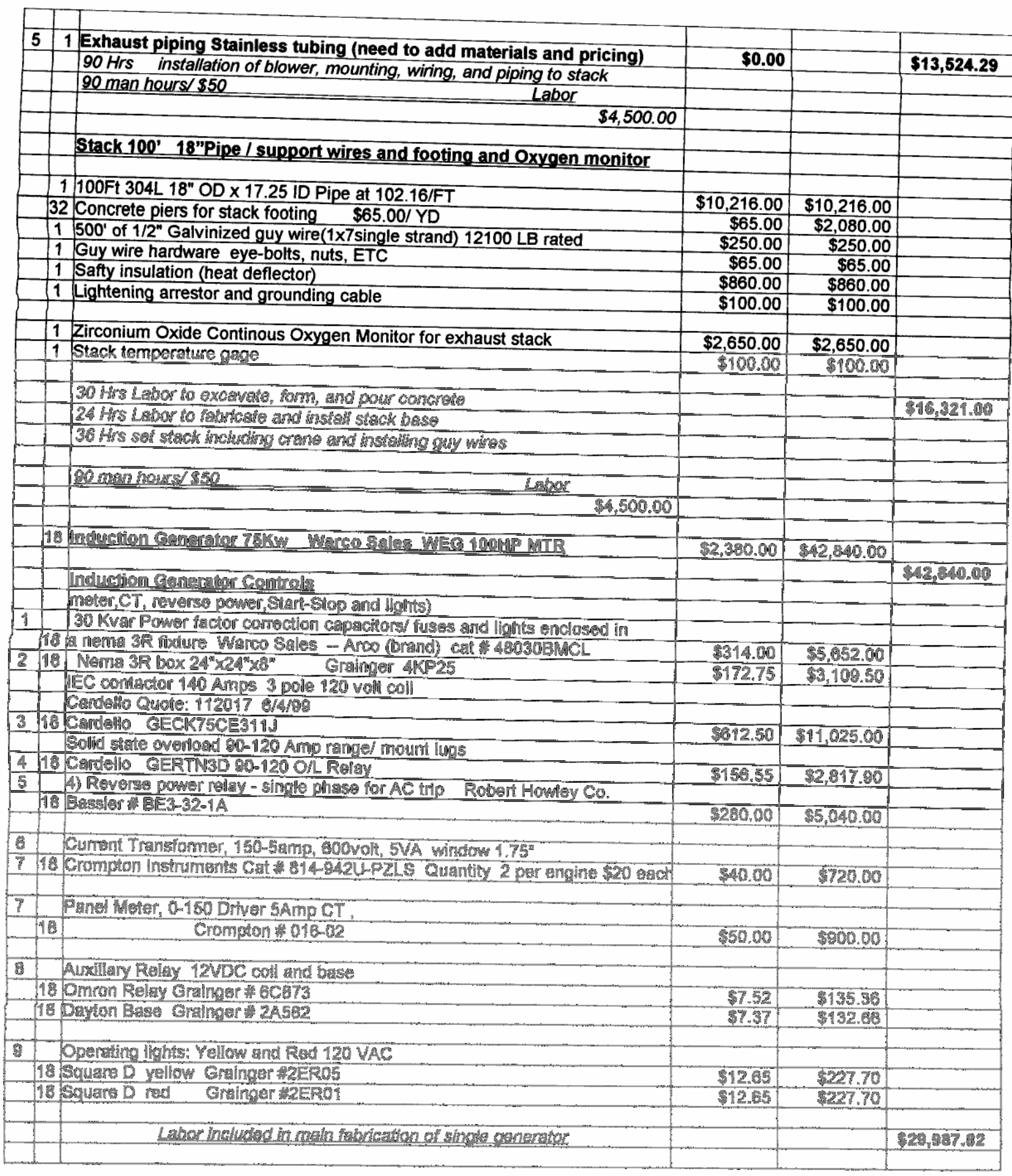




\begin{tabular}{|c|c|c|c|c|c|}
\hline & & & & & \\
\hline & & Wire between 150Amp Breaker Panel and Generator Control & & & \\
\hline & & & & & \\
\hline 1 & & Cardello TEC90103 WG 3C 1/0 W/G Quote\# $113410 \quad 7 / 01 / 99$ & & & \\
\hline & 1 & Tec 90 Cable $\$ 4.80 /$ foot Estimated at $954^{\prime}=\$ 457920$ & $\$ 4,579.20$ & $\$ 4,579.20$ & \\
\hline & & & & & \\
\hline 2 & & Bushings for cable into generator control box & & & \\
\hline & 18 & Cardello MCR20S TEC90 CONN & $\$ 65.00$ & $\$ 1,170.00$ & \\
\hline & & Quote\# $113410 \quad 7 / 01 / 99$ & & & \\
\hline & & & & & $\$ 5,749.20$ \\
\hline & & & & & \\
\hline & & Labor included on installation at site & & & \\
\hline & & & & & \\
\hline & & & & & \\
\hline & & Gas Pipeline & & & \\
\hline & & 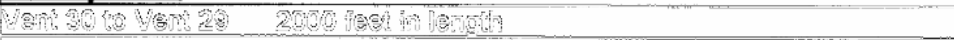 & & & \\
\hline & & 2960 ? & & & \\
\hline & & 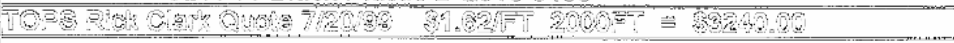 & $\sqrt{2} 600$ & (2), 4006 & \\
\hline & & & & & \\
\hline & & 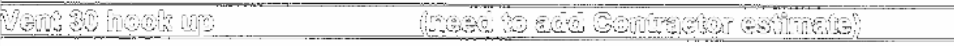 & Q6. & & \\
\hline & & & & & \\
\hline & & 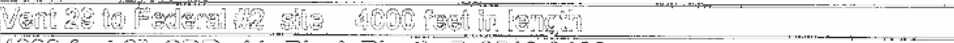 & & & \\
\hline & & 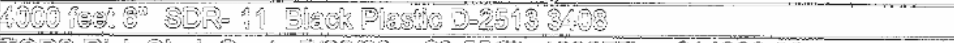 & & & \\
\hline & & 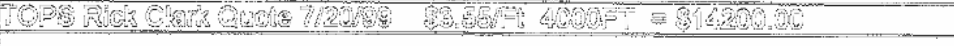 & 04200 & 916,2000 & \\
\hline & & & & & 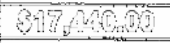 \\
\hline & & 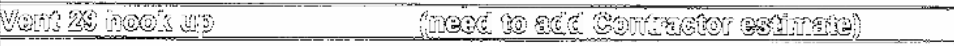 & SOS & & \\
\hline & & $: \cdots$ & & & \\
\hline & & 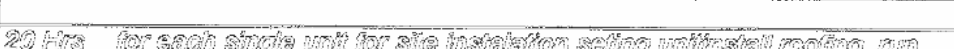 & & & \\
\hline & & 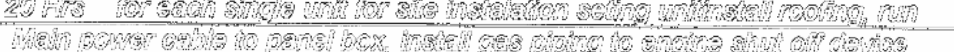 & & & \\
\hline & & 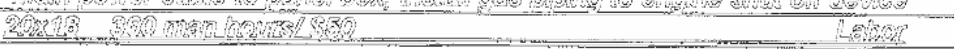 & & & \\
\hline & & vingoson & & & \\
\hline & & & & & \\
\hline & & & & & \\
\hline & & 7 monge & & & \\
\hline & & 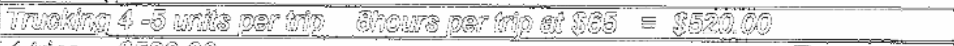 & & & \\
\hline & & 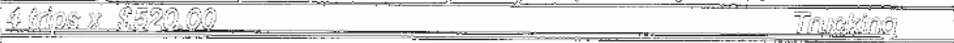 & & & \\
\hline & & $5: 200.60$ & & & \\
\hline & & & & & \\
\hline & & & & & \\
\hline & & & & & \\
\hline & & 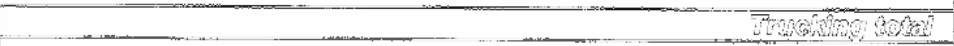 & G. 60,0 & & \\
\hline & & & & & \\
\hline & & 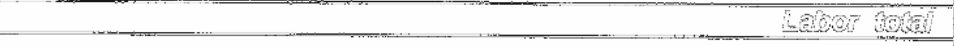 & 616220000 & & \\
\hline & & & & & \\
\hline & & materges forn & & Baring & 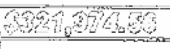 \\
\hline & & & & & \\
\hline & & Hoo, & N196. & & \\
\hline
\end{tabular}


APPENDIX D

SOURCE EMISSION TESTS: NOX AND CO2 


\section{MONARCH}

ANALYTICAL LABORATORIES. INC.

349 TOMAHAWK DR. - MAUMEE. OH 43537-1696

PHONE (419) 897.9000 - FAX (419) 897.9111

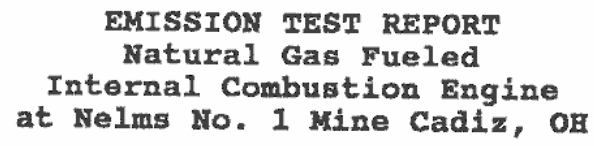

REQUEST MO: COM-98-E-0753

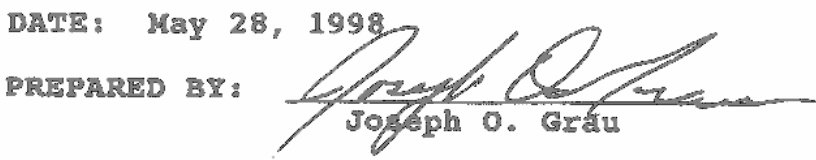

$8.9 / \mathbb{E}=0753$ 


\section{SUMMARY}

\subsection{EMISSIONS}

A summary of the emission results is provided below. Refer
to Table 1 for more detailed information.

Test No.

Oxides of Nitrogen

\section{(ppm)}

(3) (3)

Carbog Rourside

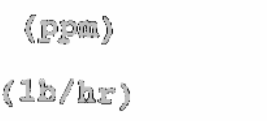

1

2462

2.93

329

0.24
2

27 송응

3. 3 .

325

0.25
3

2674

3.20

326

0.28
Average

2627

3.21

327

0.24 